Ananda Brito de Assis

Análise sobre a microbiota cutânea de anfíbios em fragmentos de Floresta Atlântica e sua eficácia contra agentes patogênicos

Analysis on the bacterial microflora on the amphibian skin of Atlantic Forest fragments and its effectiveness against pathogens

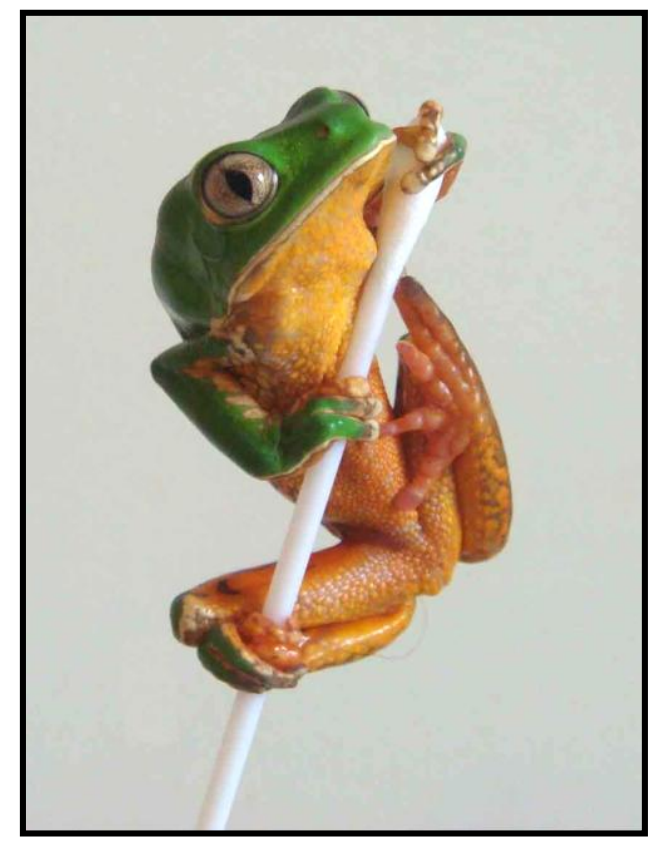

São Paulo 
Ananda Brito de Assis

\title{
Análise sobre a microbiota cutânea de anfíbios em fragmentos de Floresta Atlântica e sua eficácia contra agentes patogênicos
}

\author{
Analysis on the bacterial microflora on the amphibian skin of Atlantic \\ Forest fragments and its effectiveness against pathogens
}

Dissertação apresentada ao Instituto de Biociências da Universidade de São Paulo, para a obtenção de Título de Mestre em Ciências, na Área de Fisiologia Geral.

Orientador: Prof. Dr. Carlos Arturo Navas Iannini

Co-orientadora: Prof ${ }^{\mathrm{a}}$. Dr ${ }^{\mathrm{a}}$. Cristine Chaves Barreto

Versão corrigida.

Original encontra-se disponível no Instituto de Biociências.

\section{São Paulo}


Assis, Ananda B.

Análise sobre a microbiota cutânea de anfíbios em fragmentos de Floresta Atlântica e sua eficácia contra agentes patogênicos

103 páginas

Dissertação (Mestrado) - Instituto de Biociências da Universidade de São Paulo. Departamento de Fisiologia.

1. Anura 2. Microbiota cutânea 3. Ambiente

I. Universidade de São Paulo. Instituto de Biociências.

Departamento de Fisiologia Geral.

\section{Comissão Julgadora:}

$\operatorname{Prof}(a) . \operatorname{Dr}(a)$.

$\operatorname{Prof}(a) . \operatorname{Dr}(a)$.

Prof. Dr.

Orientador 
À minha família, meu sustentáculo. 
"A mais profunda emoção que podemos experimentar é inspirada pelo senso do mistério. Essa é a emoção fundamental que inspira a verdadeira arte e a verdadeira ciência." 


\section{Agradecimentos}

O trabalho aqui apresentado não poderia ter sido realizado sem a contribuição de diversas pessoas, que tiveram participação, direta ou indireta, do meu aprendizado e construção desta pesquisa. Sou grata ao meu orientador Carlos Arturo Navas Iannini e minha co-orientadora Cristine Chaves Barreto por terem acreditado e me acompanhado nesta pesquisa, desde o início até a elaboração deste manuscrito.

Agradeço ao Instituto de Biociências pela infra-estrutura e à Fundação de Amparo à Pesquisa do Estado de São Paulo, pela bolsa de mestrado concedida e financiamento.

Sou imensamente grata aos colegas do Laboratório de Ecologia Microbiana do Instituto Oceanográfico, que tem os cuidados da professora Vivian Helena Pellizari, especialmente à Carol, Priscila e Dani, por estarem sempre dispostas a tirar minhas eternas dúvidas relacionadas aos procedimentos em Microbiologia. Ainda neste laboratório, devo um agradecimento especial à Rosa, pela iniciação nesses procedimentos, disposição e estímulo.

Agradeço aos amigos do laboratório de Biologia Molecular, da Universidade Católica de Brasília, especialmente à Flávia por ter sido grande companheira nos estudos de comunidades microbianas, que não foram incluídos neste trabalho, mas que serviram de preparo para as etapas seguintes deste estudo. Esses procedimentos foram realizados no Laboratório de Fisiologia de Tripanossomatídeos e sou grata à professora Lucile Floeter-Winter, por ter cedido o espaço e pelas orientações nas metodologias utilizadas. Sou imensamente grata ao Ricardo Zampieri, pelo aprendizado, ajuda e paciência durante os procedimentos. Assim como aos demais colegas sempre tão prestativos: Marcos, Fernanda e Ermeson. 
Sou grata aos amigos do laboratório do qual faço parte: Fisiologia Ecológica e Evolutiva, por fazerem parte da minha formação como cientista, durante as estimulantes discussões, especialmente ao Pedro Ribeiro, pelas sugestões para o manuscrito e à Lye pelas aventuras no campo. Sou também grata pela amizade e predisposição em ajudar uns aos outros, características marcantes dessas pessoas.

Agradeço à Roseli por estar sempre disposta a nos auxiliar nas eternas burocracias acadêmicas e à Gisele, por fazer das burocracias acadêmicas e administrativas problemas simples e dissolúveis. Um agradecimento especial ao Be, pelo imensurável companheirismo e amizade durante e depois dos trabalhos de campo e à Telma pelo auxílio na manutenção das cepas e auxílio nos procedimentos no laboratório.

Por fim, tenho também grande gratidão a pessoas que não contribuíram diretamente nesta pesquisa ou aprendizado científico e acadêmico, mas indiretamente, pelo simples e complexo fato de fazerem parte de minha vida: minha enorme família, especialmente meu pai Fernando, mãe Marina e meus irmãos Alden e Mayan. Sem faltar minha tia Rosenilda, que é tão parceira em minha estadia em São Paulo e o Marcus, por todo companheirismo e carinho. 


\section{Sumário}

Introdução Geral.

Capítulo 1. Análise sobre a densidade de microbiota cutânea de quatro espécies de anfíbios: Proceratophrys boiei (Anura, Cicloramphidae), Dendropsophus minutus, Aplastodiscus leucopygius e Phyllomedusa distincta (Anura, Hylidae), em paisagens contínuas e fragmentadas de Floresta Atlântica...........................................06

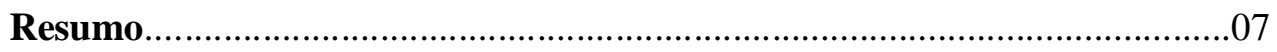

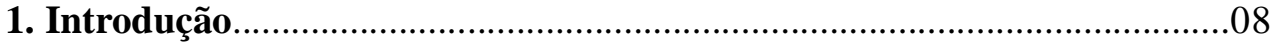

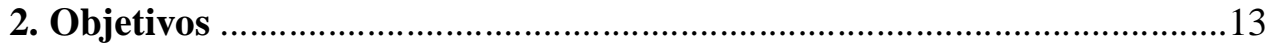

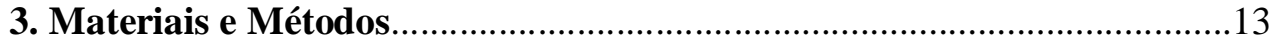

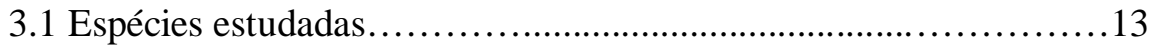

3.2 Áreas de estudo.......................................................................14

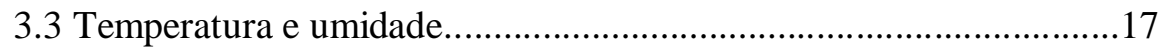

3.4 Microbiologia em campo............................................ 17

\section{Resultados}

4.1 Coleta dos espécimes...................................................................21

4.2 Densidade de colônias bacterianas ...................................................22

4.3. Análises de temperatura e umidade.......................................29

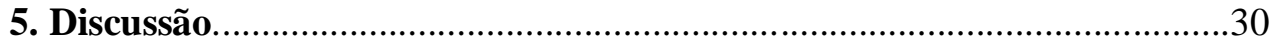

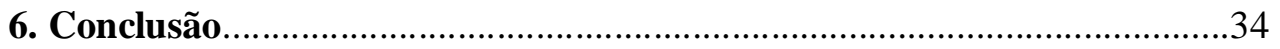

Capítulo 2. Caracterização da microbiota cutânea de quatro espécies de anuros em diferentes fragmentos de Floresta Atlântica: Riqueza e

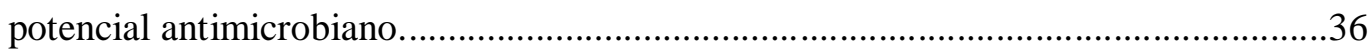

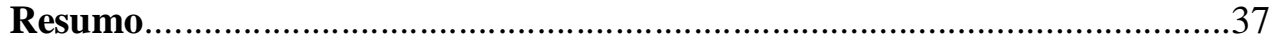

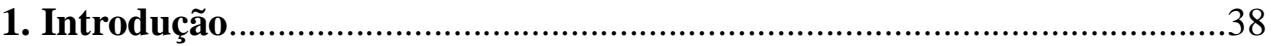

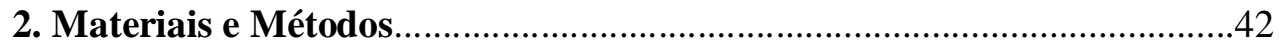

2.1Isolamento dos morfotipos de colônias bacterianas............................42

2.2 Inibição de crescimento bacteriano................................................43

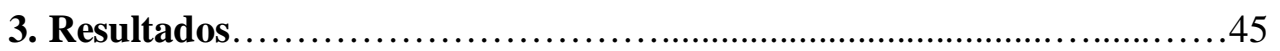

3.1. Morfotipos........................................................ 45

3.2. Densidade de morfotipos.............................................. 46 
3.3. Ensaio de poder inibitório de patógenos...........................................48

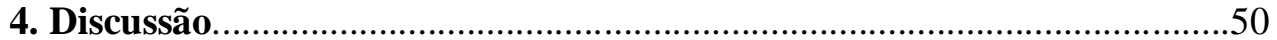

4.1 Riqueza microbiana......................................................................50

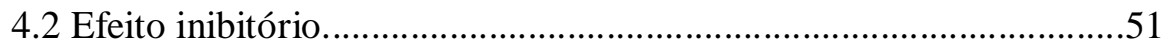

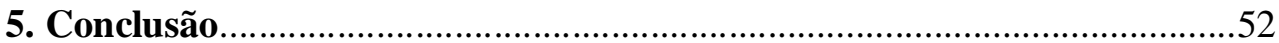

Capítulo 3. Identificação de morfotipos de colônias bacterianas isoladas de comunidades microbianas residentes da pele de quatro anuros da

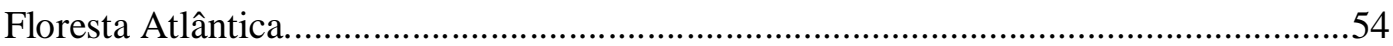

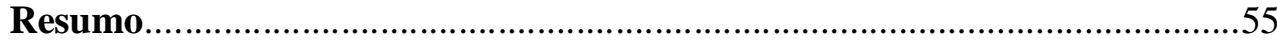

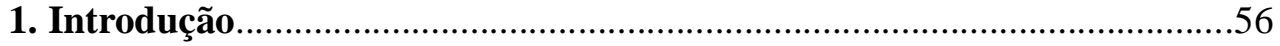

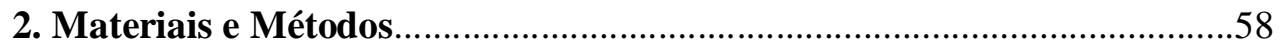

2.1 Identificação dos isolados....................................................58

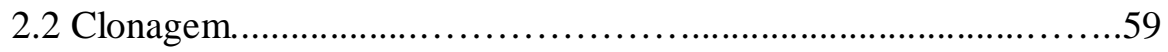

2.3.Determinação da seqüência de nucleotídeo e análise

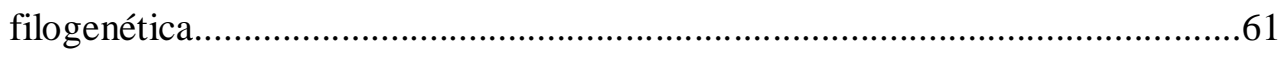

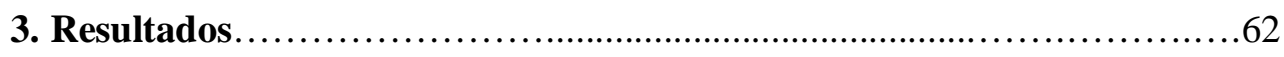

4. Discussão

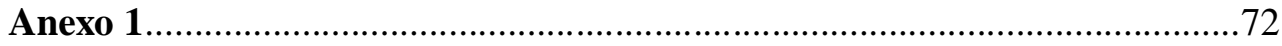

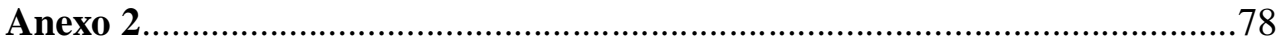

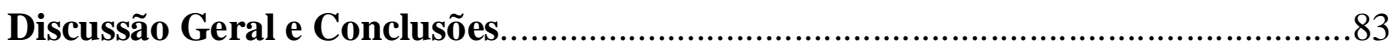

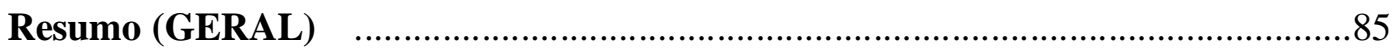

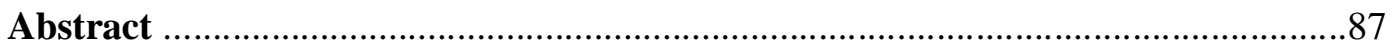

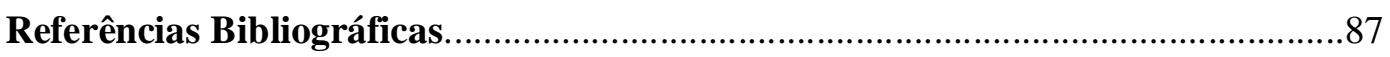


Introdução Geral 


\section{Declínios de populações de anfíbios}

Nas últimas décadas diversas populações de anfíbios têm sofrido declínio e extinção local, ou total em alguns casos. (Heyer et al., 1988; Echegaray \& Hernando, 2004; Eterovick et al., 2005; Lips, et al., 2005; La Marca et al., 2005; Carey \& Alexander, 2003; Keisecker et al., 2001; Funk \& Mills, 2003; Carey et al., 1999; Rollins-Smith et al., 2002; Alexander \& Eischeid, 2001; Lips et al., 2006; Mendelson III et al., 2006; Pouds et al., 2006). Nesse período, pelo menos $43 \%$ das espécies de anfíbios tem sofrido declínio, $32.5 \%$ estão globalmente ameaçadas, 34 foram extintas e 88 estão passíveis ou possivelmente estão extintas (Lips et al. 2006). No Brasil, 20 espécies de anfíbios anuros parecem estar sofrendo declínio em suas populações, sendo que duas destas espécies ocorrem no Bioma Cerrado e todas as demais na Floresta Atlântica (Eterovick et al., 2005). Muitos casos de declínio populacional em anfíbios estão relacionados às ocorrências de novos patógenos (Carey et al., 1999; Schumacher, 2006). Por isso, o termo Emerging Infectious Diseases (EIDs), antes usado apenas para se referir a doenças humanas deflagradas em larga escala geográfica, agora é aplicado também à vida selvagem, fazendo alusão à série de epidemias constatadas no meio natural nestes últimos anos (Daszak et al., 2001).

O fungo quitrídio Batrachochytrium dendrobatidis é indicado como o principal agente envolvido nos casos de declínios de populações de anfíbios em diversas partes do mundo e já foi detectado em algumas comunidades de anfíbios no Brasil. As primeiras menções desse fungo em populações de anfíbios na Floresta Atlântica datam de 1981 e, segundo Carnaval et al. (2006), estariam relacionados aos primeiros registros de declínios populacionais em território brasileiro. 


\section{O cenário ambiental}

As populações selvagens de anfíbios podem estar mais susceptíveis aos patógenos se modificações em variáveis físicas do ambiente está relacionada com eventos de doenças. Um exemplo bem estudado é a diminuição nos valores médios de parâmetros do sistema imune, tais como células de defesa, quando animais são expostos a pesticidas. Neste caso, os indivíduos se tornam mais vulneráveis às infecções por patógenos presentes naturalmente no ambiente e a sobrevivência de toda uma população pode ser comprometida (Christin et al., 2004; Raffel et al. 2006; Vos et al., 1989).

Mudanças ambientais de origem antropogênica nas áreas naturais podem contribuir para o estabelecimento de um cenário propício à disseminação de doenças em grande escala. Destacam-se as mudanças climáticas, aumento da incidência de radiação ultravioleta (UV-B), introdução de espécies exóticas e competidoras, contaminação por agentes tóxicos e fragmentação das áreas de mata que causam perda de hábitat e isolamento de populações (Keisecker et al., 2001; Blaustein \& Kiesecker, 2002; Echegaray \& Hernando, 2004). Nesse contexto, os anfíbios compõem um grupo considerado particularmente vulnerável a diversos tipos de impacto ambiental. Por isso, diversas variáveis bióticas e abióticas têm sido estudadas no contexto dos declínios populacionais desse grupo e alguns autores consideram a fragmentação de habitat como a principal causa de declínios populacionais de anfíbios, típicos de ambientes florestais (Saunders et al. 1991; Joly et al., 2003).

\section{As primeiras barreiras de proteção contra patógenos}

Os anfíbios possuem um sofisticado sistema imune e uma pele que atua com barreira inicial contra predadores e microorganismos patogênicos (Zasloff 2002). Além de secretar moléculas componentes de venenos, moléculas bioativas com ação antimicrobiana, 
essa superfície é continuamente umidificada por muco que pode ter um papel na termorregulação (Lillywhite, 1974). Em algumas espécies há também secreção de ceras liberadas por glândulas para prevenir a dessecação (Fontana et al., 2006).

Estudos sobre a microbiota cutânea de anfíbios apontam para um papel funcional de proteção contra patógenos. A primeira menção sobre microbiota cutânea na literatura data de 1986, no trabalho de Bettin \& Greven, com a espécie Salamandra salamandra. Após isso Austin (2000) também constatou a presença de uma comunidade microbiana residente sobre a pele da salamandra Plethodon ventralis. Nesse trabalho foi sugerido que antibióticos produzidos pelas bactérias componentes dessas comunidades poderiam prevenir a infecção fúngica dos ovos chocados pelas fêmeas (Austin, 2000). Assim, essas comunidades consistem de populações de microorganismos que são capazes de se multiplicar na pele e que podem inibir o crescimento de outros microorganismos seja pela produção de substâncias ou pela competição. Dessa forma, a compreensão da interação entre a microbiota cutânea e os agentes patogênicos, além dos fatores que ditam variações na sua composição, é importante no sentido de entendermos a contribuição dessas comunidades para a resistência ou susceptibilidade dos anfíbios às doenças infecciosas.

\section{Contextualizando o trabalho}

Os microrganismos são vulneráveis às alterações no substrato onde vivem, tais como temperatura, $\mathrm{pH}$, disponibilidade de água, nutrientes, entre outros (Madingan et al., 2004). Portanto, os microorganismos presentes na epiderme dos anuros, por sua vez exposta às alterações físicas, químicas e bióticas típicas dos remanescentes de Floresta Atlântica, podem ter a estrutura de suas comunidades alteradas. Além disso, é possível que características da história natural, por exemplo, o microhabitat ocupado por uma espécie de 
anfíbio também contribua para a determinação dos perfis das comunidades microbianas da pele.

Pela breve discussão realizada até o momento, podemos sugerir que 1) os anuros possuem uma microbiota residente na pele, 2) tal comunidade microbiana desempenha um papel importante contra a ação de patógenos, 3) essa comunidade pode ser afetada por variáveis associadas ao microhabitat e história natural de cada espécie e 4) tais considerações devem ser muito importantes no contexto de anuros de ambientes florestais fragmentados.

A presente pesquisa esteve focada em três frentes de trabalho simultâneas, que resultou na produção de três capítulos independentes. O primeiro trata sobre as densidades de bactérias cutâneas de quatro espécies de anuros: Proceratophrys boiei, Aplastodiscus leucopygius, Phyllomedusa distincta e Dendropsophus minutus, em dois contextos de paisagem: áreas contínua e fragmentada. Dessa forma, análises foram feitas sob as perspectivas da paisagem, espécie e localidade onde os animais foram coletados, sendo a discussão focada nesses aspectos e naqueles relacionados à história natural dessas espécies. O capítulo dois está focado na caracterização morfológica das entidades das comunidades amostradas na primeira parte do trabalho, que compõe o capítulo um, e nos experimentos realizados in vitro para a verificação do potencial de ação inibitória dessas entidades isoladas contra alguns patógenos conhecidos. No terceiro capítulo constam as identificações, por métodos moleculares, de parte das entidades bacterianas isoladas. Neste há também uma abordagem comparativa com táxons de bactérias isoladas de outras espécies de anfíbios, a partir de dados disponibilizados na literatura. 


\section{Capítulo 1}

Análise sobre a densidade de microbiota cutânea de quatro espécies de anfíbios: Proceratophrys boiei (Anura, Cicloramphidae), Dendropsophus minutus, Aplastodiscus leucopygius e Phyllomedusa distincta (Anura, Hylidae), em paisagens contínuas e fragmentadas de Floresta Atlântica 


\section{Resumo}

O potencial de bactérias isoladas das comunidades microbianas da pele de anfíbios, contra patógenos importantes como o fungo Batrachochytrium dendrobatidis tem sido verificado em estudos anteriores. Nesse aspecto, é indispensável o entendimento da estrutura e função dessas comunidades para as espécies de anfíbios, que têm experimentado eventos de declínio e extinção de populações, principalmente devido à destruição de habitat e à ocorrência de epidemias no meio natural. São desconhecidos os fatores que modulam a estrutura dessas microbiotas cutâneas, porém, o ambiente se perfila como componente fundamental na determinação dos perfis dessas comunidades. A densidade é um dos componentes principais dos ecossistemas microbianos e pode ser um bom norteador nesse momento inicial de pesquisa, onde buscamos entender de que maneira o ambiente modula as microbiotas cutâneas dos anfíbios. O objetivo geral dessa pesquisa foi a identificação dos padrões de densidade microbiana cutânea de quatro espécies de anfíbios, tanto sob a perspectiva das espécies quanto da paisagem onde os indivíduos estão inseridos. Foram coletados indivíduos em áreas contínuas e fragmentadas de Floresta Atlântica e nossos resultados mostraram que existem diferenças entre as espécies e entre as paisagens. Sendo P.boiei a espécie com a maior densidade microbiana, assim como os remanescentes de floresta, em contraposição às áreas contínuas. 


\section{Introdução}

A presença de comunidades microbianas sobre a pele dos anfíbios já foi constatada em trabalhos anteriores, assim como a caracterização de algumas bactérias como potentes inibidores do crescimento de patógenos importantes para esses animais (Harris et al., 2006; Woodhams et al., 2007; Lauer et al., 2007; Lauer et al., 2008; Culp et al., 2007; Brucker et al., 2008; Lam et al., 2009). É possível, portanto, que a microbiota cutânea desses animais atue como um componente fundamental de primeira proteção contra patógenos no meio natural. Apesar disso, não têm sido estudados os fatores que modulam os perfis dessas comunidades microbianas.

A partir de estudos prévios, não publicados, realizados por método Denaturing Gradient Gel Eletrophoresis (DGGE) observamos que o perfil das comunidades microbianas presentes sobre a pele de anfíbios sobrepunha parcialmente aquele das comunidades microbianas dos microhabitats ocupados pelos animais (Assis et al., não publicado). Culp et al., 2007 também detectaram a presença de entidades microbianas típicas de ambientes, como componentes das microbiotas cutâneas de três espécies de anfíbios. Dessa forma, podemos apontar o ambiente como um componente importante na colonização e composição das comunidades que se estabelecem sobre a pele dos anfíbios.

Os microrganismos podem ser fortemente afetados por mudanças nas condições de algumas variáveis químicas e físicas, principalmente temperatura, disponibilidade de água, pH e oxigênio, além de outros tais como pressão e radiação (Pelczar et al., 1981; Madigan et al., 2004; Madigan et al., 2009). Mesmo a pele dos animais não é um substrato constante, e pode variar conforme as condições ambientais, por exemplo, durante a termorregulação ou secreção de ceras para diminuir a perda de água e venenos para defesa 
(Daly, 1995). Assim, os perfis dessas comunidades microbianas poderiam ser influenciados pela condição do hospedeiro e o ambiente onde este se encontra.

\subsection{Fragmentação da paisagem e microbiota ambiental}

O processo de fragmentação é definido por Franklin et al., 2002 como "um conjunto de mecanismos que levam à descontinuidade a distribuição espacial dos recursos e condições presentes em uma área em uma dada escala que afeta a ocupação, reprodução e sobrevivência em espécies particulares" e, segundo Saunders e colaboradores, em 1991, altera as condições microclimáticas dentro e fora das áreas remanescentes, por meio de alterações nos valores médios e variâncias de diversos parâmetros físicos. Esse processo de perda de hábitat está entre as maiores ameaças às populações de anfíbios (Cushman, 2006).

Uma das variáveis que poderia afetar a microbiota cutânea dos anfíbios em remanescentes de floresta seria o aumento na incidência de radiação solar que alcança o solo dentro da mata. Esta por si só já muda a composição microbiana nesse substrato, assim como mudanças no regime termal local, com dias mais quentes e noites mais frias do que seria em áreas de floresta contínua (Saunders et al. 1991). O aumento da temperatura no solo afeta a ciclagem de nutrientes deste, o que afeta as suas comunidades microbianas (Plante \& Parton, 2007). Uma maior incidência de vento resulta em redução da umidade relativa e alteração nas características da superfície do solo devido ao aumento no folhiço pela maior queda de partes de vegetação. Gradientes drásticos dos níveis de nutrientes no solo são também formados, principalmente na área da borda da mata (Saunders et al. 1991). O fluxo de água é atingido pelo movimento de sais, nutrientes e pesticidas advindos das clareiras adjacentes e pode oferecer impactos significantes nos sistemas hídricos da área (Saunders et al. 1991). Uma vez que, parte da microbiota cutânea de alguns anfíbios é composta de bactérias de 
ambiente (Culp et al. 2007), esta deve ser afetada por consequiência das alterações acima mencionadas.

\subsection{Alterações na pele dos anuros, um substrato para a microbiota residente}

A pele dos anfíbios é um órgão de grande importância para as trocas gasosas, processo durante o qual a secreção de muco e a evapotranspiração atuam como mecanismos auxiliares (Lillywhite, 1974). Também é um órgão de defesa, feita por meio da secreção de venenos e moléculas antimicrobianas, que são parte do sistema imune inato (Rollins-Smith et al., 2005). É possível então perceber que a pele desses animais não é um substrato constante, no qual devem ocorrer mudanças de temperatura, $\mathrm{pH}$ e umidade. Isso nos faz pensar que a comunidade microbiana residente deve ser tolerante, ou mesmo adaptada a essas alterações naturais. A pele pode inclusive servir de substrato nutritivo, dada presença de carboidratos no muco, por exemplo, ou mesmo seletivo, devido aos peptídeos antimicrobianos (Brizzi et al., 2002; Rollins-Smith et al., 2005).

Mudanças nas características da pele dos anfíbios também podem ser consequiência das condições às quais os animais são expostos (Pelczar et al., 1981; Madigan et al., 2004), como aqueles cenários de impactos ambientais. Por exemplo, alguns dos peptídeos secretados pelas glândulas da derme são seqüestrados da dieta (Daly et al., 1995), por isso, alterações no tipo e disponibilidade de presas podem acarretar mudanças no perfil molecular das secreções (Daly et al., 1997). Além disso, a exposição a tóxicos e o aumento da radiação ultravioleta, que são alterados nos remanescentes (Saunders et al. 1991), podem também acarretar impactos sobre a microbiota cutânea dos anfíbios. Cabe ainda ressaltar a importância da temperatura, pois esta se configura como uma variável indispensável de se considerar ao falarmos sobre comunidades microbianas que habitam a superfície corpórea de 
animais ectotérmicos. Esses microrganismos, de fato, devem ser afetados pelos padrões termais corpóreos obtidos durante os eventos de termorregulação, nos quais as temperaturas corporais são determinadas pela interação com o microhabitat (Navas, 1996).

\subsection{Relevância da densidade microbiana}

A densidade microbiana é um fator importante na relação da comunidade residente com o seu hospedeiro e com eventuais patógenos com potencial para infeccioná-lo. Além disso, a densidade populacional de microrganismos sobre ou no interior de um organismo é muitas vezes determinante na deflagração de uma doença infecciosa (Madigan et al., 2009).

Em termos da microbiota cutânea de anfíbios, uma alta densidade microbiana residente, sobretudo das espécies bacterianas produtoras de antibióticos, poderia prevenir a infecção por patógenos através da pele. Lam et al., 2009 explicou a persistência de uma população de Rana mucosa pela alta proporção de indivíduos hospedando bactérias com potencial contra o fungo quitrídio $(B d)$, apesar da ocorrência desta na população. Em alguns casos, a densidade populacional é um fator determinante na biossíntese de compostos antimicrobianos. A produção da violaceína, um importante antibiótico produzido pela bactéria Chromobacterium violaceum, por exemplo, é densidade dependente sendo controlada por processo de comunicação microbiana que onde há sinalização para alterações na expressão gênica, de acordo com a densidade populacional (quorum sensing). Esse composto também é produzido por uma espécie de bactéria simbionte em espécies de salamandras e especula-se sobre a produção densidade dependente quando da infecção por Bd (Brucker et al., 2008). 


\subsection{Contexto da pesquisa}

A microbiota cutânea de anfíbios poderia ser afetada por mudanças ambientais às quais esses animais se expõem. Um cenário onde alguns parâmetros ambientais são, de forma constatada, alterados, é aquele dos remanescentes de Floresta Atlântica, produtos do processo de fragmentação de habitats. Nesse cenário, é possível que as alterações no macroambiente se estendam aos microhabitats ocupados pelos anfíbios. Nessas condições, a microbiota residente na pele desses animais pode ser afetada de forma direta pelos fatores ambientais, ou indireta, pelas mudanças fisiológicas às quais os animais ficam sujeitos, uma vez expostos às variações bióticas e abióticas típicas desses remanescentes. Temperatura e umidade são duas variáveis abióticas importantes no crescimento bacteriano e estabelecimento de comunidades sobre os substratos. Assim, poderiam afetar a comunidade microbiana residente da pele dos anfíbios tanto em condições naturais, como quando estes estão sujeitos a regimes de temperatura diferenciados, por exemplo, estando em paisagens fragmentadas. Um papel importante das condições macro e microambientais sobre a microbiota cutânea de anuros seria corroborado por nossa hipótese inicial: ao comparar as comunidades microbianas cutâneas de indivíduos representando espécies de anuros em paisagens contínuas de Floresta Atlântica e aqueles em paisagens fragmentadas desse mesmo bioma, e, além disso, ao comparar indivíduos ocupantes de microhabitats distintitos, existem diferencias, mesmo que a magnitude e direção das mesmas não poderiam ser previstas com a informação disponível. É provável que hajam diferenças entre paisagens contínuas e fragmentadas relacionadas às variáveis temperatura e umidade relativa. 


\section{Objetivos}

Para testar as hipóteses propostas determinamos como objetivo deste trabalho:

1.Estimar a densidade total de microbiota cutânea em populações de anuros provenientes de paisagens fragmentadas e contínuas de Floresta Atlântica.

2. Estimar a densidade bacteriana total em populações de anuros de diferentes espécies e microhabitats ocupados.

3. Caracterizar as áreas de estudo sobre as variáveis temperatura e umidade, em busca de relações entre esses fatores abióticos e os padrões de densidade microbiana cutânea total encontrados.

\section{Materiais e Métodos}

\subsection{Espécies estudadas}

Quatro espécies de anfíbios anuros adultos foram utilizadas neste trabalho: Proceratophrys boiei, família Cicloramphidae, Dendropsophus minutus, família Hylidae, Aplastodiscus leucopygius, família Hylidae e Phyllomedusa distincta, família Hylidae. As espécies representam microhabitats: Phyllomedusa distincta e Aplastpdiscus leucopygius como representantes do microhabitat vegetação (Bertoluci, 2005; Heyer, et al., 1990); Proceratophrys boiei que ocupa a serrapilheira do interior das matas (Zina et al., 2007) e Dendropsophus minutos mais relacionado a corpos de água e ambientes abertos (Pombal \& Haddad, 2005), ocupando o extrato arbóreo quando não está no sítio reprodutivo (Gomes, comunicação pessoal, 14 de março de 2011). Destas espécies, P.disticta consta na Red List como espécie não ameaçada, mas com populações em declínio, as demais possuem populações estáveis (IUCN, 2010). 


\section{2 Áreas de estudo}

Consideramos paisagens contínuas as florestas com grandes extensões de matas primárias que estão dentro das Unidades de Conservação e paisagens fragmentadas os remanescentes descontínuos de florestas. Foram determinadas duas grandes regiões para este estudo (Figura 1).

A primeira região compreende fragmentos de Floresta Atlântica situados no município de São Luís do Paraitinga, estado de São Paulo, entre a Serra da Mantiqueira e a Serra do Mar $\left(23^{\circ} 13^{\prime} S, 45^{\circ} 20^{\prime}\right.$ W). Paisagisticamente, é caracterizada, pela cobertura de matrizes de pastagens, cerca de 50,8\% sendo que os $11 \%$ de Floresta está distribuída na forma de pequenos e dispersos fragmentos (Becker, 2007). A paisagem contínua é uma área de floresta com 60\% de mata primitiva, com 17 mil hectares (Projeto de preservação da Mata Atlântica, 2007) localizados Núcleo Santa Virgínia (31' a $23^{\circ} 24^{\prime}$ S, $45^{\circ} 03$ a $45^{\circ} 11^{\prime}$ W), do Parque Estadual da Serra do Mar, situado, em grande parte, no município acima citado, além de Cunha e Ubatuba (Figura 2).

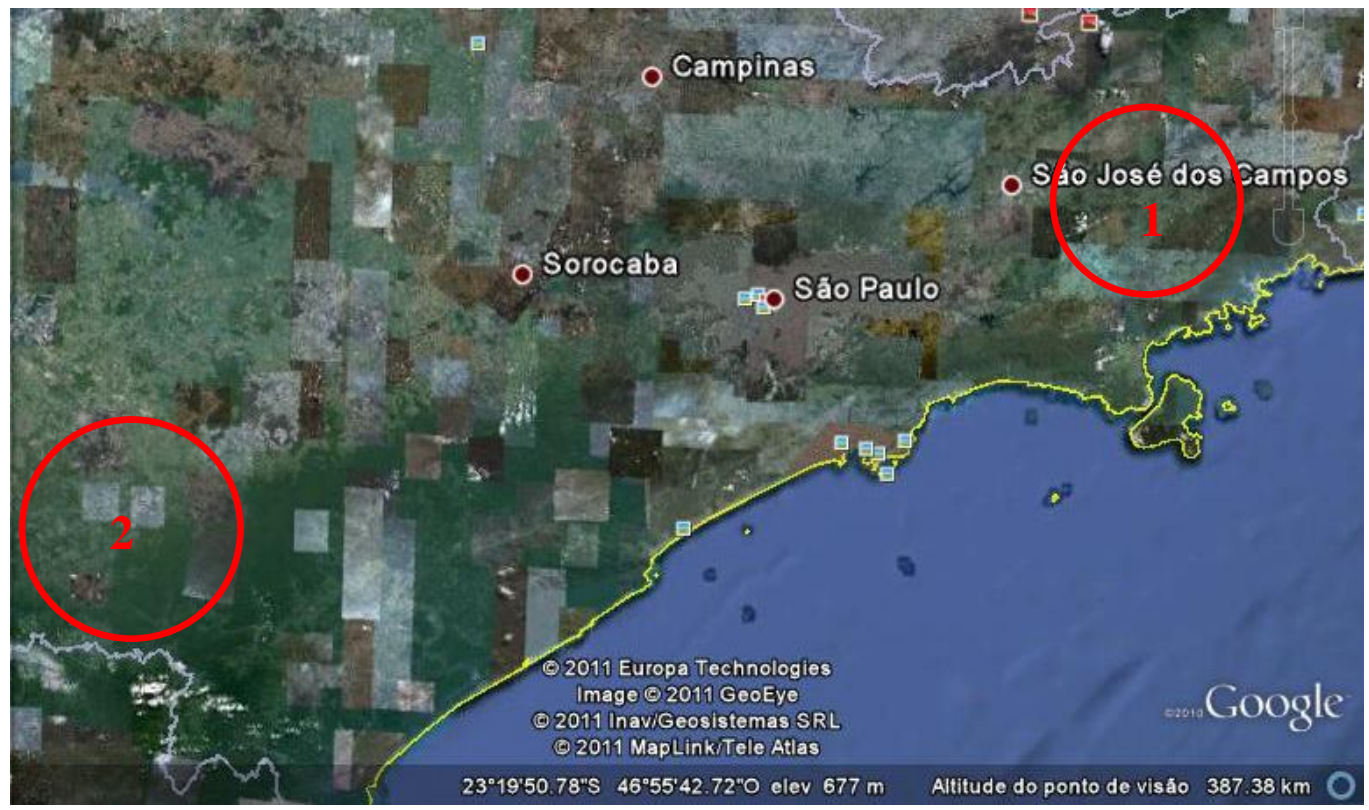

Figura 1. Imagens de satélite das regiões de coleta. Região 1 - Fragmentos de Floresta Atlântica no município São Luís do Paraitinga e Núcleo Santa Virgínia, Parque Estadual da Serra do Mar Região 2 - Fragmentos nos municípios de Ribeirão Grande e Capão Bonito e Fazenda Paraíso, floresta contínua com o Parque Estadual Intervales. 
$\mathrm{Na}$ segunda região estão os fragmentos situados no município de Ribeirão Grande $\left(24^{\circ} 05^{\prime} \mathrm{S}, 48^{\circ} 21^{\prime} \mathrm{W}\right)$ e Capão Bonito $\left(24^{\circ} 00^{\prime} \mathrm{S}, 48^{\circ} 20^{\prime} \mathrm{W}\right)$. Os entornos desses fragmentos são normalmente circundados por matrizes de monoculturas, a principal atividade econômica da região. Como paisagem contínua, o Parque Estadual Intervales $\left(24^{\circ} 12^{\prime} \mathrm{S}\right.$ e $24^{\circ} 32^{\prime}$, e $48^{\circ} 03^{\prime}$ e $48^{\circ} 32^{` W}$ ), situado nos municípios de Guapiara, Ribeirão Grande, Sete Barras, Eldorado e Iporanga, Estado de São Paulo (Campos, 1994). Sendo os espécimes coletados dentro da propriedade particular Fazenda Paraíso Eco Lodge $\left(24^{\circ} 14^{`} \mathrm{~S}, 48^{\circ} 22^{`} \mathrm{~W}\right)$, cuja área de floresta é primária, conservada e contínua com aquela do Parque (Figura 2). 

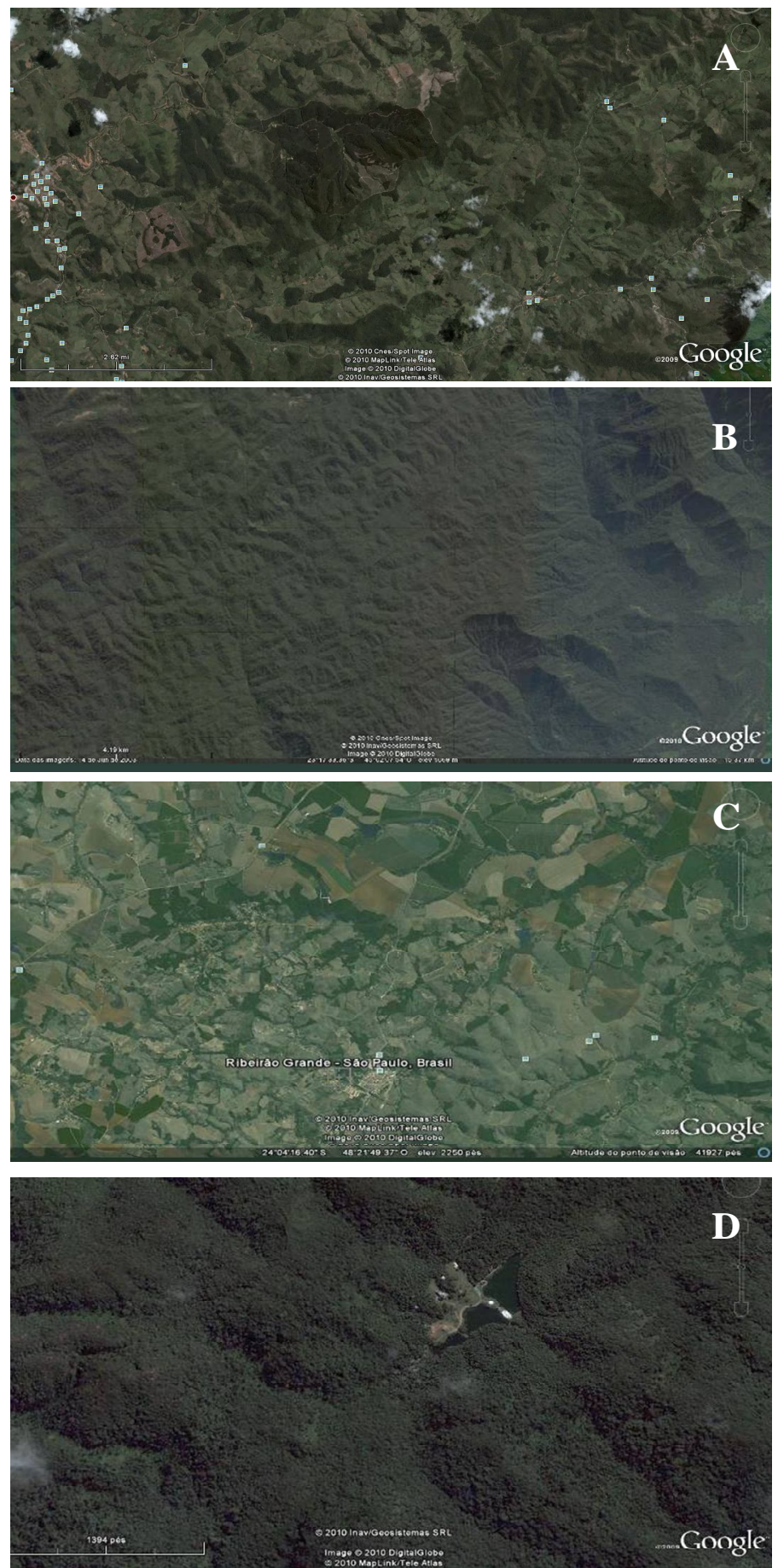

Figura 2. Imagens de satélite das regiões de coleta. A. Área 1 - Fragmentos de Floresta Atlântica no município São Luís do Paraitinga; B. Área 2 - Núcleo Santa Virgínia, Parque Estadual da Serra do Mar; C. Área 3 - Fragmentos no município de Ribeirão Grande; D. Área 4 - Fazenda Paraíso, floresta contínua com o Parque Estadual Intervales. 


\subsection{Temperatura e umidade}

Foram utilizados registradores automáticos de dados Ibbuton (Sistema de Monitoramento de Temperatura Kooltrak) para obtenção de registros de temperatura e umidade. Os aparelhos foram distribuídos a partir da borda, a cada $25 \mathrm{~m}$ até $100 \mathrm{~m}$ no interior da mata, incluindo os corpos de água que se encontravam no interior ou na borda das matas. Para cada transecto um único aparelho para medição de umidade relativa foi colocado. Totalizando 5 aparelhos Ibbutons para cada mata durante um período de pelo menos 10 dias. Foram primeiramente colocados na fazenda Paraíso (mata contínua com o Parque Estadual de Intervales) e três fragmentos adjacentes, no município de Ribeirão Grande, onde o foram coletados os animais. Posteriormente, no Parque Estadual Serra do Mar - Núcleo de Santa Virgínia e um fragmento em São Luís do Paraitinga. As duas etapas foram feitas durante o verão, mas em meses diferentes. Nas áreas abertas onde ocorria a espécie Dendropsophus. Minutus foram colocados aparelhos a 1 e $3 \mathrm{~m}$ dos corpos de água onde foram coletados os animais. Para comparar os parâmetros média, máxima, mínima e amplitude de temperatura e umidade relativa, nos fragmentos e áreas contínuas, foi utilizado o Test $\mathrm{T}$, para amostras independentes.

\subsection{Microbiologia em campo}

Algumas técnicas clássicas em Microbiologia foram adaptadas à realidade do campo, para que houvesse a possibilidade de preservação, ao máximo possível, das características da microbiota cutânea nas amostras obtidas dos animais coleados. 


\subsubsection{Coletas dos animais}

Todos os animais foram coletados por busca ativa, utilizando luvas previamente desinfetadas por álcool a 70\%. Para cada indivíduo, uma luva foi usada e em seguida descartada. Após a captura, os animais foram colocados em sacos tipo ziplock, um indivíduo por saco.

\subsubsection{Coleta de microbiota}

A microbiota cutânea foi coletada logo após a captura dos animais, ainda em campo, nas estalações dos alojamentos onde era preparada a logística para os procedimentos em microbiologia. Os animais foram levados para o alojamento, onde um espaço foi previamente destinado para os trabalhos em microbiologia.

Os animais foram retirados do saco plástico sendo a manipulação realizada com luvas, previamente desinfetadas com etanol 70\%. A seguir, os animais foram lavados com dois banhos de água destilada autoclavada em garrafas previamente esterilizadas em autoclave. Conforme descrito por Lauer et al, 2008 esse procedimento remove a microbiota transiente preservando a microbiota residente. A microbiota da pele foi então amostrada com o auxílio de um cotonete estéril, passando o mesmo em toda a extensão do dorso e ventre, bem como a cabeça e a região gular do animal. Essas áreas de amostragem foram determinadas após verificarmos que foram mais representativas, quando comparadas a esquadros de 1 e $2 \mathrm{~cm}^{2}$, em termos de densidade e de riqueza de colônias, sendo esta última utilizada em estudo posterior (Capítulo2).

O cotonete impregnado com a comunidade microbiana foi depositado em um tubo contendo $1 \mathrm{~mL}$ de solução fisiológica $(\mathrm{NaCl}$ 0,9\%) agitando-se durante 1 min com o auxílio de vórtex. Dessa maneira, espera-se que a maior parte das células presas no cotonete passe 
para a solução, além de garantir a sua homogeneização. A partir dessa primeira amostra que corresponde à comunidade total foram feitas diluições seriadas. Com o auxílio de uma pipeta estéril, $100 \mu \mathrm{L}$ da primeira amostra é transferida para outro tubo contendo $900 \mu \mathrm{L}$ de solução fisiológica estéril, correspondendo à diluição $10^{-1}$ e em seguida o procedimento é repetido para a diluição $10^{-2}$. Essa diluição foi escolhida para o cultivo em placa depois de experimentos pilotos, onde se verificou que essa foi a diluição que permitiu o crescimento de 30 a 300 colônias por placa para a maioria das espécies de anuros testada.

Foram inoculados $100 \mu \mathrm{L}$ da diluição $10^{-2}$ em placas de Petri plásticas estéreis de 90x15mm, contendo meio de cultivo R2A ágar (DIFCO). Escolhemos o R2A ágar porque, em geral, este é o meio de cultivo utilizado nos estudos sobre microbiota cutânea de anfíbios, o que permitiu uma comparação posterior dos nossos resultados com aqueles de outros grupos de pesquisa (Veja capítulo 3, tabela 2). Além disso, disso, outros meio de cultivo foram testados e o R2A ágar apresentou maior efeciência para a obsevação da riqueza de morfotipos (Capítulo 2).

Todo o conteúdo inoculado na placa foi espalhado com alça de Drigalski plástica e estéril, até que o líquido fosse absorvido pelo meio, seguindo o método de "espalhamento em placa", descrito em Madigan et al., 2009. Para cada amostra são feitas duas repetições, obtendo-se assim, triplicatas. Esse procedimento foi realizado em proximidade a uma chama de gás. Foram executados controles com placas de Petri abertas sobre a bancada durante as etapas de coleta e plaqueamento da comunidade microbiana da seguinte forma: duas placas de Petri, contendo o mesmo meio de cultivo, foram deixadas abertas a 10 e $40 \mathrm{~cm}$ da chama. Para essas últimas, ao final do tempo de crescimento das outras placas, não foi esperado crescimento bacteriano. 
As placas foram incubadas por $48 \mathrm{hs}$ a temperatura ambiente, conforme é realizado para cultivo de bactérias de amostras de solo. A incubação foi feita em campo, para que as temperaturas fossem aquelas da localidade onde foram coletadas as amostras. Alguns já foram detectados nas primeiras $24 \mathrm{hs}$ e outros foram visualizados após o terceiro dia. Assim, o número de colônias foi determinado após 48 hs e 72 horas de crescimento. Após a coleta da microbiota os animais foram soltos. Apenas dois animais de cada espécie e de cada área de coelta foram preservados em álcool a $70 \%$ para verificação da taxonomia e criação de uma pequena coleção de referência.

Por fim, cabe ressaltar que, pelos métodos utilizados, todos os resultados obtidos neste trabalho (todos os capítulos) são relacionados à porção cultivável, em meio R2A ágar, da microbiota cutânea das espécies anuros estudadas.

\subsubsection{Estimativa da densidade bacteriana.}

Para a contagem das colônias, foi utilizado o método padrão "contagem de placa heterotrófica" (CPH), utilizado comumente para estimar o número de bactérias heterotróficas vivas, coletadas em corpos de água. Uma colônia que surge a partir da proliferação de uma única célula bacteriana é denominada "unidade formadora de colônia" ou UFC (Madigan et al., 2004) e essa nomenclatura é utilizada no decorrer deste trabalho.

A contagem foi feita considerando todas as unidades visualizadas com o auxílio de lupa sobre um contador de colônias da marca (Quimis®). Para se estimar a quantidade de UFC por amostra a seguinte fórmula foi utilizada:

Fator de diluição x UFC 
Sendo o "fator de diluição" igual a 100, UFC, a quantidade de unidades formadoras de colônias contadas na placa e o denominador corrige o volume para $\mathrm{mL}$ (Eaton et al., 1995). As médias de cada triplicata de placas foram consideradas. Para se estudar a dependência da densidade bacteriana residente sobre a pele dos anuros Dendropsophus minutus, Proceratophrys boiei, Aplastodiscus leucopygius e Phyllomedusa distincta, foram utilizados testes de Kruskal-Wallis, dependentes da espécie, paisagem, localidade e microhabitat, seguidos de testes de Mann-Whitney para comparações pareadas.

\section{Resultados}

\subsection{Coleta dos espécimes}

Um total de 187 indivíduos adultos foi coletado. Destes, 52 foram da espécie Proceratophrys boiei, família Cicloramphidae; 73 indivíduos de Dendropsophus minutus, família Hylidae; 28 indivíduos de Aplastodiscus leucopygius, família Hylidae; e 34 indivíduos de Phyllomedusa distincta, família Hylidae.

Em relação às localidades, para $P$. boiei foram 5 indivíduos coletados no Parque Estadual Serra do Mar - Núcleo de Santa Virgínia;18 no município de São Luís do Paraitinga, 17 na fazenda Paraíso - Parque Estadual de Intervales - e 12 no município de Ribeirão Grande. Houve 31 indivíduos de D. minutus capturados Parque Estadual Serra do Mar - Núcleo de Santa Virgínia; 9 no município de São Luís do Paraitinga, 17 na fazenda Paraíso - Parque Estadual de Intervales - e 16 no município de Ribeirão Grande. Foram coletados 16 indivíduos de $P$. distincta espécimes na fazenda Paraíso - Parque Estadual de Intervales - e 18 no município de Ribeirão Grande. Finalmente, foram capturados 14 indivíduos de A. leucopygius no Parque Estadual Serra do Mar - Núcleo de Santa Virgínia; 14 no município de São Luís do Paraitinga (Tabela 1). 
Tabela 1. Total de indivíduos coletados por espécie e localidade.

\begin{tabular}{llllll}
\hline Espécie & Microhabitat & NSV & SLP & INT & RG \\
\hline Dendropsophus minutus & Área aberta & 31 & 9 & 17 & 16 \\
Proceratophrys boiei & Folhiço & 5 & 18 & 17 & 12 \\
Aplastodiscus leucopygius & Árvores & 14 & 14 & - & - \\
Phyllomedusa distincta & Árvores & - & - & 16 & 18 \\
\hline
\end{tabular}

Abreviações: NSV, Núcleo de Santa Virgínia; SLP, São Luís do Paraitinga; INT, Intervales - Fazenda Paraíso; RG, Ribeirão Grande

\subsection{Densidade de colônias bacterianas}

Previamente às análises de densidade total, foi detectado que as espécies de anuros estudadas possuem tamanhos diferenciados. Por exemplo, a média de comprimento rostrocloacal em A. leucopygius é $39,8 \mathrm{~mm}, P$. boiei $52,75 \mathrm{~mm}, P$. distincta é $56,14 \mathrm{~mm}$ e $D$. minutus é 39,87 mm (Figura 2). Julgamos que essas diferenças nas dimensões corpóreas das espécies poderiam atuar como um viés nos resultados finais de densidade microbiana. Por isso, foram feitas medições de massa e comprimento rostro-cloacal e uma função dessas duas medidas serviu para obter uma variável proporcional às áreas corpóreas amostradas dos indivíduos. Para avaliar a importância do tamanho dos espécimes, e, por consequiência, a área corpórea amostrada, nas médias de densidade de microbiota cutânea desses indivíduos, foi utilizada estatística $F$ e teste de correlação com esses fatores morfométricos, onde se verificou que o tamanho corpóreo dos animais não é um bom preditor das médias de densidade microbiana $\left(\mathrm{r}^{2} 0,26 ; F\right.$ crítico 2,$\left.26 ; F 1,3\right)$. Neste trabalho, o termo densidade refere-se ao número total de unidades formadoras de colônias para cada espécime de anfíbio amostrado. 


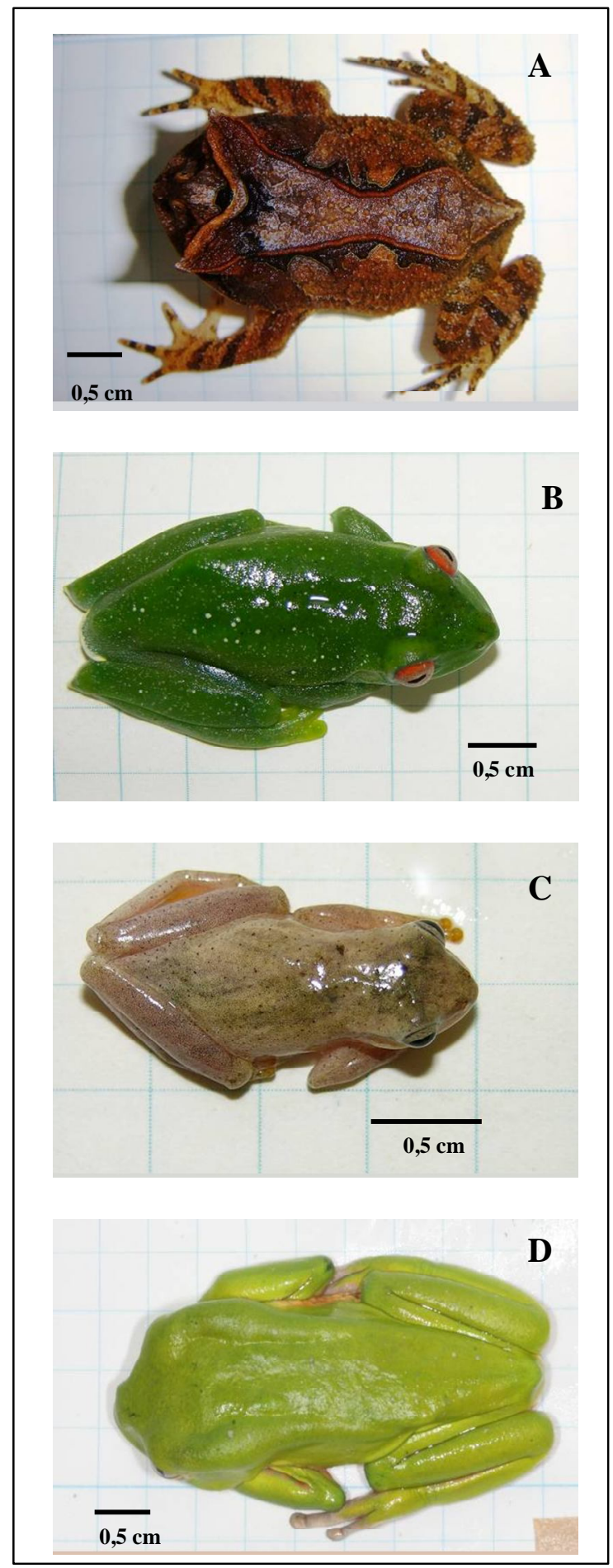

Figura 2. Espécies de anuros estudadas, com escala de tamanho corpóreo. A. Proceratophrys boiei; B. Aplastodiscus leucopygius; C. Dendropsophus minutus; D. Phyllomedusa distincta. 
A densidade bacteriana na pele dos indivíduos testados variou de 0 a 1.278.000 UFC/mL, sendo observada diferenças entre as espécies de anuros analisadas $\left(p=9,49^{-21}\right)$ (Figura 3).

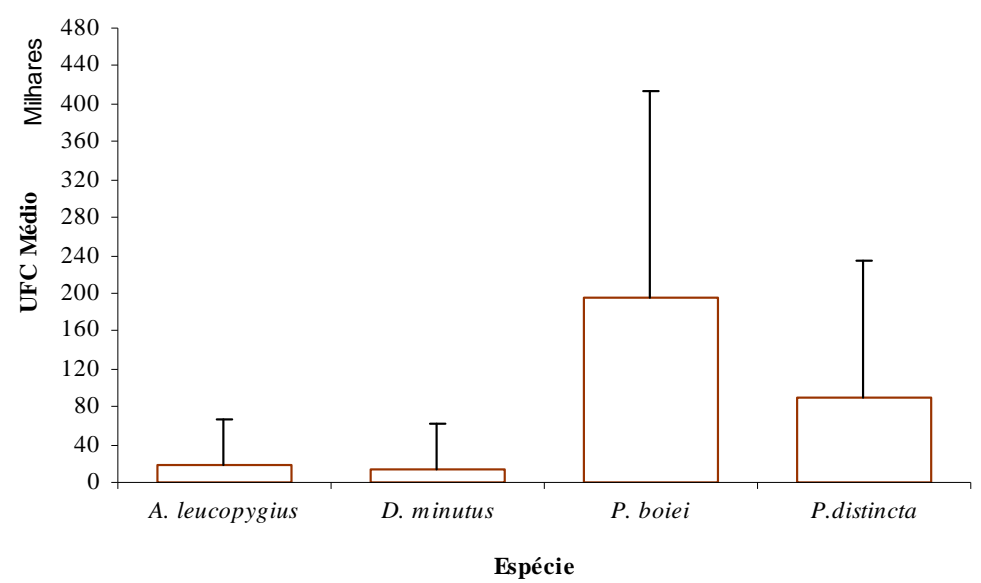

Figura 3. Média e desvio padrão das densidades de UFC/ml amostradas em quatro espécies de anuros.

Com o auxílio do teste de Mann-Whitney, foram feitas análises pareadas de espécies para verificar diferenças na densidade de UFC/mL sobre a pele dos indivíduos, entre espécies, com nível de significância $p=<0,05$. Vimos que, com exceção do par $D$. minutus e A. leucopygius, os demais pares de espécies são diferentes entre si (Tabela 2).

Tabela 2. Comparação de médias de UFC/mL entre pares de espécies, utilizando teste de Mann-Whitney.

\begin{tabular}{ccccc}
\hline P-valor (5\%) & A. leucopygius & D. minutus & P. boiei & P. distincta \\
\hline A. leucopygius & - & 0,172 & $4,85^{-10}$ & $9,74^{-5}$ \\
D. minutus & - & $1,37^{-17}$ & $2,36^{-8}$ \\
P. boiei & & & - & $1,95^{-5}$ \\
P. distincta & & & & - \\
\hline
\end{tabular}


A análise de densidade de UFC/mL em duas paisagens: fragmento e área contínua de Floresta Atlântica mostrou que, ao considerarmos a microbiota cutânea amostradas em todas as espécies de anuros estudadas, há diferenças entre os dois grupos $\left(p=8,64^{-3}\right)$ (Figura 4).

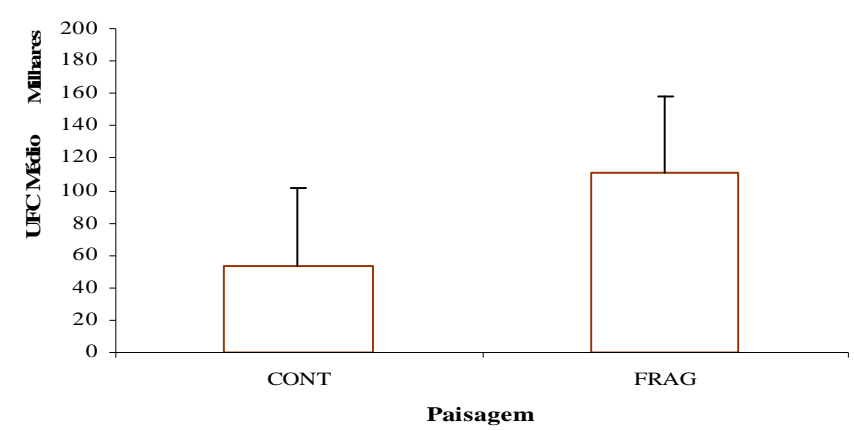

Figura 4. Média e desvio padrão das densidades de UFC/ml amostradas em quatro espécies de anuros nas paisagens contínuas e fragmentos.

Ao ser feita uma análise por espécie nas duas paisagens: fragmento e área contínua foi verificado que apenas $P$. boiei $\left(p=1,39^{-2}\right.$ ) apresenta diferença na densidade de UFC. Nesta espécie, os indivíduos coletados nos fragmentos apresentam uma densidade superior de UFC/mL quando comparados àqueles presentes nas áreas contínuas. As demais espécies: A. leucopygius $\left(p=1,89^{-1}\right)$, D. minutus $(p=9,95-1) ;$. distincta $\left(p=8,14^{-2}\right)$ não mostraram diferenças entre os dois grupos(Figura 5). 


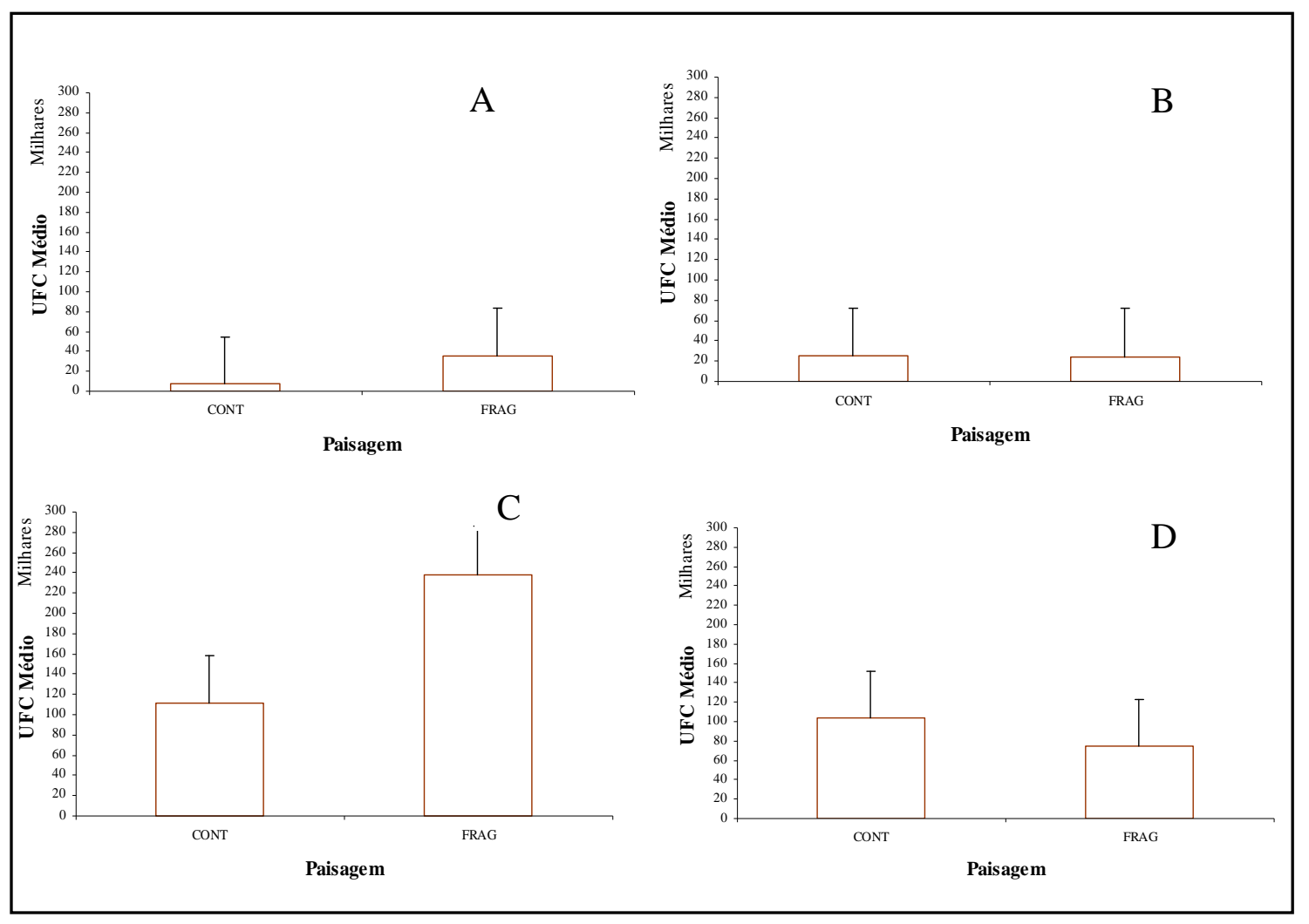

Figura 5. Médias e desvio padrão de densidade de UFC/ $\mathrm{mL}$ de quatro espécies de anuros: A. A. leucopygius; B. D. minutus; C. P. boiei; D. P. distincta, em duas paisagens: Contínua (CONT) e Fragmento (FRAG).

A análise considerando as quatro áreas de coleta individuais, ou seja, não mais agrupadas em paisagens (fragmento e área contínua), mostrou que há diferenças entre elas $\left(p=2,36^{-6}\right)$. Sendo a maior média encontrada em São Luís do Paraitinga $(D P=252.842)$, seguido do Parque Estadual de Intervales $(D P=120.721)$, Ribeirão Grande $(D P=130.14)$ e Parque Estadual Serra do Mar - Núcleo de Santa Virgínia $(D P=43.754)$ (Figura 6). 


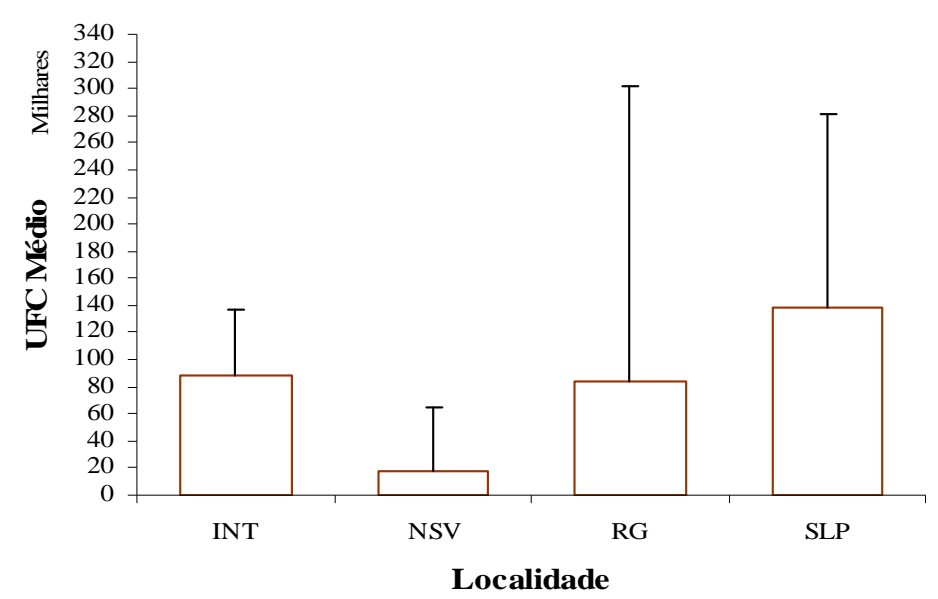

Figura 6. Média e desvio padrão da densidade de UFC/ml nas localidades: Intervales (INT); Núcleo de Santa Virgínia (NSV); Ribeirão grande (RG) e São Luís do Paraitinga (SLP).

Foram feitas análises entre pares de localidade para cada espécie, onde foi observado que o maior número de pares com diferença significativa entre si corresponde àqueles que consistem de uma área contínua e outra fragmentada: em Proceratophrys boiei: Intervales - Ribeirão Grande (INT - RG) e Intervales - São Luís do Paraitinga (INT - SLP); Dendropsophus minutus: Núcleo de Santa Virgínia - Ribeirão Grande (NSV - RG) e Intervales - São Luís do Paraitinga (INT - SLP) e em Phyllomedusa distincta: Intervales Ribeirão Grande (INT - RG). Esses resultados devem determinar a diferença entre área contínua e fragmento observada nas análises anteriores, onde a densidade das comunidades amostradas de anfíbios em fragmentos foi significativamente maior que daquelas amostras de anfíbios em áreas contínuas (Tabela 3). 
Tabela 3: Comparação de médias de UFC/mL entre pares de localidades para cada espécie, cujo resultado é mostrado pelo teste Kruskal-Wallis (K-W).

\begin{tabular}{|c|c|c|c|c|}
\hline & Áreas & Médias & Desvio & K-W \\
\hline \multirow[t]{6}{*}{ P. boiei } & NSV - INT & $114266-17704$ & $137456-90359$ & $6,67-1$ \\
\hline & NSV - RG & 114266 - 201805 & $90359-61335$ & $9,17-2$ \\
\hline & NSV - SLP & $114266-287824$ & $90359-322813$ & $1,8-1$ \\
\hline & INT - RG & $117704-201805$ & $137456-61335$ & $2,39-2$ \\
\hline & INT - SLP & $117704-287824$ & $137456-322813$ & $1,46-2$ \\
\hline & RG - SLP & 201805 - 287824 & $61335-322813$ & $7,99-1$ \\
\hline \multirow[t]{6}{*}{ D. minutus } & NSV - INT & $389-3908$ & $9243,8-91979$ & $3,19-3$ \\
\hline & NSV - RG & $389-9437$ & $9243,8-14394$ & $2,97-3$ \\
\hline & NSV - SLP & $3889-13381$ & $9243,8-32833$ & $2,94-1$ \\
\hline & INT - RG & $39080-9437$ & $91979-14394$ & $3,87-1$ \\
\hline & INT - SLP & $39080-13381$ & $91979-32833$ & $2,42-2$ \\
\hline & RG - SLP & $9437-13381$ & $14394-32833$ & $1,09-1$ \\
\hline P. distincta & INT - RG & $117571-73903$ & $123527-160404$ & $2,75-2$ \\
\hline A. leucopygius & NSV - SLP & $12166-26333$ & $20806-6463$ & $8,54-1$ \\
\hline
\end{tabular}

Abreviações: NSV, Núcleo de Santa Virgínia (área contínua); SLP, São Luís do Paraitinga (fragmento); INT, Intervales (área contínua); RG, Ribeirão Grande (fragmento); K-W, Kruskal-Wallis.

A análise de comparação dos microhabitats mostrou que existem diferenças entre os eles (Figura 7).

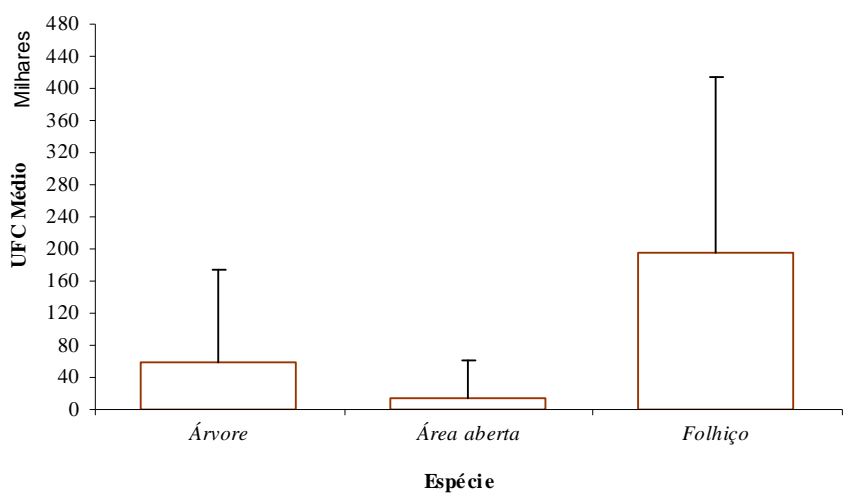

Figura 7. Média e desvio padrão da densidade de UFC/ml da microbiota cutânea de anfíbios, representantes de três microhabitats distintos. 
As análises dos pares de microhabitats mostraram que há diferenças significativas entre os pares dos três microhabitats estudados (Tabela 4).

Tabela 4. Comparação de médias de UFC/mL entre pares de microhabitats, utilizando teste de MannWhitney

\begin{tabular}{llll}
\hline P-valor (5\%) & Árvore & Área aberta & Folhiço \\
\hline Árvore & - & 0,00 & $4,85^{-10}$ \\
Área aberta & & - & $1,06^{-15}$ \\
Folhiço & & & - \\
\hline
\end{tabular}

\subsection{Análises de temperatura e umidade}

Durante a obtenção dos dados de temperatura, perdemos algumas informações devido ao mau funcionamento dos equipamentos. Tal fato nos privou da inclusão dos dados de áreas abertas e alguns pontos do interior das matas, no entanto, julgamos que os registros obtidos foram suficientes para constatar os padrões de temperatura e umidade dos fragmentos e áreas contínuas.

Para temperatura, houve diferença significativa entre as médias de temperaturas, sendo a paisagem fragmentada mais quente que a paisagem contínua. Não foram observadas diferenças significativas para os demais parâmetros de temperatura (Figura 8).

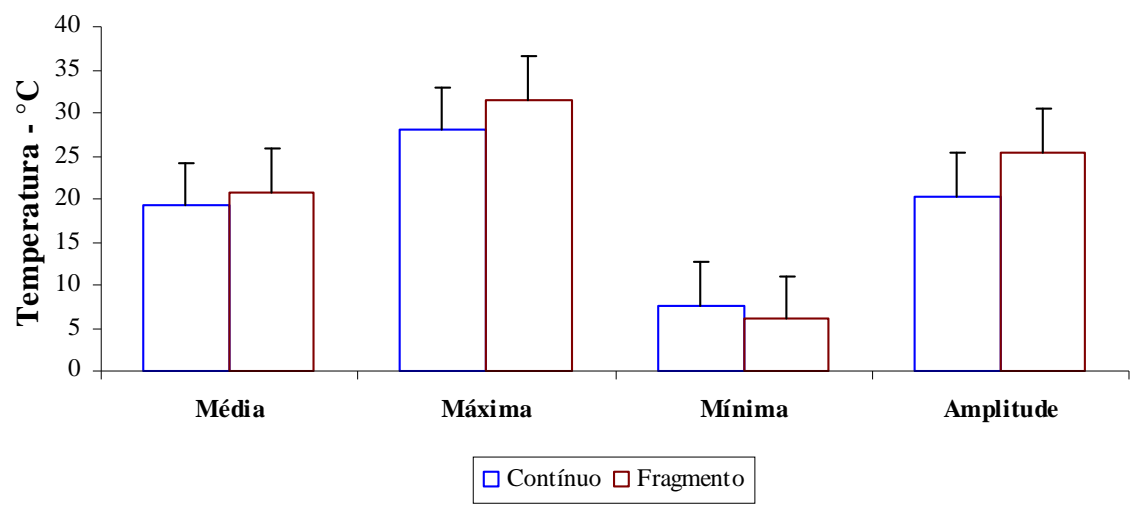

Figura 8. Médias dos parâmetros média, máxima, mínima e amplitude de temperatura em áreas contínuas e fragmentos. 
Os parâmetros de umidade relativa não apresentaram diferenças significativas entre as paisagens (Figura 9).

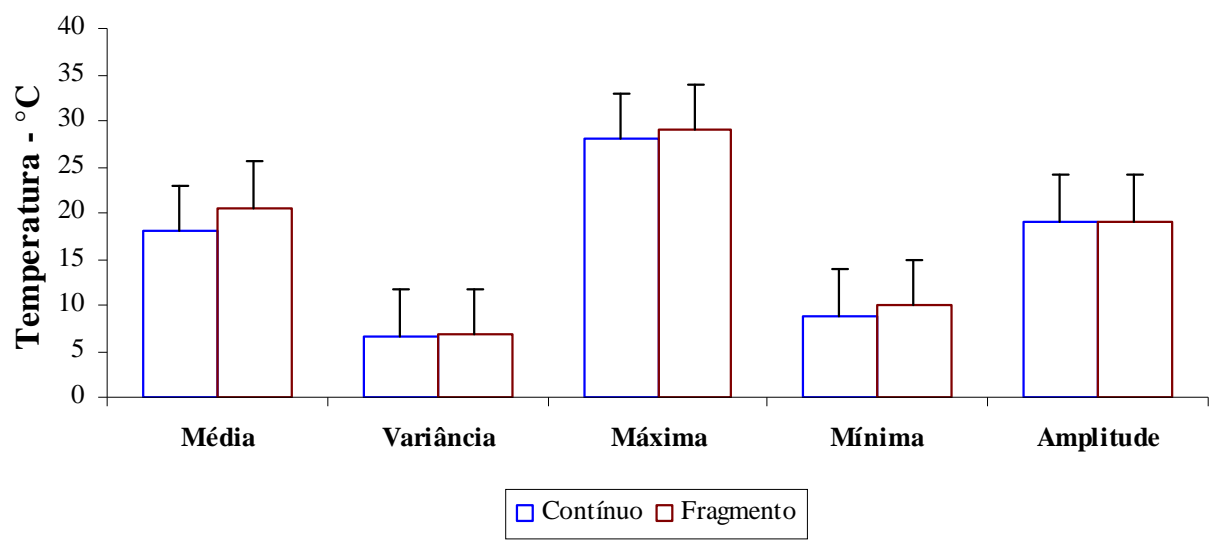

Figura 9. Médias e desvios padrão dos parâmetros média, máxima, mínima e amplitude de umidade relativa em áreas contínuas e fragmentos.

\section{Discussão}

Apesar da impossibilidade de fazer comparações com estudos anteriores, dado ao caráter pioneiro da problemática proposta nesta pesquisa, as análises de densidade microbiana permitiram identificar alguns padrões de comunidades cutâneas das espécies de anuros estudadas.

Diferença de densidade microbiana entre espécies de anuros - O primeiro padrão que pode ser identificado são as diferenças entre as espécies havendo em $P$. boiei uma densidade muito superior de bactérias, seguido das densidades de $P$. distincta, A. leucopygius e, por último, D. minutus. Essa diferença entre espécies pode ser explicada por dois fatores principais: a morfo-fisiologia da pele e a história natural das espécies.

Em relação do primeiro fator, sabemos que há diferenças interespecíficas relacionadas às secreções cutâneas das glândulas dérminas dos anfíbios, referentes às 
moléculas componentes (Conlon et al., 2004, Conlon et al., 2007). Algumas dessas moléculas são bioativas produzindo efeito antimicrobiano contra espécies de bactérias e fungos (Rollins-Smith et al., 2002). Além disso, P. distincta, A. leucopygius e D.minutus, possuem a superfície da pele constantemente umidificada por secreções mucosas, e cera no caso de $P$. distincta, que podem limitar a densidade microbiana. Concomitantemente, a morfologia da pele também pode explicar a maior densidade observada em $P$. boiei, uma vez que esta é a espécie com maior rugosidade de pele das espécies de anuros estudadas, o que pode facilitar a instalação e permanência de uma densidade superior de bactérias. Por outro lado, a menor densidade microbiana em $D$. minutus pode ser explicada pela lisa textura dessa superfície da pele dessa espécie.

O segundo fator, história natural das espécies, também pode ser um modulador da diversidade e densidade bacteriana residente na pele dos anfíbios. Por exemplo, os indivíduos da espécie $P$. boiei são bastante ativos, se deslocando por longas distâncias, o que pode ser percebido através dos encontros com indivíduos em trilhas distantes dos corpos de água, onde eles são achados durante o período reprodutivo (Zina et al., 2007). Esses hábitos devem permitir que o animal entre em contato com um amplo mosaico de comunidades microbioanas que ocorrem dentro da mata, quando comparado com as demais espécies de anuros. $P$. distincta é uma espécie de hábito arborícola, passando a maior parte da vida sobre árvores (Bertoluci, 2005). A.leucopygius é encontrada à noite principalmente sobre árvores e também vocalizando sobre vegetações associadas a corpos de água, como taboais e charcos temporários (Heyer, et al., 1990). D. minutos, espécie que tanto vocaliza nas margens quanto nada ativamente em corpos de água lênticos (Pombal \& Haddad, 2005), nesse estudo foi principalmente encontrada em áreas abertas e apresentou os menores valores de densidade microbiana cutânea, nos chamando à atenção o fato de que para algumas amostras, nenhuma 
colônia foi detectada na placa, o que não aconteceu para as demais espécies. As freqüentes lavagens durante as incursões e nado ativo nos corpos de água podem contribuir para uma menor densidade bacteriana amostrada nessa espécie.

É razoável ainda propor que algumas espécies de anfíbios lancem mão de uma microbiota cutânea com alta densidade e outras tenham como principal barreira de proteção uma maior complexidade e efeito em termos de moléculas bioativas secretadas na pele e, que, portanto, determinam uma densidade inferior de bactérias residentes.

\section{Diferença de densidade microbiana na pele de anuros em duas paisagens -}

Apesar de haver uma tendência que indica uma maior densidade de microbiota cutânea em anuros de paisagens fragmentadas (tabela 3), o resultado mais expressivo dessa realidade é referente à espécie $P$. boiei. Esse resultado pode estar associado ao fato de que o substrato solo, principal superfície de contato dessa espécie, experimenta grandes flutuações nas características de microbiotas, principalmente em remanescentes de floresta. Sendo afetado tanto pela lixiviação de compostos e microrganismos da matriz, quanto pelas próprias variáveis abióticas e bióticas alteradas no interior da mata (Saunders et al., 1991). As demais espécies não indicaram a existência de um forte efeito da paisagem sobre a densidade microbiana total, mostrando que existem diferenças interespecíficas.

Embora possamos fazer menções quanto aos componentes que modulam os perfis das comunidades microbianas da pele dos anfíbios, as conseqüências de tais perfis estabelecidos, ou de alterações desses por causas antropogênicas, são de difícil previsão devido ao fato de ainda não entendermos qual o significado das densidades total ou relativa de microbiota cutânea para as espécies estudadas. É possível que existam processos densidade dependentes, como foi identificado para a bactéria Chromobacterium violaceum, isolada da espécie de salamandra Plethodon cinereus, onde a produção de antibiótico pela 
bactéria residente é dependente da densidade de Batrachochytrium dendrobatidis, que causa infecções cutâneas (Brucker et al., 2008). Estudos que investiguem a densidade, biomassa e atividade, principais parâmetros ecológicos da estrutura e função dos ecossistemas microbianos (Atlas \& Bartha, 1993), irão elucidar o significado da densidade dessas comunidades para os anfíbios e os ambientes. Assim como o significado dos ambientes e dos anfíbios para as microbiotas cutâneas.

Uma relação direta do microhabitat com os perfis de densidade microbiana encontrados poderia ser verificada por meio de estudos da densidade microbiana dos microhabitats ocupados. Isso porque o solo, a vegetação e a água variam em estrutura física, composição de nutrientes, temperatura e potencial de água, o que influencia os tipos de microrganismos presentes (Madigan et al., 2004). Esses estudos adicionais relacionados aos microhabitats devem considerar a co-variável filogenia, que deve ter influenciado fortemente os resultados observados na análise de microhabitat.

Além das características sugeridas como determinantes dos padrões observados, tais como características inerentes à pele e tipo de hábitat ocupado, poderia existir um viés metodológico em nossos resultados: o meio de cultivo utilizado. Este apesar de ser utilizado nos estudos de diversidade microbiana e em todos aqueles de microbiota cutânea de anfíbios, poderia como qualquer meio de cultivo, selecionar algumas entidades microbianas e não outras (Atlas \& Bartha, 1993). Estudos futuros de contagem de células por microscopia de fluorescência trarão resultados mais acurados da densidade microbiana residente da pele dos anfíbios.

Apesar de não terem sido detectadas diferenças entre as paisagens contínuas e fragmentadas, para a maioria dos parâmetros de temperatura estudados, a diferença significativa entre as médias de temperatura podem ter influência nos padrões de densidade 
observados, dada a influência da temperatura no crescimento e fisiologia bacterianos. Assim, médias superiores de temperatura nos fragmentos estudados podem ter um efeito nas densidades da microbiota cutânea observada. Amostragens que incluam outras estações do ano, além do verão, poderão elucidar melhor os padrões de umidade relativa e tempetatura existentes nessas áreas. Além disso, outras variáveis que podem ser importantes ou melhores preditores dos perfis dessas comunidades microbianas, tais como $\mathrm{pH}$, disponibilidade hídrica nos substratos e incidência de radiação, ou ainda, a interação entre diversas variáveis ambientais.

\section{Conclusão}

A comunidade microbiana residente da pele de anfíbios configura-se como uma interessante interface entre o animal e o ambiente, onde inúmeros processos biológicos podem ser abordados. O presente estudo trouxe uma perspectiva inovadora onde foi ressaltada a existência de padrões de densidades microbianas sobre a pele desses animais. Tais padrões apontam para a influência dos fatores: espécie, história natual e paisagem, na determinação da densidade bacteriana cutânea. O microhabitat pode também ser um componente determinante dos padrões observados, sendo o solo o microhabitat que proporciona uma maior densidade microbiana.

A diferença entre as médias de temperatura nas paisagens estudadas é o nosso primeiro indicativo de que há diferença relacionada aos fatores abióticos nessas paisagens e, sendo a temperatura um fator muito importante para o crescimento de microrganismos, é muito provável que esta tenha efeito sobre a densidade bacteriana cutânea. Além da temperatura e umidade relativa, outras variáveis ambientais devem estar incluídas em futuras análises dos padrões de microbiota cutânea de anfíbios para avaliar mais profundamente a 
importância das variáveis abióticas e contexto ambiental para a determinação dos perfis dessas comunidades. Análises de densidade microbianas deverão incluir estimativas feitas através de contagem de célula por microscopia de fluorescência, para que o viés do meio de cultivo seja eliminado. Estudos adicionais incluindo os componentes biomassa e atividade, juntamente com a densidade microbiana poderão elucidar o significado das diferenças encontradas entre espécies e entre paisagens, principalmente, através do entendimento da estrutura e função dessas comunidades.

O estudo trouxe um marco que aponta para a necessidade de novas pesquisas, pois fica demonstrado que, em alguns casos, a paisagem pode influenciar notoriamente a comunidade microbiana residente na pele dos anfíbios. É esperado que existam conseqüências ecologicamente relevantes nessas diferenças e estudos adicionais poderão contribuir para a elucidação de processos ecológicos, fisiológicos e evolutivos, nessa interface. 


\section{Capítulo 2}

Caracterização da microbiota cutânea de quatro espécies de anuros em diferentes fragmentos de Floresta Atlântica: Riqueza e potencial antimicrobiano. 


\section{Resumo}

Diversas pesquisas têm demonstrado o potencial de bactérias, componentes das comunidades microbianas da pele dos anfíbios, contra importantes patógenos, como o fungo Batrachochytrium dendrobatidis. O que serve como um indicativo de que a microbiota atua como um componente de proteção desses animais. Apesar de ainda conhecermos pouco, esse aspecto da história natural dos anfíbios é muito relevante no contexto atual de impactos ambientais e doenças infecciosas no meio ambiente. A riqueza de morfotipos de colônias bacterianas é uma medida rápida e pode ser considerada como um indicativo da diversidade microbiana cultivável das comunidades. Esse estudo teve como objetivo geral uma análise sobre o potencial antimicrobiano de colônias bacterianas isoladas das comunidades cutâneas de anfíbios de quatro espécies de anfíbios: Proceratophrys boiei, Dendropsophus minutus, Aplastodiscus leucopygius e Phyllomedusa distincta, bem como uma análise comparativa da riqueza de comunidades microbianas presentes em anuros coletados em fragmento e área contínua de Floresta Atlântica. Todas as espécies apresentaram morfotipos de colônias bacterianas com potencial antimicrobiano, nos testes cross-streak. P. boiei apresentou a maior riqueza e número de morfotipos com atividade antimicrobiana. As diferenças podem ser determinadas por dois componentes principais: modo de vida e características da pele. $\mathrm{O}$ entendimento dos fatores ambientais que modulam as diferenças acerca da riqueza e diversidade de bactérias com potencial antimicrobiano pode auxiliar na determinação de estratégias conservacionistas, através da predição de quais ou o que torna as espécies de anfíbios mais vulneráveis, com base nos perfis das comunidades microbianas da pele. 


\section{Introdução}

O termo microbiota residente no contexto desse trabalho é definido como a comunidade de microrganismos viventes na epiderme dos anfíbios. Essa comunidade pode atuar como primeira barreira protetora, impedindo a infecção por outros microrganismos que possam invadir o corpo desses animais através da pele (Austin, 2000; Harris et al. 2006; Woodhams, 2007; Lauer et al. 2007; Ashcroft, 2008; Brucker et al., 2008; Lauer et al., 2008; Lam, et al. 2009; Harris et al., 2009). Apesar de ainda conhecermos pouco, esse aspecto da história natural dos anfíbios é muito relevante no contexto atual de impactos ambientais e doenças infecciosas no meio ambiente. Isso porque diversas entidades microbianas, que são apontadas na literatura como causadoras de epidemias em populações de anfíbios, aparentemente atacam a partir de contato com a epiderme. Dessa forma, a comunidade microbiana residente na pele desses animais poderia ter um significado funcional no contexto de uma primeira barreira protetora.

Em 2006, Harris e colaboradores isolaram e identificaram alguns gêneros de espécies de bactérias presentes na pele de duas espécies de salamandras (Amphibia, Caudata) e com aparente ação inibidora do crescimento de fungos, inclusive $B d$. Lauer et al., 2007 em estudo de caracterização da microbiota residente de salamandras da espécie Plethodon cinereus, revela uma ampla distribuição de bactérias sobre a pele, como também bactérias com propriedades antifúngicas. Também em 2007, Woodhams e colaboradores estudaram duas populações de Rana mucosa expostas ao fungo, estando uma delas em declínio e a outra persistindo apesar da ocorrência do patógeno. Nesse estudo foi constatado que a variação na suscetibilidade ao $B d$ não estava associada às alterações na composição dos peptídeos da secreção mucosa, mas acontecia em associação a diferenças na microbiota cutânea residente. A proporção e a frequiência de rãs hospedando pelo menos uma espécie de bactéria com ação 
inibitória de crescimento de $B d$ foi significativamente maior naquela população resistente ao fungo.

Lauer et al., 2008 isolaram bactérias da pele de três populações de salamandras e realizaram ensaios destas contra dois diferentes tipos de fungo: Mariannea elegans e Rhizomucor variabilis, que atacam os ovos destes anfíbios. Através de identificação molecular, chega ao número de 48 espécies de bactérias cutâneas, além de constatar que a maior parte dos indivíduos de todas as populações hospedava bactérias contra pelo menos dos dois fungos. Brucker et al., 2008 detectou dois metabólitos com potente ação contra fungos patógenos, na pele de salamandras da espécie Plethodon cinereus. Estes metabólitos são produzidos pela bactéria simbionte Janthinobacterium lividum em concentrações letais para o fungo $B d$. No conjunto, esses trabalhos fornecem evidência inicial à hipótese de que bactérias cutâneo-residentes antifúngicas têm um importante papel no sistema de defesa dos anfíbios.

O potencial de alguns elementos dessa comunidade contra patógenos in vitro é conhecido, porém esta propriedade consta em estudos recentes e carece de investigações mais profundas, ressaltando o significado desses elementos para os animais num contexto ecológico. Poucos demonstram a ação de elementos isolados da microbiota cutânea contra importantes patógenos que atuam por meio da pele dos anfíbios, tais como Aeromonas hydrophila, que atua na epiderme e trato digestivo, é oportunista tornando-se patogênica quando o indivíduo está sob stress; Iridovidae, o iridovírus, coloniza a pele e o fígado; e Batrachochytrium dendrobatidis é o fungo quitrídeo considerado principal ameaça às populações de anfíbios em termos doenças. As colônias desse fungo atacam o epitélio queratinizado e partes da boca de girinos. (Carey, et al., 1999; Weldon et al.; 2004; RollinsSmith et al., 2002). Mariannaea sp., o qual é um fungo ascomiceto que ataca ovos de 
salamandras e o próprio fungo $B$. dendrobatidis. No momento, existe grande expectativa que os resultados positivos de ensaios de inibição de crescimento bacteriano, onde se verifica a produção de antibióticos com efeito contra esses patógenos, realizados in vitro possam acontecer in vivo.

Sabemos que algumas populações declinam de forma rápida quando são expostas a fungos como $B d$, enquanto outras persistem, parecendo oferecer algum tipo de resistência contra o agente infeccioso. Essa resistência pode estar relacionada a variações na patogenicidade do agente, a densidade e diversidade de microorganismos na epiderme, bem como a densidade de patógeno a que o hospedeiro é exposto, na eficácia das secreções de peptídeos antimicrobianos ou nas características das populações (como história de vida, fisiologia, comportamento e ecologia) e ainda variações na comunidade microbiana da epiderme (Harris et al., 2006). A diversidade microbiana sobe a pele dos anuros pode ser um aspecto determinante durante as interações da comunidade de microrganismos residentes com uma espécie patógena com o potencial para invadir o corpo desse hospedeiro.

A riqueza das comunidades microbianas residentes na pele dos anfíbios deve ser modulada por fatores ambientais e fatores inerentes à biologia dos animais. A secreção de alguns compostos, por meio de glândulas dérmicas, devem ser importantes componentes na determinação dos perfis dessas comunidades microbianas. O muco é composto de secreção ácida e rica em carboidratos, que podem atrair fungos e bactérias e servir de fonte nutritiva para esses microorganismos (Ducklow \& Michell, 1979; Duellman \& Trueb, 1994; Brizzi et al., 2002). Moléculas bioativas, como peptídeos antimicrobianos, secretados por glândulas granulares, componentes do sistema inato, podem prevenir a invasão de microrganismos patógenos através da pele ou mesmo limitar o crescimento destes sobre a mesma, diminuindo o risco de infecções, ou mesmo atuar como um agente seletivo, permitindo que apenas 
algumas populações se estabeleçam sobre a pele (Rollins-Smith et al., 2002; Ashcroft et al., 2007; Simmaco et al., 1997; Conlon et al., 2007; Bevier et al., 2004; Toledo \& Jared, 1995). Determinadas temperaturas corpóreas podem favorecer o crescimento de certos grupos de microrganismos e prejudicar outros. Este último caso foi observado na espécie Litoria chloris, que apresenta eventos de febre comportamental - aumento da temperatura corpórea por termorregulação - o que diminui a infestação por Bd (Woodhams, et al. 2003). Essas temperaturas febris poderiam favorecer o crescimento de bactérias anti- $B d$, como aquelas detectadas nos trabalhos de (Lam et al. 2009).

A partir das propriedades apresentadas acima, poderíamos sugerir que bactérias dérmicas tenham co-evoluído com as espécies de anfíbios, desenvolvendo mecanismos de resistência contra a ação dos peptídeos antimicrobianos e mesmo contra a ação de outras entidades microbianas. Por outro lado, haveria uma ocorrência de espécies bacterianas produtoras de metabólitos antimicrobianos que atuariam como um fator de seleção, determinando os perfis das microbiotas da pele.

O presente trabalho teve por objetivo a identificação do potencial antimicrobiano dos morfotipos de colônias bacterianas isoladas das comunidades cutâneas amostradas, bem como uma análise comparativa da riqueza de comunidades microbianas presentes em anuros coletados em dois diferentes contextos paisagísticos: fragmento e área contínua, além da comparação dessa riqueza entre quatro espécies de anuros: Proceratophrys boiei, família Cicloramphidae, Dendropsophus minutus, família Hylidae, Aplastodiscus leucopygius, família Hylidae e Phyllomedusa distincta, família Hylidae. Para isso, partimos da seguinte hipótese: Animais que mantêm contato com um gradiente microbiológico mais instável, por exemplo, aqueles presentes nos fragmentos, têm uma riqueza e número de táxons com ação 
anti-patógeno na microbiota da pele maior do que aquelas espécies de anfíbios restritas às florestas.

\section{Materiais e métodos}

\subsection{Isolamento dos morfotipos de colônias bacterianas}

Colônias bacterianas foram isoladas das comunidades utilizadas no trabalho de determinação da densidade de microbiota cutânea de anfíbios $\square$ Capítulo1. Para cada área de coleta, morfotipos foram isolados das espécies: Proceratoprhys boiei, Aplastpdiscus leucopygius, Phyllomedusa distincta e Dendropsophus minutus. Dessa forma, entidades das comunidades microbianas foram isoladas não só conforme as espécies, mas também destas em localidades diferentes. Após a contagem, a placa foi reservada para o isolamento das colônias, em laboratório. As colônias foram caracterizadas de acordo com a morfologia observada com o auxílio de uma lupa da marca (Quimis®). Foram utilizadas para caracterização: cor, borda, tamanho, brilho, superfície (lisa ou rugosa) e outros aspectos que saltasse aos olhos, por exemplo, a presença de grânulos. Foi denominado morfotipo uma colônia representante de um grupo de colônias com as mesmas características morfológicas. Em uma capela de fluxo laminar (GermFree Laboratories Inc.), as colônias foram transferidas para novo meio R2A (DIFCO) e isoladas pelo método do esgotamento em placa,com o auxílio de uma alça de platina, previamente esterilizada em uma chama de bico de bunsen, , como descrito em Madigan et al., 2009. As colônias isoladas, foram a seguir inoculadas em meio de cultura R2A sólido, em tubo inclinado para seu armazenamento. Uma pequena coleção microbiológica foi criada: todos os tubos contendo os morfotipos isolados foram estocados em geladeira a $8^{\circ} \mathrm{C}$ e repicados a cada seis meses, para que a viabilidade dos mesmos se mantivesse durante e após os experimentos. A cada um dos morfotipos foi 
atribuído um código de identificação que permite o resgate das informações sobre a sua procedência. A denominação RG informa que esse isolado é procedente do município de Ribeirão Grande, INT, Fazenda Paraíso do Parque Estadual de Intervales, SLP, São Luís do Paraitinga e NSV, Núcleo de Santa Virgínia. Os dois primeiros números fazem referência à espécime de anuro utilizada e os últimos em referência ao isolado.

Os registros morfológicos dos isolados foram feitos por fotografia sobre lupa e para a verificação da pureza dos cultivos, microscopia por coloração de GRAM. As imagens foram feitas de maneira a ressaltar algumas características morfológicas, de acordo com os padrões de descrição definidos por Eaton et al., 1995 e Ogram \& Feng, 1997, onde observase principalmente formato, borda, textura, coloração e diâmetro da colônia. Foi utilizado o teste Kruskall-Wallis para as análises dos números totais de morfotipos isolados das comunidades microbianas das quatro espécies de anuros.

\subsection{Inibição de crescimento bacteriano}

O método do "traço cruzado" (do inglês cross-streak), primeiramente utilizado por Alexander Flemming (1881-1955) nos estudos da penicilina, hoje é bastante empregado nas pesquisas de microbiologia industrial durante a busca por novos antibióticos e os espectros de ação destes (Madigan et al., 2009).

As cepas de referência usadas nos testes foram cedidos pela Fundação Oswaldo Cruz - Fiocruz / RJ. Foram elas: Cocos Gram-positivos: Staphylococcus aureus - ATCC 14458; Staphylococcus epidermidis - ATCC 12228 e Micrococcus luteus - ATCC 7468. Bacilos Gram-negativos: Escherichia coli - ATCC 11229; Proteus vulgaris - CCUG 10784; Salmonella enterica subsp. enterica serovar Typhi-ATCC 6539; Salmonella enterica subsp. enterica serovar Enteritidis(CT) - ATCC 13076; Aeromonas hydrophila- 
IOC/FDA 110-36; Pseudomonas aeruginosa - ATCC 15442 e Klebsiella pneumoniae subsp. pneumoniae - ATCC 4352. Esses patógenos foram escolhidos após uma revisão na literatura acerca das espécies de microrganismos que afetam anfíbios e em concordância com os patógenos utilizados nos testes de capacidade antimicrobiana com isolados de outras espécies de anfíbios (Ashcroft, 2008). O fungo quitrídio Batrachochytrium dendrobatidis não foi incluído neste estudo devido à impossibilidade de obtenção de cepas de referência, uma vez que, no Brasil, esse patógeno não foi depositado. A importanção de cepas se tornou inviável pelo tempo que seria gasto com a tramitação do processo junto aos órgãos responsáveis. Além disso, resultados mais expressivos deveriam ser obtidos com cepas isoladas de anfíbios brasileiros, devido à possível variação fenotípica, quando comparadas àquelas de outras regiões.

O método de traço cruzado consistiu em inocular um novo microrganismo isolado da pele dos animais em um dos lados da placa, permitindo o crescimento deste à temperatura ambiente, até que a região inoculada seja coberta por uma massa de células detectada a olho nu (Figura 1A). A seguir, foram inoculadas as bactérias cuja sensibilidade foi avaliada, ou seja, os patógenos. Estas foram inoculadas em traços perpendiculares e ao lado oposto próximo à massa da bactéria isolada dos animais (Figura 1B). Após 24 horas de incubação, em temperatura ambiente, foi observado o crescimento, o indicativo da produção de antibióticos é a falta de crescimento dos traços na região próxima à massa de crescimento do microrganismo produtor (Madigan et al., 2009).

Foi demarcado um traço na linha média da placa de Petri, próximo a bactéria isolada dos anuros. Um segundo traço determinava o ponto inicial do inóculos das bactérias a serem inibidas. Um terceiro traço demarcava o limite de crescimento para ser considerada a inibição, ou seja, quando o crescimento não ultrapassou a terceira linha, foi considerada a 
inibição do crescimento (Figura 1). Foram realizados controles nos quais foram inoculados na ausência de um microrganismo isolado de anuros para verificação da viabilidade dos patógenos nas condições de crescimento.

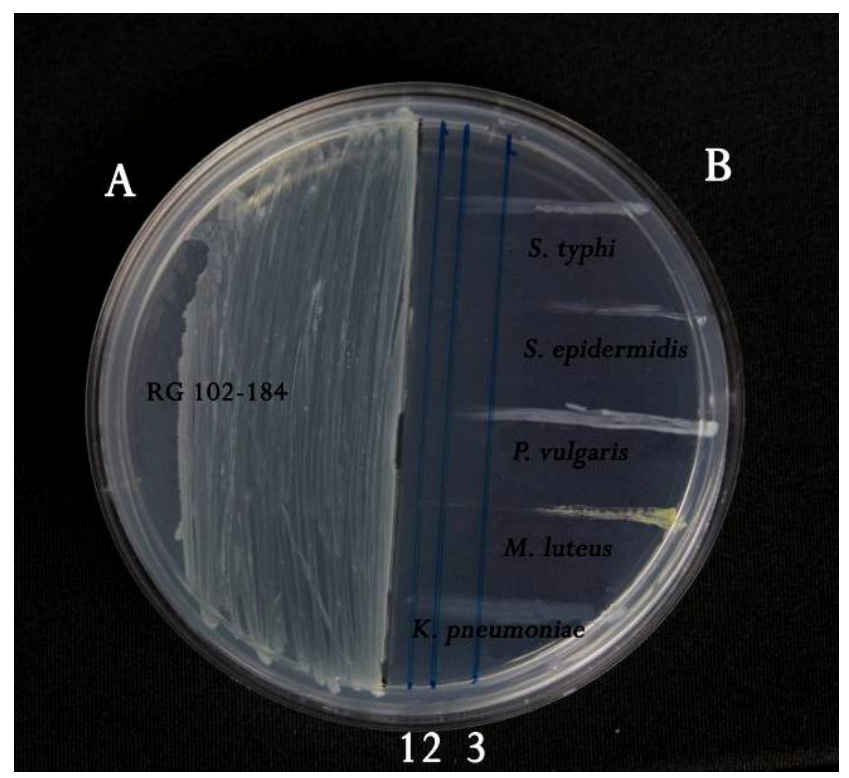

Figura 1. Método do traço cruzado utilizado para identificar colônias isoladas dos anuros com atividade anti-microbiana. A) colônia isolada da pele de anuro B) patógenos em traço perpendicular à bactéria do anuro c) traços para análise do crescimento dos patógenos.

\section{Resultados}

\subsection{Morfotipos}

Obtivemos um total de 214 morfotipos bacterianos isolados das espécies Proceratophrys boiei, Aplastodiscus leucopygius, Phyllomedusa distincta e Dendropsophus minutus. Foram utilizados os cultivos das comunidades feitos no trabalho anterior (Capítulo 1). As colônias isoladas foram registradas por meio de fotografia sobre lupa. Exemplos dos registros feitos constam na figura 1. Após essa etapa, foi criado um banco microbiológico onde estão depositados todos os isolados de colônias bacterianas obtidas da microbiota cutânea dos anuros estudados, dessa forma, esses microrganismos estão disponibilizados para trabalhos de diferentes grupos de pesquisa. Vale mencionar que alguns não se 
mativeram viáveis após os repliques, feitos a cada seis meses, havendo hoje um total de 161 isolados.
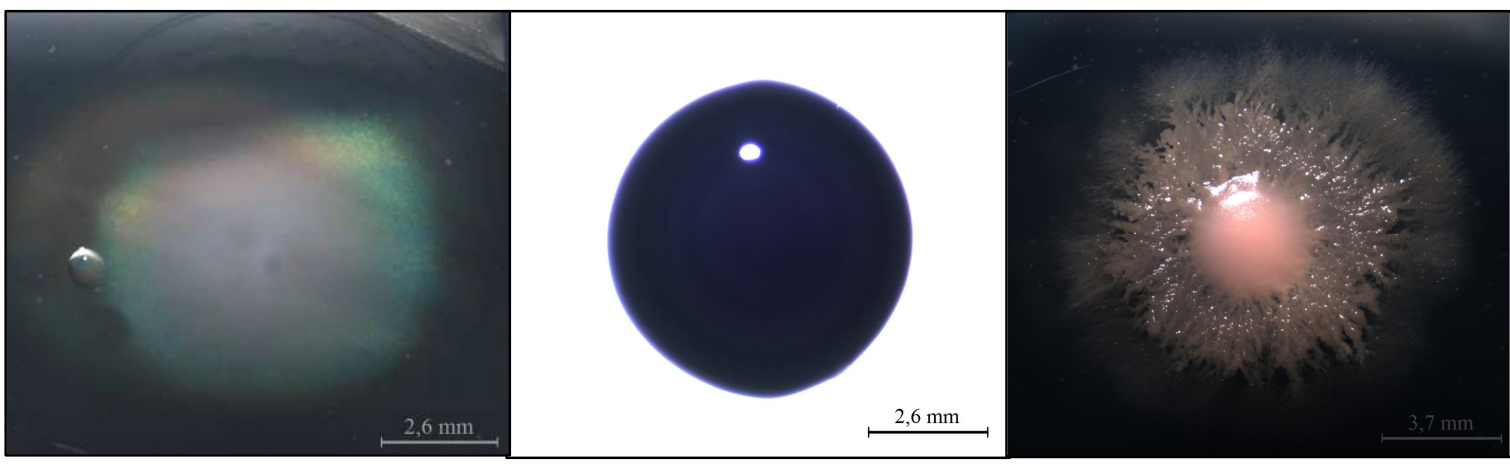

Figura 1. Exemplos de registros fotográficos feitos a partir dos morfotipos de colônias bacterianas isoladas das microbiotas residentes de anfíbios.

\subsection{Densidade de morfotipos}

Foi constatado que há diferenças significativas entre as espécies $\left(p=1,20^{-3}\right)$. Sendo $P$. boiei a espécie com maior riqueza da qual foram isolados, seguido de $P$. distincta, D. minutus e A. leucopygius (Figura 2).

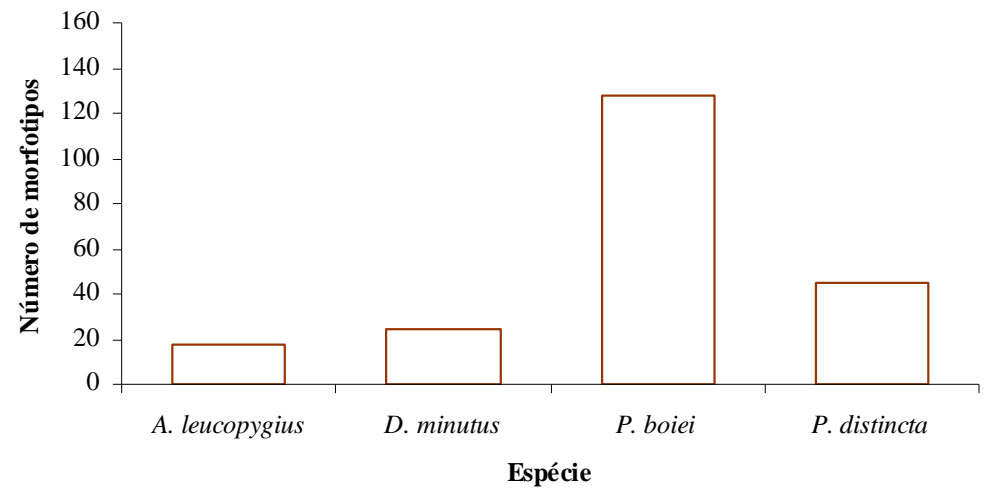

Figura 2 - Número de morfotipos de colônias bacterianas isoladas em quatro espécies de anuros.

Uma comparação feita entre as médias de morfotipos de colônias bacterianas amostradas de animais em áreas contínuas (DP 1,87) e fragmentadas (DP 5,165; p= 6,04 $4^{-1}$ ) 
mostrou que não há diferença significativa entre elas (Figura 3), o que pode ser consequiência das medidas de dispersão observadas. Apesar disso, o número total de morfotipos quase duplica nas áreas fragmentadas (149) em relação às áreas contínuas (61).

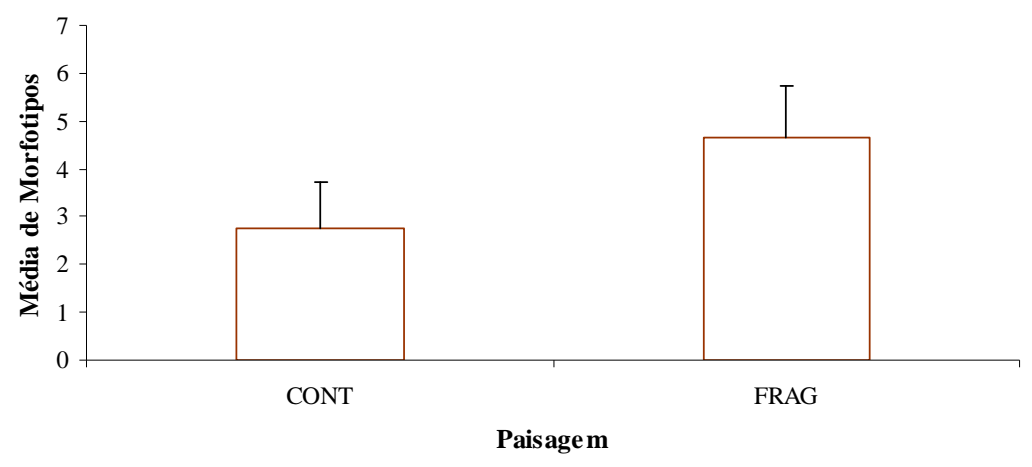

Figura 3. Média do número total de morfotipos de colônias bacterianas isoladas em áreas contínuas e fragmentos. CONT são áreas contínuas e FRAG são fragmentos.

Houve diferença significativa entre os números totais de morfotipos isolados de comunidades microbianas das quatro espécies de anuros, acima citadas, em diferentes localidades $\left(p=4,16^{-2}\right)$ (Figura4).

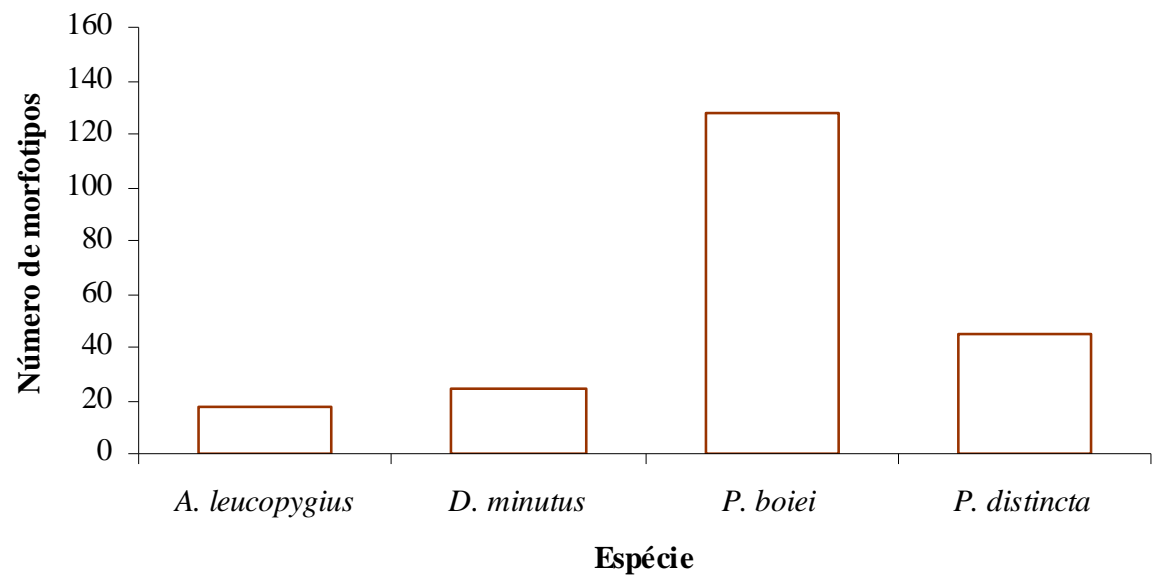

Figura 4 - Número de morfotipos de colônias bacterianas isoladas em quatro de anfíbios em quatro áreas de amostragem. INT, Intervales; NSV, Núcleo de Santa Virgínia; RG, Ribeirão Grande; SLP, São Luís do Paraitinga. 


\subsection{Ensaio de poder inibitório de patógenos}

Todos os morfotipos bacterianos isolados e que se mantiveram em nosso banco microbiológico, um total de 161, dos quais 27 apresentaram poder inibitório contra pelos menos um dos 10 patógenos utilizados. Proceratophrys boiei foi a espécie para a qual mais isolados inibidores foram identificados (17), seguida de Phyllomedusa distincta (4) e, depois, Dendropsophus minutus (3) e Aplastodiscus leucopygius (3) (Tabela 1). Os controles apresentaram crescimento de acordo com o esperado.

As cepas padrão ATCC (American Type Culture Collection), que sofreram inibição por um maior número de cepas isoladas foram: Staphyllococcus aureus (16) e Streptococcus epidermidis (17), seguidos de Aeromonas hydrophila (11), Micrococcus luteus (11), Klebisiella pneumoniae (8), Proteus vulgaris (5), Salmonella typhi (4), Escherichia coli (3), Pseudomonas aeruginosa (3) e, por útlimo, Salmonella enteritidis (1). $\quad$ P. boiei foi a espécie com maior número de morfotipos com poder inibitório, sendo a maior parte dos isolados com potencial contra Staphyllococcus aureus e Streptococcus epidermidis. $\quad$ P. distincta teve isolados com potencial contra cinco do dez patógenos testados, D. minutus possuiu pelo menos um isolado contra praticamente todos os patógenos, com exceção de Salmonella enteritidis, para a qual menos isolados tiveram efeito. A. leucopugius, assim, como $P$. distincta também teve isolados com efeitos inibitórios para cinco dos dez patógenos expostos (Tabela 1). 
Tabela 1: Efeito inibitório de morfotipos de colônia bacteriana isoladas de espécies de anfíbios, para cada patógeno testado.

\begin{tabular}{|c|c|c|c|c|c|c|c|c|c|c|c|c|}
\hline Espécie de anfíbio & Morfotipo & EC & $\mathbf{A H}$ & PA & AS & SENT & ST & SEP & PV & ML & $\mathbf{K P}$ & Total \\
\hline \multirow{17}{*}{$\begin{array}{l}\text { Proceratophrys boiei } \\
-17 \text { morfotipos - }\end{array}$} & SLP2-14 & $*$ & * & $*$ & $*$ & $*$ & $*$ & $*$ & $*$ & $*$ & $*$ & 10 \\
\hline & SLP 124-196 & $*$ & - & $*$ & $*$ & - & $*$ & - & - & $*$ & $*$ & 6 \\
\hline & RG58-132 & - & $*$ & - & $*$ & - & - & $*$ & - & $*$ & - & 4 \\
\hline & RG31-95 & $*$ & $*$ & - & $*$ & - & - & $*$ & - & - & - & 4 \\
\hline & SLP124-195 & - & - & - & - & - & - & $*$ & $*$ & $*$ & $*$ & 4 \\
\hline & SLP3-16 & - & - & - & - & - & - & - & $*$ & $*$ & $*$ & 3 \\
\hline & RG28-51 & - & - & - & $*$ & - & - & - & $*$ & - & $*$ & 3 \\
\hline & SLP150-219 & - & - & - & $*$ & - & - & $*$ & - & $*$ & & 3 \\
\hline & NSV95-167 & - & $*$ & - & $*$ & - & - & $*$ & - & - & - & 3 \\
\hline & NSV95-168 & - & - & - & - & - & - & $*$ & - & $*$ & - & 2 \\
\hline & NSV95-166 & - & - & - & - & - & - & $*$ & - & - & $*$ & 2 \\
\hline & RG58-131 & - & $*$ & - & $*$ & - & - & - & - & - & - & 2 \\
\hline & RG30-87 & - & $*$ & - & - & - & - & - & - & - & - & 1 \\
\hline & RG30-90 & - & - & - & - & - & - & $*$ & - & - & - & 1 \\
\hline & INT70-148 & - & - & - & $*$ & - & - & - & - & - & - & 1 \\
\hline & SLP 124-199 & - & - & - & - & - & - & $*$ & - & - & - & 1 \\
\hline & SLP128-213 & - & - & - & - & - & - & $*$ & - & - & - & 1 \\
\hline \multirow{4}{*}{$\begin{array}{l}\text { Phyllomedusa } \\
\text { distincta } \\
\text { - } 4 \text { morfotipos - }\end{array}$} & INT23-37 & - & - & - & $*$ & - & $*$ & - & - & - & - & 2 \\
\hline & INT26-41 & - & $*$ & - & $*$ & - & - & - & - & - & - & 2 \\
\hline & INT27-42 & - & - & - & $*$ & - & - & - & - & - & - & 1 \\
\hline & RG66-140 & - & - & - & - & - & - & $*$ & - & - & - & 1 \\
\hline \multirow{3}{*}{$\begin{array}{c}\text { Aplastodiscus } \\
\text { leucopygius } \\
-3 \text { morfotipos - }\end{array}$} & NSV99-177 & - & $*$ & - & $*$ & - & - & * & - & $*$ & $*$ & 5 \\
\hline & NSV99-176 & - & $*$ & - & $*$ & - & - & $*$ & - & $*$ & - & 4 \\
\hline & NSV97-172 & - & - & - & - & - & - & $*$ & - & - & - & 1 \\
\hline \multirow{3}{*}{$\begin{array}{l}\text { Dendropsophus } \\
\text { minutus } \\
-3 \text { morfotiopos - }\end{array}$} & RG102-184 & - & $*$ & $*$ & $*$ & - & - & $*$ & $*$ & $*$ & $*$ & 7 \\
\hline & RG102-185 & - & $*$ & - & $*$ & - & - & $*$ & - & $*$ & - & 4 \\
\hline & NSV91-160 & - & - & - & - & - & $*$ & - & - & - & - & 1 \\
\hline
\end{tabular}

Abreviações: EC, Escherichia coli; AH, Aeromonas hydrophila; PA, Pseudomonas aeruginosa; AS, Staphyllococcus aureus; SE, Streptococcus epidermidis; ST, Salmonella typhi; SEP, Streptococcus epidermidis; PV, Proteus vulgaris; ML, Micrococcus luteus; KP, Klebisiella pneumoniae. 
Houve mais bactérias com poder inibitório isoladas de anuros coletados em áreas fragmentadas. Foram 18 isolados destes contra 11 isolados de anuros de áreas contínuas (Figura 5).

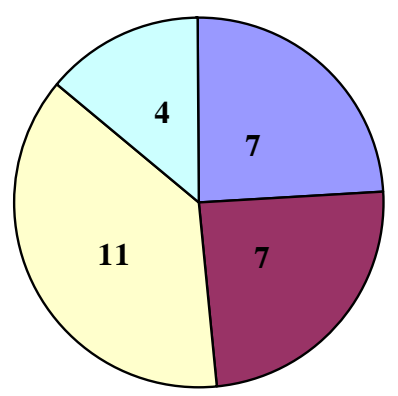

$\square$ São Luís do Paraitinga $\square$ Núcleo de Santa Virgínia $\square$ Ribeirão Grande $\square$ Intervales

Figura 5: Número de isolados com potencial inibitório em áreas de coleta. Sendo áreas fragmentadas: São Luís do Paraitinga e Ribeirão Grande e áreas contínuas: Núcleo de Santa Virgínia e Intervales.

\section{Discussão}

\subsection{Riqueza microbiana}

A espécie que apresentou maior riqueza de morfotipos de colônias bacterianas, Proceratophrys boiei, é também a espécie na qual houve maior densidade microbiana, em nossa primeira abordagem (Capítulo 1). Isso demonstra que essa espécie é um modelo importante nos estudos da microbiota cutânea de anfíbios. Apesar de ainda não é possível apontar os fatores determinantes das diferenças de riqueza microbiana encontradas nas peles desses animais, o microhabitat ocupado e o tipo de pele podem ser bons norteadores. O tegumento de $P$. boiei é bastante rugoso se comparado às outras espécies estudadas, apresentando diversas protuberâncias e verrugas com projeções semelhantes a espinhos, com glândulas mucosas com secreção de glicosaminoglicanos (Felsemburgh et al., 2007). Além disso, essa espécie mantém contato com o solo, que apresenta grande diversidade e 
densidade de entidades microbianas (Atlas \& Bartha, 1993). Esses dois fatores devem determinar maior riqueza de morfotipos encontrada nessa espécie, quando comparada a Phyllomedusa distincta, Dendropsophus minutus e Aplastodiscus leucopygius.

O tipo de solo, água, cobertura vegetal e outros, variam em estrutura física, composição de nutrientes, temperatura e potencial de água o que determinam o tipo de bactéria presente no meio e deve, por conseguinte, determinar a comunidade na epiderme dos anfíbios (Belden \& Harris, 2007). Por tanto, os efeitos das alterações antropogênicas, como aqueles observados quando ocorre no processo de fragmentação de florestas antes contínuas, acarretam alterações na composição da microbiota dos microambientes (Zilli et al., 2003).

\subsection{Efeito inibitório}

Um grande número de morfotipos bacterianos com poder inibitório do crescimento de patógenos foi encontrado. Trabalhos anteriores demonstram a ocorrência de espécies bacterianas com poder antimicrobiano nas espécies de salamandras Plethodon cinereus e Hemidactylus scutatum, e nas espécies de anuros Rana mucosa, Rana sierrae, Notophthalamus viridescens e Lithobates catesbeianus (Harris et al., 2006; Lauer et al., 2007; Culp et al., 2007; .Lauer et al., 2008; Woodhams et al., 2007; Lam et al., 2009) todas de ocorrência dos Estados Unidos da América o que torna difícil a comparação entre essas e as comunidades da presente pesquisa.

A ocorrência de um maior número de morfotipos com poder inibitório em $P$. boiei deve-se à complexidade de morfotipos bacterianos encontrados, que foi superior nesse táxon. Sabemos que o solo abriga grande quantidade de espécies bacterianas produtoras de secreções antimicrobianas (Gottlieb, 1976). Dessa forma, P. boiei que ocupa esse substrato, deve abrigar uma pequena parcela das comunidades que ali vivem. Também foi observado 
um maior número de morfotipos isolados de indivíduos em fragmentos de floresta o que deve ser uma conseqüência da maior riqueza de morfotipos encontrada nessa paisagem. Esse aspecto torna-se importante no contexto da proposta feita por Lam et al., 2009, na qual a proporção de bactérias com poder inibitório do crescimento do fungo $B d$, na espécie de anuro Rana mucosa, é determinante na resistência das populações desses animais contra o fungo patógeno. $\mathrm{O}$ que sugere que as populações de anuros com maior quantidade de morfotipos bacterianos com poder inibitório podem ser mais resistentes quando são expostas a patógenos, no meio natural.

Espécies de patógenos testados já foram identificados como parte das microbiotas residentes da pele de outros anfíbios em trabalhos anteriores, tais como Pseudomonas aeruginosa, e Staphyllococcus epidermidis e a espécie Aeromonas hydrophila (Lauer et al., 2008; Culp et al., 2007). O gênero Salmonella já foi detectado em casos de infecção em anuros (Densmore \& Green, 2007). A ocorrência de entidades bacterianas com poder inibitório contra esses patógenos retrata a importância dessa comunidade como primeira proteção.

\section{Conclusão}

O estudo da riqueza dos morfotipos bacterianos ressaltou a complexidade das comunidades microbianas na pele dos anfíbios estudados. Ressaltou ainda a existência de perfis de comunidades inerentes a cada espécie, havendo maior complexidade em $P$. boiei, seguida de $P$. distincta, A. leucopygius e, por fim $D$. minutus. O perfil microbiológico da pele de anfíbios se perfila como fundamental na biologia da conservação de anuros, no entanto, os fatores que ditam as variações na microbiota da epiderme em populações de anfíbios anuros 
não têm recebido atenção. Especula-se que atributos biológicos, história de vida, fatores genéticos e seleção natural podem determinar essas variações na composição da comunidade microbiana, mas o papel do microclima com as suas conseqüências ecofisiológicas não têm sido estudado. É possível que a comunidade microbiana presente nos microhabitats de florestas sofre algum grau de perturbação quando ocorre a fragmentação dos habitas e, como verificado no presente estudo, é possível que tal perturbação se estenda à microbiota cutânea doa anfíbios, ditando uma maior complexidade, como observado.

Os efeitos observados podem ser diferentes entre espécies, e mesmo entre paisagens com características gerais similares. Este trabalho é um primeiro passo no esclarecimento dessas relações, e a identificação dos morfotipos é um passo seguinte importante para entender como mudam as comunidades microbianas cutâneas de anuros nas paisagens. Nessa perspectiva, a própria pele dos anfíbios, como microhabitat de uma comunidade que nela habita, deve ser considerada, pois, pode sofrer modificações derivadas de fatores ecofisiológicos como temperatura, estado hídrico do indivíduo e outros.

O comprovando poder inibitório do crescimento de patógenos neste trabalho ressalta a importância dessas comunidades como primeira proteção contra agentes infecciosos. Assim, torna-se indispensável entendermos de que forma as condições ambientais e fatores inerentes ao organismo influenciam a microbiota cutânea dos anfíbios, para começarmos a entender quais espécies ou ainda quais condições deixariam as espécies mais vulneráveis às infecções, caso a estrutura das comunidades microbianas da pele fossem alteradas. 


\section{Capítulo 3}

Identificação de morfotipos de colônias bacterianas isoladas de comunidades microbianas residentes da pele de quatro anuros da Floresta Atlântica 


\section{Resumo}

Os anfíbios abrigam uma microbiota cutânea complexa e que determinados componentes dessas comunidades têm efeito comprovado in vitro contra alguns patógenos conhecidos. Estudos de caracterização da microbiota cutânea de anfíbios, porém, são escassos e os trabalhos existentes são recentes. A identificação taxonômica e funcional dos componentes das microbiotas é o passo inicial para futuras elucidações de relações patógenohospedeiro, além do entendimento da estrutura e funcionalidade das comunidades estabelecidas sobre dos anfíbios, estabelecendo a interface pele - comunidade microbiana. Além disso, a diversidade microbiana presente na pele dos anuros pode ser importante fator determinante na ocorrência de doenças cutâneas. Neste trabalho, tivemos por objetivo a identificação de morfotipos de colônias bacterianas isoladas das comunidades microbianas em estudo, assim como a busca por padrões que pudessem ser detectados a partir da determinação taxonômica desses isolados. Foram identificados 68 isolados de morfotipos de colônias bacterianas. Entre os quais houve predominância de bactérias dos filos Proteobacteria, Firmicutes, Bacteroidetes e Actinobacteria, típicas de ambiente, o que corrobora nossa idéia central do papel do ambiente na composição das comunidades microbianas da pele dos anfíbios. 


\section{Introdução}

Estudos que confirmam a existência de uma comunidade microbiana residente na pele dos anfíbios são recentes. As primeiras menções se deram sob a perspectiva do possível significado dessas comunidades durante o cuidado parental em espécies de urodelos (Bettin \& Greven, 1986). Mais tarde, foi constatada presença de bactérias produtoras de antibióticos que tinha ação contra o crescimento de fungos como Mariannaea sp., que atacam os ovos das fêmeas da salamandra (Harris et al., 2006). A partir disso, cada vez mais são publicados estudos explorando o potencial da microbiota cutânea de anfíbios contra agentes patogênicos e, com isso, a diversidade bacteriana e os perfis dessas comunidades têm sido revelados. Lauer et al., 2007, identificou 14 espécies bacterianas residentes da pele da salamadra Plethodon cinereus. Em 2008, Lauer e colaboradores identificaram 48 espécies de bactérias cutâneas pertencentes a 16 gêneros e 14 famílias, na salamandra Hemidactylium scutatum. Nesse mesmo trabalho, onde se comparou a composição da microbiota cutânea de $H$. scutatum com Plethodon cinereus, verificou-se que a proporção de espécies bacterianas compartilhadas diminuía conforme a hierarquia taxonômica. Assim, haviam quatro filos compartilhados (100\% do total), sete famílias (53\%), nove gêneros (47\%) e oito espécies (10\%). Por isso, foi sugerido que pode haver especificidade de espécies bactérias para com espécies de anfíbios (Lauer et al., 2008).

Estes estudos elucidam o caráter inicial da pesquisa em microbiota cutânea de anfíbios. Investigações sobre a diversidade dessas comunidades são indispensáveis nesse momento, pois, é primordial ter o conhecimento sobre quais táxons compõem essas comunidades e se há padrões. 
O substrato é um importante determinante dos perfis das comunidades microbianas que sobre ele se estabelecem (Atlas \& Bartha, 1993). A pele dos anfíbios como um substrato, pode ser um meio bastante seletivo devido principalmente às características morfológicas e fisiológicas inerentes a cada espécie desses vertebrados. Tais como, secreções de peptídeos antimicrobianos, carboidratos, ceras e mucos (Ashcroft et al. 2007). Os perfis das comunidades residentes na pele dos anuros também podem ser influenciados pela estrutura da comunidade microbiana presente no ambiente, e por sua vez, influenciada por variáveis químicas e físicas (Pelczar et al., 1981; Madigan et al., 2004). Além disso, a própria interação da comunidade estabelecida com potenciais colonizadores do ambiente poderia delimitar o perfil da comunidade (Mangoni et al., 2001; Rollins-Smith et al., 2002). Nesse aspecto, há indícios de que a comunidade residente seja um fator estimulante para a produção dos próprios peptídeos (Mangoni et al., 2001; Barbosa, 2010).

Doenças causadas por espécies microbianas oportunistas podem ser deflagradas mediante as mudanças em variáveis ambientais, que determinam eventos de imunossupressão (Carey et al, 1999). No entanto, pouco se sabe sobre as relações microrganismo/hospedeiro que se estabelecem entre micro e macrorganismos, no mundo natural. Sabemos que anfíbios abrigam uma microbiota cutânea complexa e que determinados componentes dessas comunidades têm efeito comprovado in vitro contra alguns patógenos conhecidos (Harris et al., 2006; Woodhams et al., 2007; Lauer et al., 2007). A identificação taxonômica e funcional dos componentes das microbiotas é o passo inicial para futuras elucidações de relações patógeno-hospedeiro estabelecidas na interface pele - comunidade microbiana. Além disso, a diversidade microbiana presente na pele dos anuros pode ser importante fator determinante na ocorrência de doenças cutâneas. 
No decorrer da pesquisa, isolamos bactérias da comunidade da derme dos anuros estudados e caracterizamos a atividade antibacteriana de alguns dos morfotipos. No presente trabalho tivemos por objetivo a identificação de morfotipos de colônias bacterianas isoladas das comunidades microbianas em estudo, assim como a busca por padrões que pudessem ser detectados a partir da determinação taxonômica desses isolados.

\section{Materiais e métodos}

\subsection{Identificação dos isolados bacterianos}

Para identificação por sequenciamento e análise filogenética do gene de RNAr $16 \mathrm{~S}$, as colônias foram coletadas diretamente das placas de cultivos puros e colocadas diretamente na reação de amplificação. Um fragmento específico do gene 16S rRNA foi amplificado com os oligonucleotídeos iniciadores P338F (5' ACTCCTACGGGAGGCAGCAG-3') e W031R (5'-TTACCGCGGCTGCTGGCAC-3'), (Khammar et al., 2005; Xia et al., 2005). Cada reação foi realizada com tampão para Taq DNA polimerase (Tris $\mathrm{HCl} 20 \mathrm{mM} \mathrm{pH} 8.0, \mathrm{KCl} 500 \mathrm{mM}$ ), dNTPs a $0,25 \mu \mathrm{M}$, cada oligonucleotídeo a 0,25 $\mu \mathrm{M}, \mathrm{MgCl}_{2}$ a 1,5 mM, 1,5 unidades de Taq DNA polimerase. Para cada isolado, foi coletada uma única colônia com o auxílio de um palito de madeira estéril e imersa na solução da reação. As condições da PCR foram as seguintes: uma etapa de desnaturação inicial a $94^{\circ} \mathrm{C}$ por 5 min, seguida de 30 ciclos de $94^{\circ} \mathrm{C}$ durante $1 \mathrm{~min}, 61^{\circ} \mathrm{C}$ por 1 min para o anelamento e, finalmente, $72^{\circ} \mathrm{C}$ durante $30 \mathrm{seg}$ e $72^{\circ} \mathrm{C}$ durante $10 \mathrm{~min}$, para elongação. O resultado da amplificação foi constatado por eletroforese em gel de agarose $2 \%$, contendo brometo de etídio $(0,5 \mu \mathrm{g} / \mathrm{mL})$, em TAE (Tris-acetato $40 \mathrm{mM}$, EDTA $1 \mathrm{mM}$ ) e posterior observação das bandas de DNA sobre transluminador UV $260 \mathrm{~nm}$ (Sambrock et al., 1989), das bandas com 130 pares de base, aproximadamente. 


\subsection{Clonagem}

\section{Ligação}

Os produtos de PCR foram clonados utilizando o vetor comercial pGEM $^{\circledR}$-T Easy (50ng), de acordo com as instruções suplementares do fabricante (Promega), utilizando 0,5 $\mu \mathrm{L}$ de inserto, contendo aproximadamente 10 ng de DNA amplificado.

\section{Preparo de bactéria competente}

Células bacterianas de E.coli da linhagem SURE foram inoculadas over-night em $10 \mathrm{~mL}$ de meio de cultivo SOB (Triptona 2\%, Exrato de levedura 0,5\%, $\mathrm{NaCl} 10 \mathrm{mM}, \mathrm{KCl}$ 2,5 mM, MgCl2 10mM, MgSO4 10mM pH 6.8 - 7.0). O volume de 10 mL deste pré-inóculo foi adicionado a $100 \mathrm{~mL}$ do mesmo meio de cultivo e incubado a $37^{\circ} \mathrm{C}$, com agitação moderada até atingir uma DO entre 0,4 e 0,6 (A - 595nm). As células foram colhidas em tubos de $50 \mathrm{~mL}$, incubadas em gelo por 10 min e então centrifugadas a $3000 \mathrm{rpm}$, por $10 \mathrm{~min}$ a $4^{\circ} \mathrm{C}$. Após o descarte do sobrenadante, o precipitado foi ressuspendido em $33 \mathrm{~mL}$ em FSB - Frozen Storage Buffer - (Acetato de potássio 1M pH 7.5, Glicerol 10\%, KCl 100mM, $\mathrm{MnCl}_{2} .2 \mathrm{H}_{2} \mathrm{O} 45 \mathrm{mM}, \mathrm{CaCl}_{2} .2 \mathrm{H}_{2} \mathrm{O} 10 \mathrm{mM}, \mathrm{HACoCl}_{3}$ ) e incubado em gelo por $10 \mathrm{~min}$. As células foram precipitadas por centrifugação a $3000 \mathrm{rpm}$, por 10 min a $4^{\circ} \mathrm{C}$ e as células ressuspendidas em $8 \mathrm{~mL}$ de FBS. Foram adicionados $280 \mu \mathrm{L}$ de DMSO (concentração final 3,5\%) e, depois uma incubação em gelo por 5 min, mais $280 \mu \mathrm{L}$ de DMSO (concentração final 7,0\%) foram adicionados e mais uma incubação foi feita em gelo, por 10 min. Alíquotas de $200 \mu \mathrm{L}$ foram banhadas em gelo seco-etanol e então preservadas em freezer a $-80^{\circ} \mathrm{C}$ (Sambrock et al., 1989).

\section{Transformação de bactérias por choque térmico}

À suspensão de células competentes, preparadas pelo protocolo acima, foram adicionadas as reações de ligação inserto-vetor. Após 10 min de incubação em gelo, foi 
realizado um choque térmico em banho-maria a $42^{\circ} \mathrm{C}$ por $90 \mathrm{seg}$. Uma incubação a $37^{\circ} \mathrm{C}$ de 45 min foi feita em meio líquido $\mathrm{SOB}$ e a seguir os as células foram inoculadas em meio sólido SOB (ágar 2\%) contendo Ampicilina $100 \mu \mathrm{g} / \mathrm{mL}$, IPTG $30 \mu \mathrm{g} / \mathrm{mL}$ e X-gal $70 \mu \mathrm{g} / \mathrm{mL}$, seguida da incubação destas placas a $37^{\circ} \mathrm{C}$, over-night (Sambrook et al., 1989). Um indicativo de que o inserto de interesse foi acoplado ao vetor é a coloração branca da colônia bacteriana observada na placa. A inserção do fragmento implica na inativação do gene lacZ e a formação de colônias brancas (recombinantes) que são incapazes de metabolizar o X-gal, por não produzirem a enzima $\beta$-galactosidase, que cliva esse componente e produz colônias de cor azul de índigo. Os clones não recombinantes possuem esse gene ativo sendo capazes de transcrever e traduzir a enzima, o que torna as colônias azuis.

\section{Extração de DNA plasmidial}

Foram feitas extrações de pequena escala, "mini-prep", com modificações do protocolo proposto por Birnboim e Doly, em 1979. Para cada cultivo de bactérias transformadas, como protocolo descrito acima, três colônias brancas foram coletadas e inoculadas, separadamente, em $3 \mathrm{~mL}$ de meio LB (Triptona 1\%, Extrato de levedura 5\%, $\mathrm{NaCl}$ 1\%) com $100 \mu \mathrm{g} / \mathrm{mL}$ de ampicilina (LB-AMP) e crescidas over-night com agitação de $250 \mathrm{rpm}$, a $37^{\circ} \mathrm{C}$. Para cada cultivo, $1,5 \mathrm{~mL}$ foram transferidos para tubos tipo cônicos de centrífuga (eppendorf) e centrifugados a $12000 \mathrm{rpm}$, durante 1 min à temperatura ambiente. O sobrenadante foi descartado e o sedimento ressuspendido em $300 \mu \mathrm{L}$ de solução P1 (Tris/HCl 50mM, EDTA 10mM pH 8.0 e RNAse $10 \mu \mathrm{g} / \mathrm{mL}$ ) com homogeneização por inversão. Por conseguinte, a solução P2 (NaOH 200 mM, SDS 10\%) foi adicionada e homogeneizada por inversão e incubada por 5 min à temperatura ambiente. Após esse tempo foi acrescentada a solução P3 (Acetato de potássio 5M, Ácido acético glacial pH 5.5) gelada 
e nova homogeneização foi feita, seguida de uma centrifugação a 12000 rpm, durante 10 min

a $4^{\circ} \mathrm{C}$. O sobrenadante foi recuperado e o DNA plasmidial precipitado com $600 \mu \mathrm{L}$ de isopropanol, seguido de centrifugação a $14000 \mathrm{rpm}$, durante 15 min a $4^{\circ} \mathrm{C}$. O sobrenadante foi retirado e o precipitado lavado em etanol 70\%. Após centrifugação a 14000 rpm, durante 10 min a $4^{\circ} \mathrm{C}$, o álcool foi descartado e após a secagem do sedimento foi adicionado $50 \mu \mathrm{L}$ de TE (Tris 10 mM pH 7.5, EDTA $1 \mathrm{mM}$ ) ou água e manutenção em geladeira $8^{\circ} \mathrm{C}$.

Para confirmar se os clones receberam o inserto de interesse foi feito um ensaio de restrição, seguindo as recomendações do fabricante (Fermentas Life Sciences), com a endonuclease EcoRI, enzima que proporciona a liberação do fragmento. A visualização dos fragmentos foi feita em gel de agarose (2\%) sobre transluminador UV.

\subsection{Determinação da seqüência de nucleotídeo e análise filogenética}

O preparo para o seqüenciamento dos fragmentos obtidos foi realizado com modificações do protocolo proposto por Sanger e Coulson, em 1975. Foi utilizado o kit de reação BigDye®Terminator v3.1 Cycle Sequencing, seguindo as recomendações do fabricante (Applied Biosystems). As reações foram fracionadas no aparelho ABI PRISM® 3100 Genetic Analyzer/HITACHI, utilizando o serviço do Instituto de Química, Universidade de São Paulo - IQUSP. As seqüências resultantes foram editadas e preparadas para análise utilizando-se o software BioEdit (Hall, 1999). Análise filogenética foi realizada comparando-se as seqüências obtidas com as depositadas nos banco de dados do National Center for Biotechnology Information - NCBI - (2010) e Ribossomal Database Project, release 10 - RDP-X.

Seqüências obtidas nesse estudo assim como seqüências obtidas no banco de dados foram alinhadas utilizando-se o servidor NAST disponível no site Greengenes 
(DeSantis et al., 2006). Os dendogramas foram construídos com o auxílio do software MEGA -5, utilizando-se o método de Neighbor joining com análise de bootstratping com 1000 repetições.

\section{Resultados}

Foram identificadas, por seqüenciamento e análise filogenética do gene do RNAr 16S, 68 isolados de morfotipos de colônias bacterianas, o que corresponde a $34,1 \%$ do total de isolados depositados inicialmente em nossa coleção. Foram priorizados os morfotipos que apresentaram efeito inibitório (Capítulo 2) e que ainda eram viáveis no banco microbiológico, depois, foram escolhidos mais isolados por espécie, priorizando os morfotipos mais diferenciados, em termos de aparência, para maximizar a diversidade. O tamanho das seqüências obtidas variou entre 125 e 158 pares de base permitindo identificação para o nível de família, na maioria dos casos, ou ainda gênero. Foram identificadas 33 isolados (25,8\% do total), 12 famílias e 10 gêneros bacterianos para a espécie Proceratophrys boiei; 11 isolados (61\%), 7 famílias e 2 gêneros para a espécie Aplastodiscus leucopygius 15 isolados (35,7\%), 7 famílias e 6 gêneros para Phyllomedusa distincta e 10 isolados (38,5\%), 5 famílias e 3 gêneros para Dendropsophus minutus A lista completa, contendo o código de identificação dos morfotipos, número de pares de base obtidos, seqüência tipo próximas, porcentagem de similaridade e a classificação consta no Anexo 1, para cada espécie de anfíbio.

Apenas bactérias pertencentes às famílias Microbacteriaceae (filo Actinobacteria) e Pseudomonadaceae (filo Proteobacteria) foram detectados em todos os animais estudados. $P$. boiei apresentou o maior número de famílias exclusivas (37,5\%), assim como a maior riqueza de famílias. A. leucopygius e $P$ distincta apresentaram apenas duas famílias que não foram 
detectadas nas demais espécies e D. minutus apenas uma única família (Tabela1). Além disso, a maioria dos isolados identificados foram pertencentes ao filo Proteobacteria (Anexos, figuras 1-4).

Tabela 1. Famílias de bactérias identificadas por espécies de anuro.

\begin{tabular}{lcccc}
\hline \multicolumn{1}{c}{ Família } & \multicolumn{5}{c}{ Espécie } \\
\cline { 2 - 5 } & P. boiei & leucopygius & distincta & minutus \\
\hline 1.Xanthomonadaceae & 4 & - & - & - \\
2. Brucellaceae & 1 & - & - & - \\
3. Enterobacteriaceae & 4 & 3 & 8 & - \\
4.Erythrobacteraceae & 1 & - & - & - \\
5. Microbacteriaceae & 4 & 1 & 1 & 1 \\
6. Nocardiaceae & 2 & - & - & \\
7. Pseudomonadaceae & 4 & 3 & 2 & 1 \\
8. Sphingobacteriaceae & 2 & 1 & 1 & - \\
9. Flavobacteriaceae & 4 & - & - & - \\
10. Comamonadaceae & 2 & - & - & - \\
11. Moraxellaceae & 2 & 1 & 1 & - \\
12. Bacillaceae & 2 & - & 1 & 6 \\
13. Staphylococcaceae & - & 1 & - & - \\
14. Cellulomonadaceae & - & 1 & - & - \\
15. Patulibacteraceae & - & - & 1 & - \\
16. Oxalobacteraceae & - & - & - & 2 \\
\hline
\end{tabular}

Obs.: Os números indicam a quantidade de morfotipos para cada família identificada.

\section{Discussão}

O presente estudo incluiu apenas espécies da Floresta Atlântica do Brasil, a saber, Proceratophrys boiei, Aplastodiscus leucopygius, Phyllomedusa distincta e Dendropsophus minutus. Nossos resultados sugerem relação entre a microbiota cutânea dessas espécies e de outras que são típicas da América do Norte, por exemplo, Hemidactylium scutatum (Harris et al., 2006; Lauer et al., 2008); Rana mucosa (Woodhams et al., 2007; Lam et al., 2009), Rana 
sierrae (Lam et al., 2009), Notophthalamus viridescens (Culp et al., 2007), Rana catesbieana (Culp et al., 2007). Nesses trabalhos algumas das bactérias observadas foram comuns às bactérias observadas nos anuros da Floresta Atlântica do Brasil.

Esse fato pode ser interpretado sob alguns pontos de vista, que não são exclusivos. Primeiro, é possível que exista ampla distribuição de táxons microbianos componentes das comunidades cutâneas de anfíbios ao longo de grandes distâncias geográficas. Por outro lado, é possível que a pele dos anfíbios, independente da localização geográfica, seja particularmente favorável para o estabelecimento de táxons parecidos, independentemente da espécie hospedeira. A observação acima envolve grandes padrões sistemáticos e não sinaliza ausência de especificidade entre espécies.

Comparando ainda os táxons bacterianos dos anfíbios do presente estudo com estudos anteriores (Harris et al., 2006; Lauer et al., 2008; Woodhams et al., 2007; Lam et al., 2009; Lam et al., 2009; Culp et al., 2007), foi possível constatar que há certa especificidade, pelo menos no nível de família ou gênero. Em P. boiei, por exemplo, o gênero Camamonas e as famílias Brucellaceae, Erythrobacteraceae e Nocardiaceae ocorreram somente nessa espécie. Para A. leucopygius, apenas Staphylococcus foi específico. P. distincta apresentou Cedecea e Patulibacter, como gêneros específicos. D. minutus não apresentou táxons que não ocorreram em outras espécies de anfíbios (Tabela 2). Talvez uma análise comparativa no nível de espécie bacteriana, poderia aumentar o grau de especificidade para com as espécies de anfíbios, como foi demonstrado por Lauer e colaboradores em 2008, ao compararem duas espécies de salamandras. 
Tabela 2.Tabela comparativa das famílias e gêneros de bactérias cutâneas identificadas neste e outros estudos.

\begin{tabular}{|c|c|c|c|c|c|c|c|c|c|c|c|}
\hline Família & Gênero & $\begin{array}{c}1 \\
\text { P. boiei } \\
\end{array}$ & $\begin{array}{c}1 \\
\text { A. leucopygius }\end{array}$ & $\begin{array}{c}1 \\
\text { P. distincta }\end{array}$ & $\begin{array}{c}1 \\
\text { D. minutus }\end{array}$ & $\begin{array}{c}2-3-4-8 \\
\text { P. cinereus } \\
\end{array}$ & $\begin{array}{c}2-5 \\
\text { H. scutatum } \\
\end{array}$ & $\begin{array}{c}\text { 6-7 } \\
\text { R. mucosa } \\
\end{array}$ & $\begin{array}{c}7 \\
\text { R. sierrae } \\
\end{array}$ & $\begin{array}{c}8 \\
\text { N. viridescens } \\
\end{array}$ & $\begin{array}{c}8 \\
\text { R. catesbieana } \\
\end{array}$ \\
\hline \multirow{2}{*}{ Enterobacteriaceae } & & $\mathrm{x}$ & $\mathrm{x}$ & $\mathrm{x}$ & & & & $\mathrm{x}$ & $\mathrm{x}$ & $\mathrm{x}$ & \\
\hline & Cedecea & $\mathrm{x}$ & $\mathrm{x}$ & $\mathrm{x}$ & & & $\mathrm{x}$ & & & & $\mathrm{x}$ \\
\hline Microbacteriaceae & Microbacterium & $\mathrm{x}$ & & & $\mathrm{x}$ & $\mathrm{x}$ & $\begin{array}{l}x \\
x\end{array}$ & & & & $x$ \\
\hline \multirow{2}{*}{ Pseudomonadaceae } & & $\mathrm{x}$ & & & $\mathrm{x}$ & & & & & $\mathrm{x}$ & $\mathrm{x}$ \\
\hline & Pseudomonas & $\mathrm{x}$ & $\mathrm{x}$ & $\mathrm{x}$ & & $\mathrm{x}$ & $\mathrm{x}$ & $\mathrm{x}$ & $\mathrm{x}$ & & \\
\hline \multirow{2}{*}{ Sphingobacteriaceae } & & $\mathrm{x}$ & $\mathrm{x}$ & & & & $\mathrm{x}$ & & & & \\
\hline & Pedobacter & $\mathrm{x}$ & & $\mathrm{x}$ & & $\mathrm{x}$ & $\mathrm{x}$ & $\mathrm{x}$ & & & \\
\hline \multirow[t]{2}{*}{ Flavobacteriaceae } & & & & & & $\mathrm{x}$ & $\mathrm{x}$ & $\mathrm{x}$ & & & \\
\hline & Flavobacterium & $\mathrm{x}$ & & & & $\mathrm{x}$ & $\mathrm{x}$ & $\mathrm{x}$ & & & \\
\hline \multirow{3}{*}{ Xanthomonadaceae } & & $\mathrm{x}$ & & & & & $\mathrm{x}$ & & & & \\
\hline & Lysobacter & $\mathrm{x}$ & & & & $\mathrm{x}$ & $\mathrm{x}$ & $\mathrm{x}$ & & & \\
\hline & Stenotrophomonas & $\mathrm{x}$ & & & & & $\mathrm{x}$ & $\mathrm{x}$ & & & \\
\hline \multirow[t]{2}{*}{ Moraxellaceae } & & $\mathrm{x}$ & $\mathrm{x}$ & & & & & & & & \\
\hline & Acinetobacter & $\mathrm{x}$ & & $\mathrm{x}$ & & & & & & & \\
\hline \multirow[t]{2}{*}{ Bacillaceae } & & & & & & & & & & & \\
\hline & Bacillus & $\mathrm{x}$ & & $\mathrm{x}$ & $\mathrm{x}$ & $\mathrm{x}$ & $\mathrm{x}$ & $\mathrm{x}$ & $\mathrm{x}$ & & \\
\hline \multirow[t]{2}{*}{ Comamonadaceae } & & $\mathrm{x}$ & & & & $\mathrm{x}$ & $\mathrm{x}$ & $\mathrm{x}$ & & & \\
\hline & Comamonas & $\mathrm{x}$ & & & & & & & & & \\
\hline \multirow[t]{2}{*}{ Staphylococcaceae } & & & & & & & & & & & $\mathrm{x}$ \\
\hline & Staphylococcus & & $\mathrm{x}$ & & & & & & & & \\
\hline Patulibacteraceae & Patulibacter & & & $\mathrm{x}$ & & & & & & & \\
\hline \multirow[t]{2}{*}{ Oxalobacteraceae } & & & & & $\mathrm{x}$ & $\mathrm{x}$ & $\mathrm{x}$ & & $\mathrm{x}$ & & \\
\hline & Duganella & & & & $\mathrm{x}$ & & $\mathrm{x}$ & & & & \\
\hline Nocardioidaceae & Nocardioides & $\mathrm{x}$ & & & & $\mathrm{x}$ & $\mathrm{x}$ & & & & \\
\hline Brucellaceae & & $\mathrm{x}$ & & & & & & & & & \\
\hline Erythrobacteraceae & & $\mathrm{x}$ & & & & & & & & & \\
\hline Nocardiaceae & & $\mathrm{x}$ & & & & & & & & & \\
\hline Rhizobiales** & & $\mathrm{x}$ & & & & & & & & $\mathrm{x}$ & \\
\hline Cellulomonadaceae & & & & & & & & & & & \\
\hline Outras & & & $\mathrm{x}$ & & & $\mathrm{x}$ & $\mathrm{x}$ & $\mathrm{x}$ & & $\mathrm{x}$ & $\mathrm{x}$ \\
\hline
\end{tabular}

Legenda:1. Presente estudo; 2. Harris et al., 2006; 3. Lauer et al., 2007; 4. Culp et al., 2007; 5.Lauer et al., 2008; 6. Woodhams et al., 2007; 7.Lam et al., 2009; 8. Culp et al., 2007. * Girino; ** Ordem. 
É preciso também considerar que esses experimentos foram realizados utilizandose métodos tradicionais de cultivo e que as bactérias identificadas são facilmente isoladas em meio de cultura R2A. Uma análise molecular, independente de cultivo, poderá complementar essa comparação fornecendo mais informações sobre a especificidade da espécie de anuro e sua comunidade microbiana

Para uma melhor caracterização sobre o perfil microbiano das comunidades dérmicas de anuros identificadas neste trabalho, constam, como segunda parte desta discussão, descrições das famílias identificadas, baseadas em dados obtidos da literatura disponível. A identificação molecular dos isolados revelaram que as comunidades microbianas como sendo compostas por táxons típicos de água e solo, principalmente deste último presença de famílias Gram negativas e positivas, sendo algumas delas produtoras de substâncias proteolíticas, ou seja, capazes de produzir um efeito antibiótico contra outras espécies bacterianas. Podem atuar como patógenos oportunista em plantas e animais. Alguns táxons apresentam o espectro de fontes nutritivas restritas enquanto que outras são genéricas em relação a esse aspecto. As faixas de temperatura de crescimento são bastante amplas e, segundo as descrições disponíveis, varia de 10 a $36^{\circ} \mathrm{C}$. Essas características demonstram que o substrato pele, oferecido pelos anfíbios, pode atender a diversas exigências fisiológicas, constituindo uma complexa interface entre o animal e a microbiota residente de sua pele.

\section{Breves descrições das famílias e gêneros bacterianas identificados}

A família Xanthomonadaceae, do grupo Gammaproteobacteria, é constituída de bactérias Gram negativas e foi identificada para morfotipos isolados apenas de P. boiei. Características descritas para os membros desta família corroboram a nossa idéia inicial de que a comunidade microbiana da pele dos anfíbios é constituída principalmente de entidades do microhabitat ocupado. Por exemplo, no gênero Lysobacter as bactérias são tipicamente 
encontradas no solo, matéria orgânica em decomposição e na água, às vezes em grandes populações. Tem atividade proteolítica contra microrganismos, por meio de enzimas e antibióticos, além de fungos, cianobactérias e nematóide. Alguns isolados apresentam forte atividade antibiótica contra bactérias gram-positivas, especialmente Staphylococcus aureus além de bactérias gram-positivas (Kim et al., 2008; Reichenbach, 2006). Tal atividade antibiótica foi detectada no estudo anterior (Capítulo 2) e a identificação dos morfotipos se encontra no Anexo 1. O Gênero Stenotrophomonas é composto uma única espécie: $S$. maltophila. A temperatura ótima de crescimento é $35^{\circ} \mathrm{C}$ e possui um espectro nutricional restrito. Podem ser isoladas de diversos materiais naturais, infecções humanas e materiais clínicos (Palleroni \& Bradbury et al., 1993). Nosso morfotipo identificado como Stenotrophomonas também apresentou atividade antimicrobiana contra patógenos (Capítulo 2). Membros da família Erythrobacteraceae, pertencente à Classe Alphaproteobacteria, são gram-negativos e têm sido isolados da água doce (Lee et al., 2005).

A família Enterobacteriaceae, presente nas espécies Proceratophrys boiei, Aplastodiscus leucopygius e Phyllomedusa distincta retrata outro componente da microbiota cutânea desses anuros, o componente entérico. Esta família é composta de representantes gram-negativos, com temperatura de crescimento na faixa de 22 a $35^{\circ} \mathrm{C}$ e tem ampla distribuição geográfica e grande heterogeneidade em sua ecologia, hospedeiros e patogenicidade para o Homem, animais e plantas (Ewing et al., 1980, Garrity et al., 2005). Gênero Cedecea é constituído principalmente de patógenos oportunistas que crescem bem nas temperaturas 15,20 e $37^{\circ} \mathrm{C}$ em pH 7. Podem também colonizar as superfícies dos corpos humanos e ainda ser isolados de corpos de água, carrapatos e insetos (Garrity et al., 2005; Grimont et al., 1981). Outras famílias típicas de ambiente são: 
Família Microbacteriaceae que pertence à classe Actinobacteria são bactérias gram-positivas estão presentes em vários ecossistemas terrestres e aquáticos e podem estar associados clinicamente com plantas, fungos, animais. O gênero Microbacterium apresenta resistência ao aquecimento e produção de ácido lático a partir de glicose (Evtushenko \& Takeuchi, 2006). A família Sphingobacteriaceae é composta por bactérias Gram negativas com crescimento ótimo em faixa de temperatura que vai de 0 a $30^{\circ} \mathrm{C}$. Os membros dessa família são comumente isolados do solo, lodo ativado, peixes e de espécimes clínicos. Não há espécies consideradas como patógenos verdadeiros. O gênero Pedobacter é composto por uma maioria de espécies produtoras de heparinase, aeróbias obrigatórias e bacilos Gramnegativos. (Steyn et al., 1998; (Gallego et al., 2006). A família Cellulomonadaceae, identificada para bactéria residente na pele de A. leucipygius, pertence à ordem Actinomycetales e compreende dois gêneros: Cellulomonas e Oerskovia. No primeiro gênero o principal habitat é o solo e apresentam atividade celulolítica. Representantes do gênero Oerskoviae foram isolados de vários tipos de solo e regiões geográficas, bem como de amostras clínicas. Produzem ácidos a partir de diversos carboidratos (Stackebrandt, 2006). Patulibacteriaceae encontrada apenas em $P$. distincta, é uma nova família de bactérias Gram positivas, pertencente à classe Actinobacteria e à ordem Rubrobacterales. Isoladas de solo. $\mathrm{O}$ gênero Patulibacter é composto de bactérias aeróbias, parede celular com peptídeoglicanos (Tkahashi et al., 2006). Oxalobacteraceae é uma família nova constituída por representantes típicos de solos (Green et al., 2007).

Nocardiaceae bactérias gram-positivas e formam substratos com hifas, sendo amplamente distribuídos nos ambientes aquáticos e terrestres. Alguns são oportunísticamente patógenos para animais, inclusive humanos. Alguns representantes são comuns em solo e parecerem estar envolvidos com ciclagem de matéria orgânica (Goodfellow \& Maldonado, 
2006). Neste estudo foram identificados dois morfotipos, apenas de bactérias isoladas de $P$. boiei, que por estar associado ao folhiço, deve ter obtido cepas de tal substrato, que passaram a constituir sua microbiota.

A família Pseudomonadaceae, presente nas quatro espécies estudadas, é composta por bactérias Gram negativas intolerantes a pH ácido, 4.5 ou abaixo (a maioria) e crescem bem mesmo na ausência de fatores orgânicos complexos. São amplamente distribuídas na natureza e algumas espécies são patógenos para animais, incluindo o Homem, ou plantas. Em geral, animais não são boas fontes de espécies de Pseudomonas, a menos que estejam evolvidos em infecções como patógenos oportunistas, porém no caso dos anfíbios é possível detectar representantes desse gênero como constituintes da microbiota residente desses animais, como observado no presente estudo e em estudos anteriores (Harris et al., 2006; Lauer et al., 2007; Culp et al., 2007; Lauer et al., 2008; Woodhams et al., 2007; Lam et al., 2009). São muito resistentes ao stress ambiental, característica atribuída à capacidade de mudanças no material genético mediante a mudanças no ambiente. Além de apresentarem resistência a antibióticos (Garrity et al., 2005), isolados identificados como Pseudomonas neste estudo, apresentaram poder inibitório do crescimento de patógenos em nosso estudo anterior (Capítulo 2).

Na família Flavobacteriaceae as bactérias são Gram-negativas e o ótimo de temperatura varia de 25 a $35^{\circ} \mathrm{C}$ (Bernardet at al., 2002). Apesar de possuir ampla faixa de ambientes (característica marcante dessa família): solo, ambientes de água doce, ambientes marinhos, doenças em gatos, cachorros, anfíbios e répteis, doenças de peixes marinhos e dulcícolas, doenças em moluscos, crustáceos, pássaros, doenças de plantas, simbiontes intracelulares de insetos, neste estudo esteve presente apenas em P. boiei. Algumas enzimas com atividade proteolíticas são sintetizadas por flavobacterias em diversos ambientes, bem 
como a pele de $P$. boiei, pois o potencial antimicrobiano do isolado Flavobacterium se confirmou em nosso estudo anterior (Capítulo 2). Nesse gênero os organismos são amplamente distribuídos no solo e água doce, onde eles decompõem matéria orgânica (Bernardet et al., 1996). Em muitos casos de doenças, flavobacterias atuam oportunísticamente, infeccionando hospedeiros que estão previamente imunologicamente comprometidos individualmente ou por resultado de perturbações no ambiente (Bernardet \& Bowman, 2006).

Os organismos pertencentes à família Comamonadaceae são genotipicamente muito relacionados e fenotipicamente muito diversos. São Gram negativos e a faixa de temperatura ótima entre 28 e $30^{\circ} \mathrm{C}$. Estão presentes no solo e água, podem ser patógenos de plantas (Willems et al., 1991; De Vos et al., 1985). Foi identificada apenas para dois morfotipos isolados de $P$. boiei.

A família Moraxellaceae, presente nas espécies de anuros Proceratophrys boiei, Aplastodiscus leucopygius e Phyllomedusa distincta, pertence ao grupo Gammaproteobacteria e consiste de bactérias Gram negativas, com temperatura ótima de crescimento de 14 a $36{ }^{\circ} \mathrm{C}$. Algumas espécies requerem complexos fatores para o crescimento, enquanto outras crescem em meio com uma única fonte de carbono e fonte de energia. Podem ser isolados do solo, água, alimentos, pele e mucosas de animais, inclusive humanos (Garrity et al., 2005). Representantes do gênero Acinetobacter, identificado de isolado de bactéria de $P$. boiei, podem ser encontrados no solo, onde podem degradar matéria orgânica, água e esgotos. Como patógenos, membros desse gênero são descritos como oportunistas, causando um amplo espectro de infecções hospitalares (Towner, 2006).

Na família Bacillaceae, não presente apenas em A. leucopygius, o gênero Bacillus apresenta grande diversidade de fisiologia, ecologia e genética. Apresenta produção de 
esporos de resistência química e física. Degradam grande parte dos substratos derivados de plantas e animais; são produtores de antibióticos como metabólitos secundários eficazes contra bactérias Gram positivas, e de enzimas bacteriolíticas. Devido à formação de esporos, podem persistir em diversos ambientes estressantes (Slepecky \& Hemphill, 2006).

No gênero Staphylococcus da família Staphylococcaceae as bactérias são Gram positivas e muitas espécies são importantes patógenos, como Staphylococcus aureus, um patógeno oportunista que causa grandes taxas de mortalidade. Podem ser isolados da pele e membranas mucosas (Götz et al., 2006), no presente estudo, foi identificado apenas para morfotipo bacteriano de A. leucopygius. A família Brucellaceae também é composta de alguns patógenos que causam infecção, penetrando a pele de outros organismos, através de membranas mucosas, em animais endotérmicos e, mais raramente, em ectotérmicos (Breed et al., 1957). 
Anexo 1 
Tabela 1. Identificação dos isolados da espécie Proceratophrys boiei.

\begin{tabular}{|c|c|c|c|c|c|}
\hline \multirow[t]{2}{*}{$\begin{array}{l}\text { Isolado } \\
\text { bacteriano }\end{array}$} & \multirow[t]{2}{*}{ pb } & \multirow[t]{2}{*}{ Sequências Tipo mais próximas } & \multirow[t]{2}{*}{ Simil. } & \multicolumn{2}{|c|}{ Classificação } \\
\hline & & & & Família: & Gênero \\
\hline \multirow[t]{2}{*}{ RG28-61 } & 157 & Luteimonas aestuarii B9; EF660758 & 0.954 & Xanthomonadaceae & \\
\hline & & Xanthomonas codiaei LMG 8678 T; Y1076 & 0.954 & & \\
\hline \multirow[t]{2}{*}{ NSV95-169 } & 132 & Brucella melitensis 2000031283; ATCC 23456; & 1.000 & Brucellaceae & \\
\hline & & Mycoplana ramosa IAM 13949; D13944 & 1.000 & & \\
\hline \multirow[t]{2}{*}{ RG31-96 } & 157 & Kluyvera cryocrescens ATCC33435; AF310218 & 1.000 & Enterobacteriaceae & \\
\hline & & Buttiauxella ferragutiae DSM 9390; AJ233402 & 0.940 & & \\
\hline \multirow[t]{2}{*}{ RG28-58 } & 132 & Altererythrobacter epoxidivorans JCS350; DQ304436 & 1.000 & Erythrobacteraceae & \\
\hline & & Erythrobacter flavus SW-46; AF500004 & 1.000 & & \\
\hline \multirow[t]{2}{*}{ SLP2-2 } & 137 & Clavibacter michiganensis DSM 7483; X77434 & 0.969 & Microbacteriaceae & \\
\hline & & Curtobacterium luteum DSM 20542; X77437 & 0.969 & & \\
\hline \multirow[t]{2}{*}{ NSV95-168M2B } & 138 & Clavibacter michiganensis DSM 7483; X77434 & 0.962 & Microbacteriaceae & \\
\hline & & Frigoribacterium mesophilum MSL 08; EF466126 & 0.962 & & \\
\hline \multirow[t]{2}{*}{ SLP125-206 } & 139 & Rhodococcus qingshengii dj1-6; DQ090961 & 0.977 & Nocardiaceae & \\
\hline & & Rhodococcus erythropolis X79289 & 0.977 & & \\
\hline \multirow[t]{2}{*}{ SLP128-212 } & 158 & Pseudomonas graminis DSM 11363; Y11150 & 0.945 & Pseudomonadaceae & \\
\hline & & Pseudomonas japonica IAM 15071; AB126621 & 0.945 & & \\
\hline \multirow[t]{2}{*}{ SLP2-1 } & 152 & Olivibacter ginsengisoli Gsoil 060; AB267716 & 0.731 & Sphingobacteriaceae & \\
\hline & & Pedobacter terricola DS-45; EF446147 & 0.752 & & \\
\hline \multirow[t]{2}{*}{ SLP2-4 } & 137 & Microbacterium arborescens DSM 20754; X77443 & 1.000 & Microbacteriaceae & Microbacterium \\
\hline & & Microbacterium hominis DSM 12509; AM181504 & 1.000 & & \\
\hline \multirow[t]{2}{*}{ SLP124-196 } & 153 & Flavobacterium soli DS-6; DQ178976 & 0.874 & Flavobacteriaceae & Flavobacterium \\
\hline & & Flavobacterium anhuiense D3; EU046269 & 0.853 & & \\
\hline \multirow[t]{2}{*}{ RG57-130 } & 146 & Pedobacter soli $(\mathrm{T}):$ 15-51; AM279215 & 1.000 & Sphingobacteriaceae & Pedobacter \\
\hline & & Pedobacter wanjuense (T): GH09-10; AM279217 & 1.000 & & \\
\hline \multirow[t]{2}{*}{ SLP3-16 } & 151 & uncultured bacterium; ASP-7; EF679183 & 1.000 & Comamonadaceae & \\
\hline & & uncultured Comamonas sp.; LSS-E5; FJ946520 & 1.000 & & \\
\hline \multirow[t]{2}{*}{ RG30-87 } & 150 & uncultured bacterium; BPH2027; DQ221467 & 0.953 & Enterobacteriaceae & \\
\hline & & Erwinia sp. Z2NS-96; FJ784638 & 0.953 & & \\
\hline \multirow[t]{2}{*}{ RG28-51 } & 150 & Enterobacter sp. VET-37; EU781736 & 0.953 & Enterobacteriaceae & \\
\hline & & uncultured bacterium; BPH1C4002; DQ221276 & 0.953 & & \\
\hline RG31-95 & 151 & Pseudomonas graminis; HhSaOsb; AF511514 & 1.000 & Pseudomonadaceae & Pseudomonas \\
\hline
\end{tabular}




\section{RG58-132}

\section{SLP124-195}

\section{SLP128-213}

RG30-88

INT40-109M1

NSV95-161

NSV95-168M2A

NSV95-170

NSV95-162

RG30-89

INT35-103

INT35-105

INT35-106

INT35-107

NSV95-163

SLP124-197

INT40-102M2
Pseudomonas putida; YTK10; AB079094

151 Lysobacter sp. C3; AY074793

Lysobacter enzymogenes; YC013; EU430118

151 Acinetobacter sp.; DSM 590; X81659

uncultured gamma proteobacterium; 1026; EF188481

151 Stenotrophomonas sp. RBE2CD-33; EF111221

Pantoea dispersa (T); LMG2603; DQ504305

131 Nocardioides furvisabuli (T); SBS-26; DQ411542 Nocardioides terrigena (T); DS-17; EF363712

151 Pseudomonas cedrina (T); type strain: DSM 14938 Pseudomonas fulva (T); AJ 2129; AB046996

151 Bacillus mycoides (T); ATCC6462; AB021192 Bacillus weihenstephanensis (T); DSM11821; AB021199

148 Comamonas testosteroni (T); M11224 Comamonas kerstersii (T); type strain: LMG 3475

151 Bacillus mycoides (T); ATCC6462; AB021192 Bacillus weihenstephanensis (T); DSM11821; AB021199

131 Clavibacter michiganensis (T); LMG 3663 (Type); U09761 Leifsonia aquatica (T); JCM 1368; D45057

125 Devosia riboflavina (T); type strain: DSM 7230; AJ549086 Rhizobium larrymoorei (T); 3-10; Z30542

144 Flexibacter aurantiacus (T); M62792 Flavobacterium johnsoniae (T); type strain: DSM 2064

144 Flexibacter aurantiacus (T); M62792 Flavobacterium johnsoniae (T); type strain: DSM 2064

144 Flexibacter aurantiacus (T); M62792 Flavobacterium johnsoniae (T); type strain: DSM 2064

151 Azotobacter beijerinckii (T); ICMP 8673; ATCC 19360 Azotobacter chroococcum (T); IAM 12666; AB175653

150 Kluyvera cryocrescens (T); ATCC33435; AF310218 Raoultella ornithinolytica (T); CIP 103364 T; U78182

151 Acinetobacter lwoffii (T); DSM 2403; X81665 Acinetobacter johnsonii (T); ATCC 17909T

151 Stenotrophomonas terrae (T); type strain: R-32768 Stenotrophomonas koreensis (T); TR6-01; AB166885
1.000

1.000

1.000

1.000

1.000

1.000

0.956

1.000

0.954

1.000

1.000

1.000

1.000

0.912

0.824

1.000

1.000

1.000

1.000

1.000

1.000

1.000

0.965

1.000

0.965

1.000

0.965

0.947

0.934

1.000 Enterobacteriaceae

1.000

0.934

0.861

0.881 Xanthomonadaceae

Moraxellaceae

Xanthomonadaceae

Nocardioidaceae

Pseudomonadaceae

Bacillaceae

Comamonadaceae

Bacillaceae

Microbacteriaceae

Rhizobiales

Flavobacteriaceae

Flavobacteriaceae

Flavobacteriaceae

Pseudomonadaceae

Moraxellaceae
Xanthomonadaceae Lysobacter

0.887
Acinetobacter

Stenotrophomonas

Nocardioides

Bacillus

Comamonas

Bacillus

\section{Flavobacterium}

Flavobacterium

Flavobacterium Abreviações: pb número de pares de bases nitrogenadas; Simil., similaridade; (T), amostra tipo.Obs.: Os isolados em negrito apresetaram poder
inibitório nos ensaios de cross-streak. 
Tabela 2. Identificação dos isolados da espécie Aplastodiscus leucopygius.

\begin{tabular}{|c|c|c|c|c|c|}
\hline $\begin{array}{l}\text { Isolado } \\
\text { bacteriano } \\
\end{array}$ & pb & Sequências Tipo mais próximas & Simil. & Classificação & \\
\hline & & & & Família: & Gênero \\
\hline \multirow[t]{2}{*}{ SLP16-26 } & 157 & Enterobacter asburiae (T); JCM6051; AB004744 & 1.000 & Enterobacteriaceae & \\
\hline & & Pantoea agglomerans (T); DSM 3493; AJ233423 & 0.960 & & \\
\hline \multirow[t]{2}{*}{ SLP17-29 } & 157 & Pseudomonas parafulva (T); IAM 1541; AB046999 & 0.954 & Pseudomonadaceae & Pseudomonas \\
\hline & & Pseudomonas cremoricolorata (T); IAM $1541 \mathrm{~T}$ & 0.954 & & \\
\hline \multirow[t]{2}{*}{ SLP97-171 } & 157 & Staphylococcus equorum (T); RP29; AF527483 & 0.973 & Staphylococcaceae & Staphylococcus \\
\hline & & Staphylococcus equorum (T); ATCC 43958T & 0.973 & & \\
\hline \multirow[t]{2}{*}{ SLP97-172 } & 158 & Acinetobacter calcoaceticus (T); type strain: NCCB 22016 & 1.000 & Moraxellaceae & \\
\hline & & Acinetobacter baumannii (T); DSM 30007; X81660 & 0.921 & & \\
\hline \multirow[t]{2}{*}{ NSV92-173 } & 152 & Pedobacter roseus (T); CL-GP80; DQ112353 & 0.952 & Sphingobacteriaceae & \\
\hline & & Pedobacter borealis (T); G-1; EU030687 & 0.863 & & \\
\hline \multirow[t]{2}{*}{ NSV98-174 } & 138 & Kocuria palustris (T); TAGA27 (DSM 11925, type strain) & 1.000 & Cellulomonadaceae & \\
\hline & & Kocuria turfanensis (T); HO-9042; DQ531634 & 0.969 & & \\
\hline \multirow[t]{2}{*}{ SLP17-27 } & 157 & Enterobacter cowanii (T); type strain: CIP 107300 & 0.953 & Enterobacteriaceae & \\
\hline & & Escherichia vulneris (T); ATCC 33821; AF530476 & 0.913 & & \\
\hline \multirow[t]{2}{*}{ SLP17-28 } & 157 & Shigella flexneri $(\mathrm{T}) ; \mathrm{X} 96963$ & 1.000 & Enterobacteriaceae & \\
\hline & & Escherichia albertii (T); type strain: LMG 20976; AJ508775 & 1.000 & & \\
\hline \multirow[t]{2}{*}{ NSV99-175 } & 129 & Agrococcus lahaulensis (T); K22-21; DQ156908 & 0.922 & Microbacteriaceae & \\
\hline & & Microbacterium aurum (T); DSM 8600; Y17229 & 0.922 & & \\
\hline \multirow[t]{2}{*}{ NSV99-176 } & 151 & Pseudomonas chlororaphis (T); DSM 50083T (type strain) & 1.000 & Pseudomonadaceae & Pseudomonas \\
\hline & & Pseudomonas chlororaphis (T); DSM 6698; AY509898 & 1.000 & & \\
\hline \multirow[t]{2}{*}{ NSV99-177 } & 151 & Pseudomonas chlororaphis (T); DSM 50083T (type strain) & 1.000 & Pseudomonadaceae & Pseudomonas \\
\hline & & Pseudomonas chlororaphis (T); DSM 6698; AY509898 & 1.000 & & \\
\hline
\end{tabular}

Abreviações: pb número de pares de bases nitrogenadas; Simil., similaridade; (T), amostra tipo.

Obs.: Os isolados em negrito apresetaram poder inibitório nos ensaios de cross-streak. 
Tabela 3. Identificação dos isolados da espécie Phyllomedusa distincta.

\begin{tabular}{|c|c|c|c|c|c|}
\hline \multirow{2}{*}{\multicolumn{3}{|c|}{ 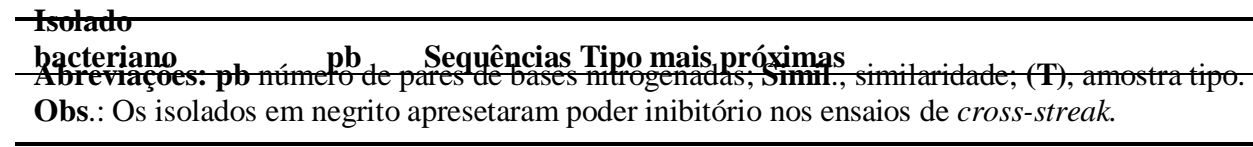 }} & \multirow{2}{*}{ Simil. } & \multicolumn{2}{|l|}{ Classificação } \\
\hline & & & & Família: & \multirow[t]{2}{*}{ Gênero } \\
\hline \multirow[t]{2}{*}{ INT27-42 } & 157 & Enterobacter hormaechei (T); CIP 103441; AJ508302 & 0.967 & Enterobacteriaceae & \\
\hline & & Salmonella enterica (T); DSM 9221; EU014684 & 0.913 & & \\
\hline \multirow[t]{2}{*}{ INT26-41 } & 157 & Pseudomonas cedrina (T); type strain: DSM 14938 & 1.000 & Pseudomonadaceae & Pseudomonas \\
\hline & & Pseudomonas fulva (T); AJ 2129; AB046996 & 1.000 & & \\
\hline \multirow[t]{2}{*}{ RG53-112 } & 151 & Bacillus mycoides (T); ATCC6462; АB021192 & 1.000 & Bacillaceae & Bacillus \\
\hline & & Bacillus cereus (T); ATCC 14579; AE016877 & 1.000 & & \\
\hline \multirow[t]{2}{*}{ RG55-116 } & 149 & Patulibacter minatonensis (T); KV-614; AB193261 & 0.886 & Patulibacteraceae & Patulibacter \\
\hline & & uncultured Patulibacter sp.; A09-10F; FJ542906 & 0.886 & & \\
\hline \multirow[t]{2}{*}{ RG55-117 } & 130 & Clavibacter michiganensis; PD039; AF474328 & 1.000 & Microbacteriaceae & \\
\hline & & Curtobacterium luteum (T); DSM 20542; X77437 & 1.000 & & \\
\hline \multirow[t]{2}{*}{ RG55-118 } & 151 & Endosymbiont of Metaseiulus occidentalis; pAJ240 & 0.993 & Enterobacteriaceae & \\
\hline & & Escherichia coli; RGR13; DQ118017 & 0.993 & & \\
\hline \multirow[t]{2}{*}{ INT68-141 } & 151 & Enterobacter sp. HPC64; AY996978 & 0.993 & Enterobacteriaceae & \\
\hline & & bacterium C20; DQ329338 & 0.993 & & \\
\hline \multirow[t]{2}{*}{ INT68-143 } & 151 & Endosymbiont of Metaseiulus occidentalis; pAJ240 & 0.960 & Enterobacteriaceae & \\
\hline & & Escherichia coli; RGR13; DQ118017 & 0.960 & & \\
\hline \multirow[t]{2}{*}{ INT69-145 } & 150 & uncultured bacterium; hl10b7; DQ279606 & 1.000 & Enterobacteriaceae & Cedecea \\
\hline & & Enterobacter sp. HPC64; AY996978 & 1.000 & & \\
\hline \multirow[t]{2}{*}{ INT20-33 } & 151 & Pseudomonas sp.; LY3; AJ007006 & 1.000 & Pseudomonadaceae & Pseudomonas \\
\hline & & Arthrobacter sp. LF-Tou2; AY641537 & 1.000 & & \\
\hline \multirow[t]{2}{*}{ RG66-140 } & 151 & Acinetobacter sp. RUH53T; RUH53T (Aci 694) & 1.000 & Moraxellaceae & Acinetobacter \\
\hline & & Acinetobacter calcoaceticus; TS2H; EF151807 & 1.000 & & \\
\hline \multirow[t]{2}{*}{ INT19-30 } & 155 & Tatumella ptyseos (T); DSM 5000; AJ233437 & 0.865 & Enterobacteriaceae & \\
\hline & & Xenorhabdus koppenhoeferi (T); USNJ01 & 0.858 & & \\
\hline \multirow[t]{2}{*}{ RG53-111M1 } & 146 & Pedobacter roseus (T); CL-GP80; DQ112353 & 0.952 & Sphingobacteriaceae & Pedobacter \\
\hline & & Pedobacter terrae (T); DS-57; DQ889723 & 0.863 & & \\
\hline \multirow[t]{2}{*}{ RG61-134 } & 150 & Pantoea agglomerans (T); DSM 3493; AJ233423 & 0.933 & Enterobacteriaceae & \\
\hline & & Escherichia vulneris (T); ATCC 33821; AF530476 & 0.960 & & \\
\hline \multirow[t]{2}{*}{ INT23-37 } & 1074 & Serratia nematodiphila (T); DZ0503SBS1; EU036987 & 0.992 & Enterobacteriaceae & \\
\hline & & Serratia marcescens (T); KRED; AB061685 & 0.988 & & \\
\hline
\end{tabular}


Tabela 4. Identificação dos isolados da espécie Dendropsophus minutus.

\begin{tabular}{|c|c|c|c|c|c|}
\hline $\begin{array}{l}\text { Isolado } \\
\text { bacteriano }\end{array}$ & pb & Sequências Tipo mais próximas & Simil. & Classificação & \\
\hline & & & & Família: & Gênero \\
\hline \multirow[t]{2}{*}{ RG102-186 } & 151 & Bacillus mycoides (T); ATCC6462; AB021192 & 1.000 & Bacillaceae & Bacillus \\
\hline & & Bacillus weihenstephanensis (T); DSM11821 & 1.000 & & \\
\hline \multirow{2}{*}{ NSV91-160 } & 151 & Bacillus mycoides (T); ATCC6462; АB021192 & 1.000 & Bacillaceae & Bacillus \\
\hline & & Bacillus weihenstephanensis (T); DSM11821 & 1.000 & & \\
\hline \multirow[t]{2}{*}{ RG102-186 } & 152 & Bacillus weihenstephanensis (T); DSM11821 & 0.993 & Bacillaceae & Bacillus \\
\hline & & Bacillus mycoides (T); ATCC6462; АB021192 & 0.993 & & \\
\hline \multirow[t]{2}{*}{ INT74-152 } & 151 & Bacillus thuringiensis; WS 261; Z84584 & 1.000 & Bacillaceae & Bacillus \\
\hline & & Bacillus mycoides; MWS5303-1-4; Z84582 & 1.000 & & \\
\hline \multirow[t]{2}{*}{ INT76-157 } & 149 & uncultured bacterium; Hel3ad07; FJ229296 & 1.000 & Oxalobacteraceae & Duganella \\
\hline & & uncultured bacterium; N2_S4C03f; AB485545 & 0.966 & & \\
\hline \multirow[t]{2}{*}{ RG101-180 } & 130 & Microbacterium laevaniformans; АB007416 & 1.000 & Microbacteriaceae & Microbacterium \\
\hline & & Microbacterium imperiale; $27 \mathrm{v} 1 \mathrm{~b} ;$ AF526916 & 1.000 & & \\
\hline \multirow[t]{2}{*}{ RG102-184 } & 151 & Pseudomonas filiscindens; ATCC BAA-697 & 1.000 & Pseudomonadaceae & \\
\hline & & P. chlororaphis subsp. aurantiaca; ATCC 33663T & 1.000 & & \\
\hline \multirow[t]{2}{*}{ INT73-150 } & 151 & Bacillus mycoides (T); ATCC6462; АB021192 & 1.000 & Bacillaceae & Bacillus \\
\hline & & Bacillus cereus (T); ATCC 14579; AE016877 & 1.000 & & \\
\hline \multirow[t]{2}{*}{ INT75-155M1 } & 151 & Bacillus mycoides (T); ATCC6462; АВ021192 & 1.000 & Bacillaceae & Bacillus \\
\hline & & Bacillus anthracis (T); ATCC 14578; AB190217 & 1.000 & & \\
\hline \multirow[t]{2}{*}{ INT75-155M2 } & 150 & Massilia timonae (T); timone; U54470 & 0.900 & Oxalobacteraceae & \\
\hline & & Massilia aerilata $(\mathrm{T}) ; 5516 \mathrm{~S}-11 ; \mathrm{EF} 688526$ & 0.907 & & \\
\hline
\end{tabular}

Abreviações: pb número de pares de bases nitrogenadas; Simil., similaridade; (T), amostra tipo.

Obs.: Os isolados em negrito apresetaram poder inibitório nos ensaios de cross-streak. 
Anexo 2 


\section{FILO PROTEOBACTERIA}

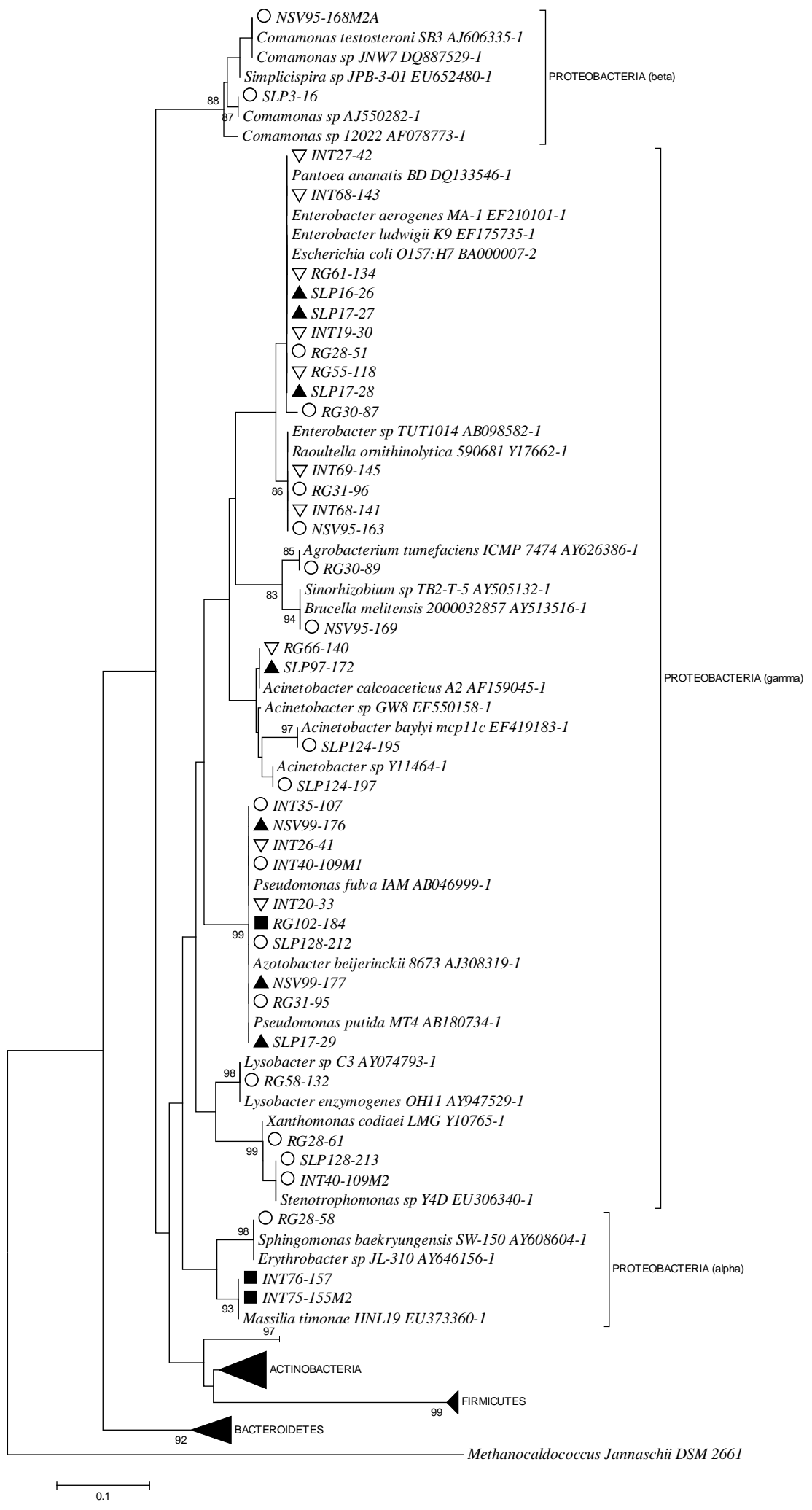

Figura 1. Árvore filogenética baseada em sequiências do gene 16S rRNA de morfotipos isolados de colônias bacterianas pertencentes a Proteobacteria, junto com seqüências similares e representativas do banco de dados do NCBI e RDP. Gerada utilizando o método Neighbor joining com análise de bootstraping com 1000 repetições. Quadrado representa a espécie Dendropsophus minutus; círculo, Proceratophrys boiei; triângulo, Aplastodiscus leucopygius e triângulo invertido, Phyllomedusa distincta. 


\section{FILO: ACTINOBACTERIA}

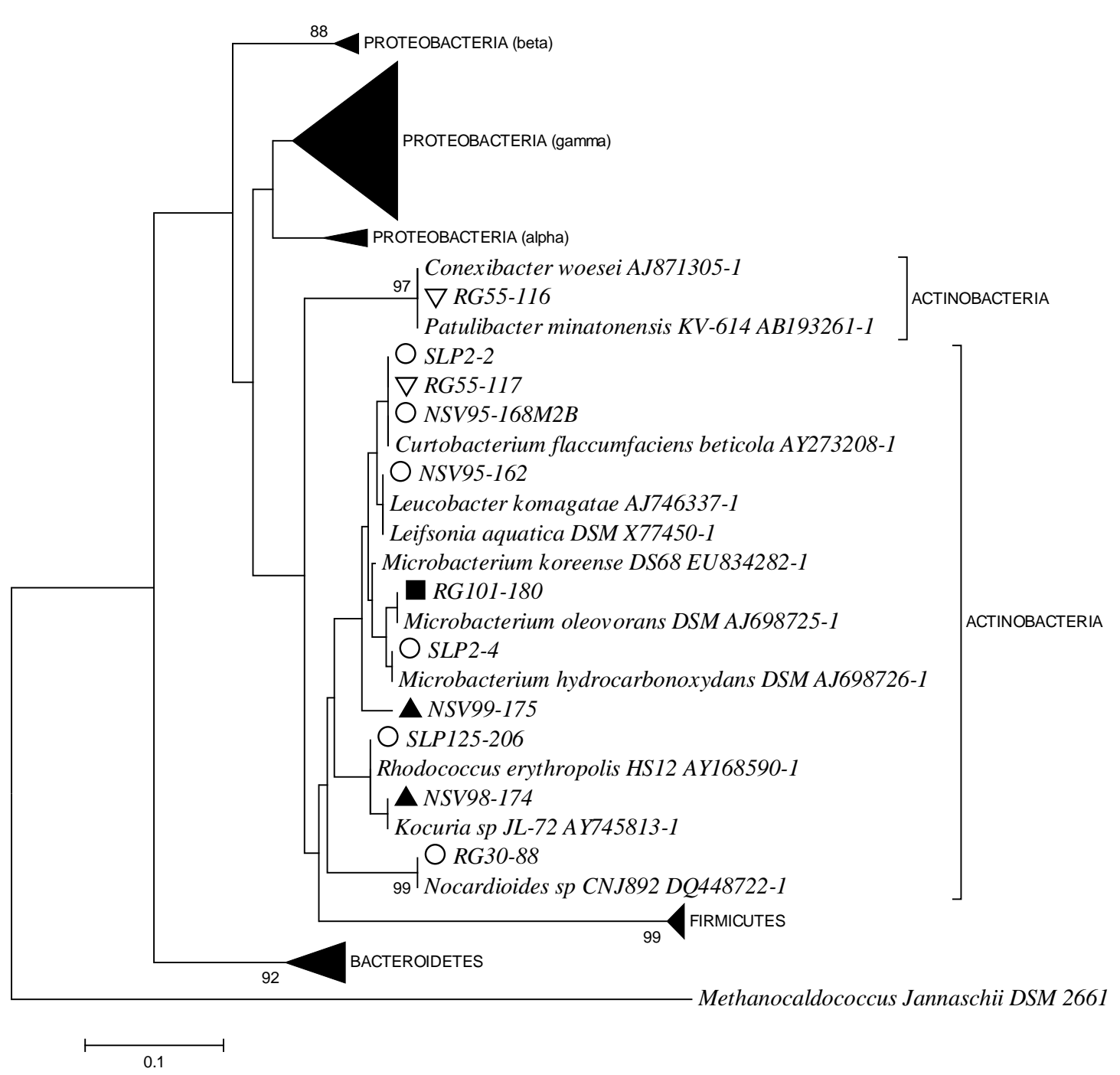

Figura 2. Árvore filogenética baseada em seqüências do gene 16S rRNA de morfotipos isolados de colônias bacterianas pertencentes a Actinobacteria, junto com seqüências similares e representativas do banco de dados do NCBI e RDP. Gerada utilizando o método Neighbor joining com análise de bootstraping com 1000 repetições. Quadrado representa a espécie Dendropsophus minutus; círculo, Proceratophrys boiei; triângulo, Aplastodiscus leucopygius e triângulo invertido, Phyllomedusa distincta. 


\section{FILO FIRMICTES}

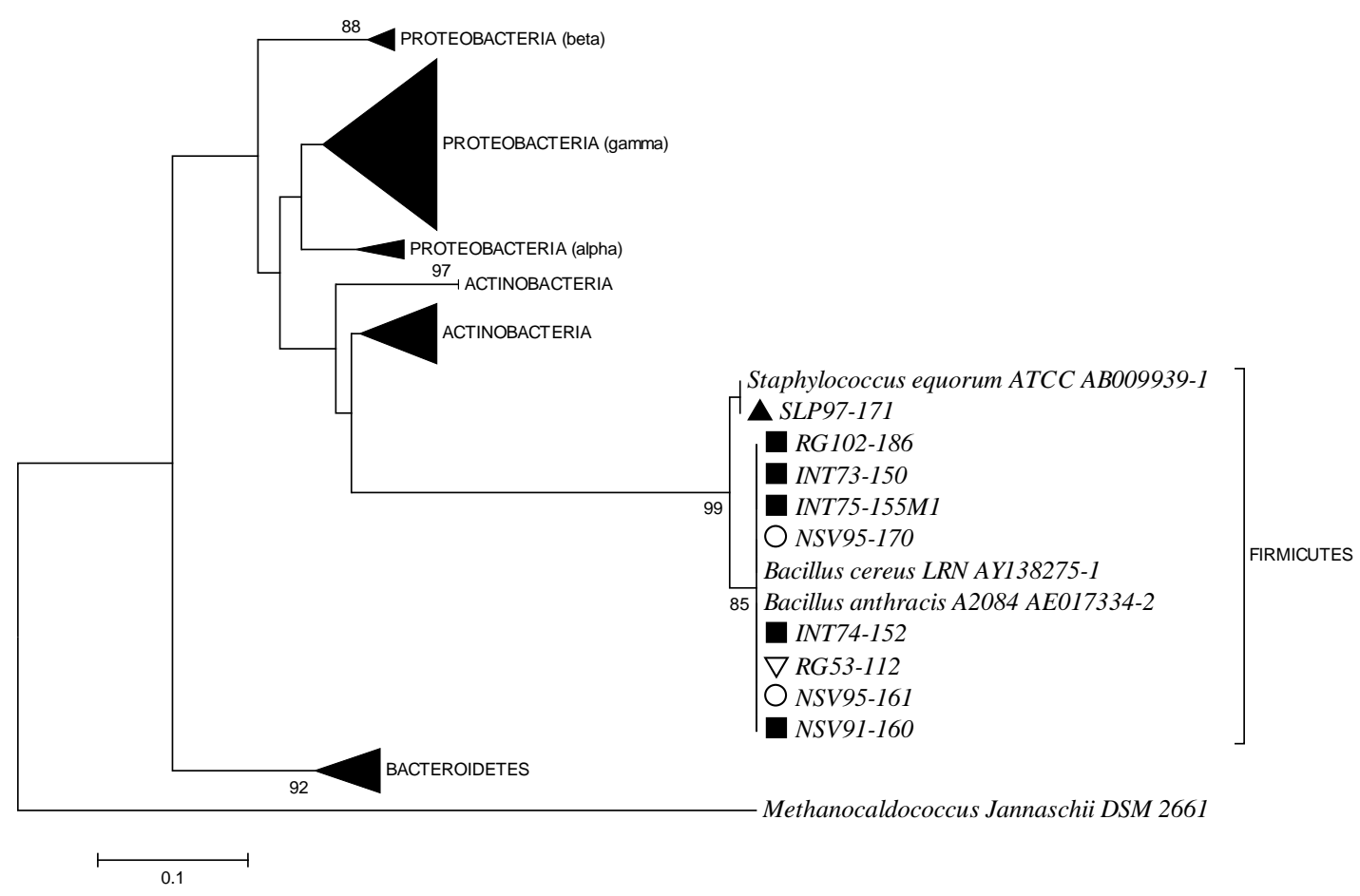

Figura 3. A rvore filogenética baseada em seqüências do gene 165 rR NA de morfotipos isolados de colônias bacterianas pertencentes a Firmicutes, junto com seqüências similares e representativas do banco de dados do NCBI e RDP. Gerada utilizando o método Néghbor jaining com análise de boostraping com 1000 repetições. Quadrado representa a espécie Dendropsophus minutus círculo, Proceratophrys boie; triângulo, Aplastodisaus leucopygius e triângulo invertido, Phyllomedusa distincta 


\section{FILO BACTEROIDETES}

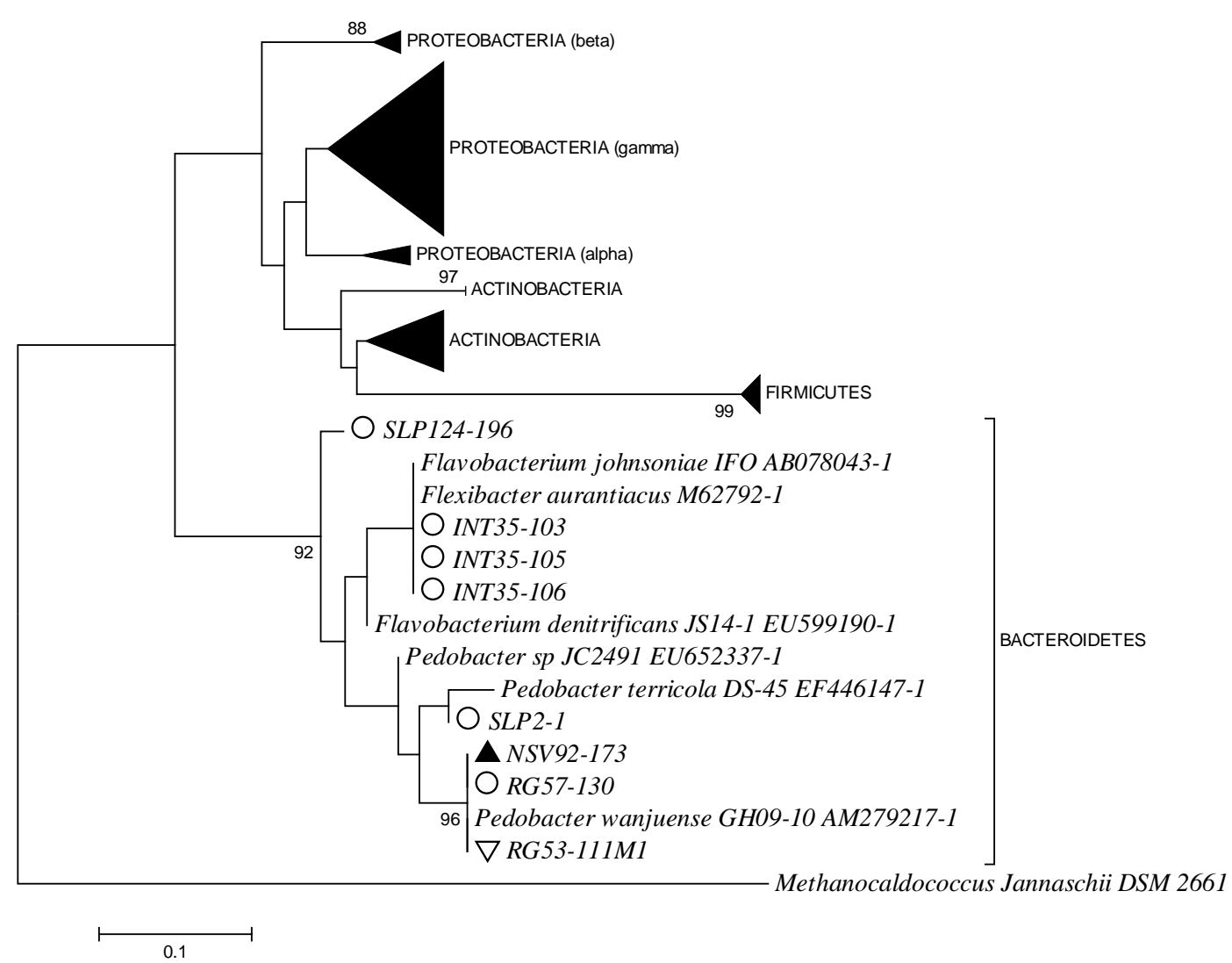

Figura 4. Arvore filogenética baseada em seqüências do gene $16 \mathrm{~S}$ rRNA de morfotipos isolados de colônias bacterianas pertencentes a Bacterioidetes, junto com seqüências similares e representativas do banco de dados do NCBI e RDP. Gerada utilizando o método Nejghbor jaining com análise de bootstraping com 1000 repetições. Quadrado representa a espécie Dendropsophus minutus círculo, Proceratophrys baie; triângulo, Aplastodi sausleucopygiuse triângulo invertido, Phyllomedusa distinda. 


\section{Discussão Geral e Conclusões}

Através de nossa pesquisa foi possível detectar algumas características das comunidades microbianas residente na pele das espécies de anuros estudadas: Dendropsophus minutus, Proceratophrys boiei, Aplastodiscus leucopygius e Phyllomedusa. A primeira delas é as diferenças de densidades e riquezas microbianas entre as espécies de anuros. Apesar de ainda não entendermos as implicações ecológicas dessas diferenças, é possível que hajam padrões de comunidades relacionados aos grupos taxonômicos, que podem ser determinados pelas características do ambiente, pelos atributos da história de vida e pela fisiologia inerente a cada grupo. Um primeiro indicativo do papel da paisagem na composição das microbiotas cutâneas foi o achado de uma maior densidade nos remanescentes, quando comparados às áreas contínuas, assim como de uma maior riqueza de morfotipos. Assim como as diferenças encontradas quando feita a análise das espécies, considerando os microhabitats ocupados. A presença de famílias e gêneros bacterianos típicos de ambiente corrobora a nossa hipótese central da influência do ambiente sobre as comunidades da pele. Assim como o impacto sobre essas comunidades como conseqüência de alterações no ambiente feitas pelo homem.

A presença de bactérias com propriedades antimicrobianas contra patógenos, ressalta a importância dessas comunidades como primeira barreira protetora, pois ainda não há motivos para acreditarmos que os efeitos verificados in vitro não ocorram no meio natural. Considerando isso, então novamente o ambiente atuaria como um mediador da susceptibilidade dos anfíbios aos patógenos, pois alterações nessas comunidades também afetariam as populações bacterianas com esse potencial antimicrobiano. Um estudo 
complementar e mais conclusivo será feito com base nas análises da microbiota dos microhabitas ocupados em comparação à microbiota cutânea dos anfíbios.

A ocorrência de famílias e gêneros bacterianos que foram identificados em outros táxons de anfíbios, inclusive em outra ordem (Urodela), e em outra região geográfica (América do Norte), pode ter relação com processos de seleção dessas bactérias por características inerentes às espécies de anfíbios. Esse achado pode servir como plataforma para estudos de distribuição de microbiana, processos de co-evolução patógeno-hospedeiro e influencia da microbiota nas doenças emergentes de anuros. 


\section{Resumo Geral}

A pele dos anfíbios, assim como de outros animais, atua como primeira proteção contra agentes patogênicos. A comunidade microbiológica ali residente é composta de algumas espécies de bactérias, e estas, possuem ação antifúngica contra patógenos conhecidos, inclusive Batrachochytrium dendrobatidis $(B d)$, o suposto agente principal de declínios de populações de anfíbios em diversas partes do mundo. Uma vez que as variáveis químicas e físicas de um ecossistema influenciam o crescimento, sobrevivência e atividade metabólica dos microorganismos, a microbiota cutânea que atua como barreira de proteção nos anfíbios contra agente infecciosos, provavelmente é afetada quando determinados parâmetros ecofisiológicos são alterados em ambientes florestais fragmentados, modulando assim a vulnerabilidade das populações de anfíbios aos agentes patogênicos. Nossa pesquisa esteve focada na caracterização das comunidades microbianas residentes da pele dos anfíbios em dois contextos de paisagem: fragmento e área contínua. Os parâmetros utilizados para essas análises foram a densidade microbiana e a riqueza de morfotipos de colônias bacterianas. O potencial inibitório do crescimento de patógenos também foi testado em ensaios do tipo cross-strak. As diferenças de densidade e riqueza microbiana entre as paisagens e a presença de táxons típicos de ambiente, apontam para o ambiente como um componente importante na determinação dos perfis das comunidades microbianas dos anfíbios estudados. Essas mudanças são muito provavelmente consequiências, mas para o entendimento da extensão e natureza de tais consequiências são necessários estudos adicionais. 


\section{Abstract}

The skin of amphibians, as well as that of other animals, acts as a first protection barrier against pathogens. The microbial community resident in the amphibian skin is composed of some species of bacteria that may have antibacterial or antifungal action against known pathogens, including Batrachochytrium dendrobatidis, the alleged principal agent leading to declines of amphibian populations around the world. Because the chemical and physical variables of the landscape influence the growth, survival and metabolic activity of microorganisms, the function of skin as a protective barrier against infectious agents in amphibians, is likely affected by parameters that are altered in fragmented forest habitats. Thus, it is important to understand how environmental conditions affect the skin microbiota of amphibians, and the possible induced changes on vulnerability of amphibians to pathogens. Our research aimed to characterize the microbial communities living skin of amphibians in two contexts of landscape: fragment and continuous area. The parameters used for this analysis were density and richness of microbial morphotypes of bacterial colonies. The potential inhibition of pathogen growth was also evaluated using a cross-streak test, and some taxa in these communities were identified using international protocols. The observed differences in microbial density and richness across landscapes, and the presence of bacterial taxa typical of given environments, point out to the role of environmental change as an important component determining the profiles of microbial communities living on the skin of amphibians. These changes are very likely consequential, but understanding the scope and nature of consequences require additional study. 


\section{Referências Bibliográficas}

Alexander, M.A. \& Eischeid, J.K.E. (2001) Climate variability in regions of amphibian declines. Conservation Biology 15 (4): 930-942.

Amiche, M.; Ladram, A.; Nicolas, P. (2008) A consistent nomenclature of antimicrobial peptides isolated from frogs of the subfamily Phyllomedusinae. Peptides 29 (11): 2074-2082.

Assis, A.B.; Navas, C.A. and Barreto, C.C. (In prep.) Perfis de microbiotas cutâneas em quatro espécies de anfíbios.

Ashcroft, J.W.; Zalinger, Z.B.; Bevier, C.R.; Fekete, F.A. (2007) Antimicrobial properties of two purified skin peptides from the mink frog (Rana septentrionalis) against bacteria isolated from the natural habitat. Comparative Biochemistry and Physiology (Part C):1-6.

Ashcroft, J.W. (2008) Antibacterial properties of skin secretions \& microflora from Eleutherodactylus jonhstonei. A theses submitted in partial fulfillment of the requeriments for the degree of MD/MSc to St George's University Graduate Studies Program. School of Medicine. Department of Microbiology. 111p.

Atlas, R.M. \& Bartha, R.B. (1993). Effects of abiotic factors and environmental extremes on microorganisms. In: Microbial Ecology: Fundamentals and Applications (pp. 212245). The Benjamin/ Cummings Publishing Company, Inc.

Atlas, R.M. \& Bartha, R.B. (1993). Measurement of microbial numbers, biomass, and activities. In: Microbial Ecology: Fundamentals and Applications (pp. 165-211). The Benjamin/ Cummings Publishing Company, Inc.

Austin, R.M. (2000) Cutaneous microbial flora and antibiosis in Plethodon ventralis, p. 127-136. In: The Biology of Plethodontid Salamanders. R.C.Bruce, R.G.Jaeger, and L.D. Houck (eds.). Kluwer Academic/Plenum Publishers, New York.

Barbosa, E.A. (2010) Avaliação da transcrição, expressão e indução de genes que codificam peptídeos antimicrobianos em Hypsiboas raniceps por ferramentas de biologia molecular e espectrometria de massa. Dissertação apresentada ao Instituto de Biologia da Universidade de Brasília como requisito parcial para a obtenção do título de Mestre em Ciências Biológicas. Programa de Pós-graduação em Biologia Molecular. Brasília. 86p.

Becker, C.G (2007) Desconexão de habitats e o declínio global dos anfíbios. Dissertação apresentada ao Instituto de Biologia da Universidade de Campinas como requisito parcial para a obtenção título de Mestre em Ecologia. Programa de Pós-graduação em Ecologia. Campinas. 76p.

Belden, L.K. \& Harris, R.N. (2007) Infectious diseases in wildlife: The community ecology context. Frontiers in Ecology and the Environmental 5(10): 533-539.

Bernardet, J-F \& Bowman, J.P. (2006) The genus Flavobacterium. In: Dworkin, M.; Falkow, S.; Rosenberg, E.; Schleifer, K.; Stackebrandt, E. The prokaryotes. A handbook on the 
biology of bacteria: Proteobacteria: Delta and Epsilon Subclasses. Deeply Rooting Bacteria, Vol. 7. New York, EUA: Springer, 3PªEd. pp. 481-531.

Bernardet, J.; Nakagawa, Y.; Holmes, B. (2002) Proposed minimal standards for describing new taxa of the family Flavobacteriaceae and emended description of the family. International Journal of Systematic and Evolution Microbiology 52: 1049-1070.

Bernardet, J.; Segers, P.; Vacanneyt, M.; Berthe, F.; Kersters, K; Vandamme, P. (1996) Cutting a Gordian Knot: Emended description of the genus Flavobacterium, emended description of the family Flavobacteriaceae, and proposal of Flavobacterium hydatis nom. nov. (Basonym, Cytophaga aquatilis Strohl and Tait 1978). International Journal of Systematic Bacteriology 46 (1): 128-148.

Bertoluci, J. 2005. The São Paulo Leaf-frog Phyllomedusa distincta. Reptilia 43: 66-70.

Bettin, C. \& Greven, H. (1986) Bacteria on the skin of Salamandra salamandra (Amphibia: Urodela) with notes on their possible significance. Zoologischer Anzeiger 216:267-270.

Bevier, C.R.; Sonnevend, A.; Kolodziejek, J.; Nowotny, N.; Nielsen, P.F.; Conlon, J. M. (2004) Purification and characterization on antimicrobial peptides from the skin secretions of the mink frog (Rana septentrionalis). Comparative Biochemistry and Physiology 139:3138. Part C.

Blaustein, A.R. \& Kiesecker, J.M. (2002) Complexity in conservation: lessons from the global decline of amphibian populations. Ecology Letters 5: 597-608.

Birnboim, H. C. \& J. Doly (1979). A rapid alkaline extraction procedure for screening recombinant plasmid DNA. Nucleic Acids Research 7(6): 1513- 1523.

Breed, R.S.; Murray, E.G.D.; Smith, N.R. (1957) Bergey's manual of determinative bacteriology. 7P ${ }^{\mathrm{a}} \mathrm{PEd}$. The Williams \& Wilkins Company. Waverly Press. Baltimore, USA.

Brizzi, R.; Delfino, G.; Pellegrini, R. (2002). Specialized mucous glands and their possible adaptive role in the males of some species of Rana (Amphibia, Anura). Journal of Morphology 254:328-341.

Brucker, R.M.; Harris, R.N.; Schwantes, C.R.; Gallaher, T.N.; Flaherty, D.C.; Lam, B.A.; Minbiole, K.P.C. (2008) Amphibian chemical defense: Antifungal metabolites of the microsymbiont Janthinobacterium lividum on the salamander Plethodon cinereus. Journal of Chemical Ecology 34: 1422-1429.

Campos, F.P. (1994) O Parque Estadual Intervales e o serviço de áreas naturais protegidas. In: Leonel, C. Intervales. Fundação para a conservação e a produção florestal do Estado de São Paulo. São Paulo: A fundação. pp.11-19.

Carey, C. \& Alexander, M. (2003) Climate change and amphibian declines: is there a link? Diversity and Distributions 9:111-121.

Carey, C.; Cohen, N.; Rollins-Smith, L. (1999) Amphibian declines: an immunological perspective. Developmental and Comparative Immunology 23: 459-472. 
Carnaval, A.C.O.Q.; Puschendorf, R.; Peixoto, O.L.; Verdade, V.K.; Rodrigues, M.T. (2006) Amphibian chytrid fungus broadly distributed in the Brazilian Atlantic Rain Forest. EcoHealth 3:41-48.

Christin, M.S.; Ménard, L.; Gendron, A.D.; Ruby, S.; Cyr, D.; Marcogliese, D.J.; Rollins-Smith, L.; Fournier, M. (2004) Effects of agricultural pesticides on the immune system of Xenopus laevis and Rana pipiens. Aquatic Toxicology, 67, 33-43

Conlon, J.M., Kolodziejek, J.; Nowotny, N. (2004). Antimicrobial peptides from ranid frogs: taxonomic and phylogenetic markers and a potential source of new therapeutic agents. Biochemistry Biophysics' Acta 1696: 1-1.

Conlon , J. M.; al-Dhaheri, A.; al-Mutawa, E.; al-Kharrge, R.; Ahmed, E.; Kolodziejek, J.; Nowotny, N.; Nielsen, P.F.; Davidson, C. (2007). Peptide defenses of the cascades frog Rana cascadae: implications for the evolutionary history of frogs of the Amerana species group. Peptides 28:1268-1274.

Culp, C.E.; Falkiniiam III, J.O.; Belden, L.K. (2007) Identification of the natural bacterial microflora on the skin of Eastern newts, Bullfrog tadpoles and Redbacked salamanders. Herpetologica 63 (1): 66-71.

Cushman, S.A. (2006) Effects of habitat loss and fragmentation on amphibians: A review and prospectus. Biological Conservation 128: 231-240.

Daly, J.W. (1995) The chemistry of poisons in amphibian skin. Proceedings of the National Academy of Science of the United States of America 92: 9-13.

Daly, J.; Padgett, W.L.; Saunders, R.L. Cover, J.F. (1997). Absence of tetrodotoxins in a captiveraised riparian frog, Atelopus varius. Toxicon 35 (5) 705-709.

Daszak, P.; Cunningham, A.; Hyatt, A.D. (2001) Anthropogenic environmental change and the emergence of infectious diseases in wildlife. Acta Tropica 78: 103-116.

Densmore, C.L. \& Green, D. E. (2007). Disease of amphibians. Institute for Laboratory Animal Research 48(3): 235-254.

De Vos, P.; Kersters, K.; Falsen, E.; Gillis, M.; Segers, P.; De Ley, J. (1985) Comamonas Davis and Park 1962 gen. Nov., nom. Rev. Emend., and Comamonas terrigena Hugh 1962 sp. Nov., nom. ver. International Journal of Systematic Bacteriology 35(4): 443-453.

DeSantis, T.; Hugenholtz, P.; Brodie, L.; Larsen, N.; Piceno, Y; Phan, R; Andersen, G. (2006). NAST: a multiple sequence alignment server for comparative analysis of $16 \mathrm{~S}$ rRNA genes. Nucleic Acids Research 34:394-9.

DeSantis, T.; Hugenholtz, P.; Larsen, N.; Rojas, M.; Brodie, E.; Keller, K.; Huber, T.; Dalevi, D.; Hu, P.; Andersen, G. (2006) Greengenes, a Chimera-Checked 16S rRNA Gene Database and Workbench Compatible with ARB. Applied Environmental Microbiology (72):5069$72 \mathrm{~T}$.

Ducklow, H.W. \& Mitchell, R. (1979) Bacterial populations and adaptations in the mucus layers on living corals. Limnology and Oceanography 24: 715-725. 
Duellman W.E. \& Trueb L. (1994) Biology of Amphibians. Baltimore/London: Johns Hopkins University Press.

Eaton, A.D.; Clesceri, L.S.; Greenberg, A.E. (1995) Standard methods. For examination of water and wastewater. $19 \mathrm{P}^{\text {th }} \mathrm{P}$ edition. APHA, AWWA, WEF.

Echegaray, J. \& Hernando, A. (2004). Amenazas de los anfíbios. Sustrai 67: 50-52.

Eterovick, P.C.; Carnaval, A.C.O.Q.; Borges-Nojosa, D.M.; Silvano, D.L.; Segalla, M.V.; Sazima, I. (2005) Amphibian declines in Brazil: An overview. Biotropica 37 (2): 166-179.

Evtushenko, L.I. \& Takeuchi, M. (2006) The family Microbacteriaceae. In: Dworkin, M.; Falkow, S.; Rosenberg, E.; Schleifer, K.; Stackebrandt, E. The prokaryotes. A handbook on the biology of bacteria: Archaea. Bacteria: Firmicutes, Actinomycetes. Vol.3. New York, EUA: Springer, 3PªEd. pp: 1020-1098.

Ewing, W.H.; Farmer III, J.J.; Brenner, D.J. (1980) Proposal of Enterobacteriaceae fam. nov. rev. to replace Enterobacteriaceae Rahn 1937, nom. fam. Cons. (Opin. 15, Jud. Comm. 1958), which list standing on nomenclature on 1 January 1980. International Journal of Systematic Bacteriology 30 (4): 674-675.

Felsemburgh, F.A.; Carvalho-e-Silva, S.P.; de Brito-Gitirana, L. (2007) Morphological characterization of the anuram integument of the Proceratophrys and Odontophrynus genera (Amphibia, Anuran, Leptodactylidae). Mícron 38: 439-445.

Fontana, M.F.; Ask, K.A.; MacDonald, R.J.; Carnes, A.M.; Staub, N.L. (2006) Loss of traditional mucous glands and presence of a novel mucus-producing granular gland in the plethodontid salamander Ensatina eschscholtzii. Biological Journal of the Linnean Society 87 (3): 469-477.

Franklin, A.B.; Noon, B.R.; George, T.L. (2002) What is habitat fragmentation? Studies in Avian Biology 25: 20-29.

Funk, W. C. \&; Mills, L. S. (2003) Potential causes of populations declines in forest fragments in an Amazonian frog. Biological Conservation 111: 205-214.

Gallego, V.; García, M.T.; Ventosa, A. (2006) Pedobacter aquatilis sp. nov. isolated from drinking water, and emended description of the genus Pedobacter. International Journal of Systematic and Evolutionary Microbiology 56: 1853-1858.

Garrity, G.M.; Brenner, D.J.; Krieg, N. R.; Staley, J.R. (2005). Bergey's Manual of Systematic Bacteriology. The Proteobacteria. Vol. 2. Part B: The Gammaproteobacteria. EUA. Springer - Verlag, 2P PEd.

Green, S.J.; Michel Jr., F.C; Hadar, Y.; Minz, D. (2007) Contrasting patterns of seed and root colonization by bacteria from the genus Chryseobacterium and from the family Oxalobacteraceae. The International Society for Microbial Ecology Journal $1: 291-299$.

Goodfellow, M. and Maldonado, A. (2006) The families Dietziaceae, Gordoniaceae, Nocardiaceae \& Tsukamurellaceae. In: Dworkin, M.; Falkow, S.; Rosenberg, E.; Schleifer, K.; Stackebrandt, E. The prokaryotes. A handbook on the biology of bacteria: Archaea. 
Bacteria: Firmicutes, Actinomycetes. Vol.3. New York, EUA: Springer, 3Pª̂Pd. pp. 843-888.

Gottlieb, D. (1976) The production and role of antibiotics in soil. The Journal of Antibiotics 29 (10): 987-1000.

Götz, F.; Bannerman, T; Schleifer, K. (2006) The genera Staphylococcus and Macrococcus. In: Dworkin, M.; Falkow, S.; Rosenberg, E.; Schleifer, K.; Stackebrandt, E. The prokaryotes. A handbook on the biology of bacteria: Bacteria, Firmicutes, Cyanobacteria. Vol.4. New York, EUA: Springer, 3Pª PEd. pp. 5-75.

Grimont, P.A.D.; Grimont, F.; Farmer III, J.J.; Asbury, M.A. (1981) Cedecea davisae gen. nov., sp. nov. and Cedecea lapagei sp. nov., new Enterobacteriaceae from clinical specimens. International Journal of Systematic Bacteriology 31(3): 317-326.

Haddad, C.F.B.; Prado, C.P.A. (2005) Reproductive modes in frogs and their unexpected diversity in the Atlantic Forest of Brazil. BioScience 55 (3): 207-217.

Hall, T.A. (1999). BioEdit: a user-friendly biological sequence alignment editor and analysis program for Windows 95/98/NT. Nucleic Acids Symposium 41: 95-98.

Harris, R.N.; James, T.Y.; Lauer, A.; Simon, M.A.; Patel, A. (2006) Amphibian pathogen Batrachochytrium dendrobatidis is inhibited by the cutaneous bacteria of amphibian species. EcoHealth 3: 53-56.

Harris, R.N.; Brucker, R.M.; Walke, J.B.; Becker, M.H.; Schwantes, C.R.; Flaherty, D.C; Lam, B.A.; Woodhams, D.C.; Briggs, C.J.; Vredenburg, V.T.; Minbiole, K.P.C. (2009) Skin microbes on frogs prevent morbidity and mortality caused by a letal skin fungus. The Multidisciplinary Journal of Microbial Ecology (3): 818-824.

Heyer, W.; Heyer, R.; Rand, A.S; Cruz, C.A.G.; Peixoto, O.L. (1988) Decimations, extinctions and colonization of frog populations in southeast Brazil and their evolutionary implications. Biotropica 20 (3): 230-235.

Heyer, W. R.; Rand, A. S.; Cruz, C. A. G.; Peixoto, O. L.; and Nelson, C. E. (1990). Frogs $\quad$ of Boracéia. Arquivos de Zoologia São Paulo 31: 231-410.

IUCN 2010. IUCN Red List of Threatened Species. Version 2010.4. <http://www.iucnredlist.org>. Downloaded on 27 October 2010.

Joly, P.J.; Morand, C.M.; Cohas, A.C. (2003) Habitat fragmentation and amphibian conservation: building a tool for assessing landscape matrix connectivity. Biologies 326: 132-139.

Khammar, N.; Malhautier, L.; Degrange, V.; Lensi, R.;Godon, J.-J; Fanlo, J.-L. (2005) Link between spatial structure of microbial communities and degradation of a complex mixture of volatile organic compounds in peat biofilters. Journal of Applied Microbiology 98: 476490.

Keisecker, J.M.; Blaustein, A.R.; Belden, L.K. (2001). Complex causes of amphibian population declines. Nature 410: 681-683. 
Lam, B.A.; Walke, J.B; Vredenburg, V.T.; Harris, R.N. (2009) Proportion of individuals with antiBatrachochytrium dendrobatidis skin bacteria is associated with population persistence in the frog Rana mucosa. Biological Conservation 143: 529-531.

La Marca, E.; Lips, K.R.; Lötters, S.; Puschendorf, R.; Ibáñez, R.; Rueda-Almonacid, J.V.; Schulte, R.; Marty, C.; Castro, F.; Manzanilla-Puppo, J.; García-Perez, J.; Bolamos, F.; Chaves, G.; Pounds, A.J.; Toral, E.; Young, B.(2005) Catastrophic population declines and extinctions in neotropical Harlequin frogs (Bufonidae: Atelopus). Biotropica 37 (2): 190201.

Lauer, A.; Simon, M.A.; Banning, J.L.; André, E.; Duncan, K.; Harris, R.N. (2007) Common cutaneous bacteria from the Eastern Red-Backed salamander can inhibit pathogenic fungi. Copeia (3): 630-640.

Lauer, A.; Simon, M.A.; Banning, J.L; Lam ,B.A.; Harris, R.N. (2008)P PDiversity of cutaneous bacteria with antifungal activity isolated from female four-toed salamanders. Multidisciplinary Journal of Microbial Ecology 2: 145-157.

Lee, K.; Liu, C.; Anzai, Y; Kim, H.; Aono, T; Oyaizu, H. (2005) The hierarchical system of the 'Alphaproteobacteria': description of Hyphomonadaceae fam. Nov., Xanthobacteraceae fam. nov. and Erythrobacteraceae fam. nov. International Journal of Systematic and Evolutionary Microbiology 55: 1907-1919.

Lips, K.R.; Burrowes, P.A.; Mendelson III , J.R.; Parra-Olea, G. (2005). Amphibian declines in Latin America: Widespread population declines, extinctions and impacts. Biotropica 37 (2): 163-165.

Lips, K.R.; Brem, F.; Brenes, R.; Reeve, J.D.; Alford, R.A.; Voyles, J.; Carey, C.; Livo, L.; Pessier, A. P.; Collins, J.P. (2006) Emerging infectious disease and the loss of biodiversity in a Neotropical amphibian community. Proceedings of the National Academy of Sciences of the United States of America103 (9): 3165-3170.

Lillywhite, H.B. (1974) Amphibian mucous glands: comparative evidence for an adaptive role in preventing cutaneous desiccation. Bulletin of the Ecological Society of America 55: $16 \mathrm{p}$.

Madigan, M. T.; Martinko, J.M.; Parker, J. (2004) Habitats microbianos, ciclos de nutrientes e interações com plantas e animais. In: Microbiologia de Brock. São Paulo: Prentice hall, $10^{\mathrm{a}} \mathrm{Ed}$.

Madigan, M. T.; Martinko, J.M.; Dunlap, P.V.; Clark, D.P. (2009) Microbial growth. In: Brock Biology of Microorganisms. Benjamin-Cummings Publishing Company, $12^{\mathrm{a}} \mathrm{Ed}$.

Mangoni, M.L.; Miele, R.; Renda, T.G.; Barra, D.; Simmaco, M. (2001) The synthesis of antimicrobial peptides in the skin of Rana sculenta is stimulated by microorganisms. The Journal of Federation of American Societies for Experimental Biology 15: 1431-1445.

Mendelson III, J.R.; Lips, K.R.; Diffendorfer, J.E.; Gagliardo, R.W.; Rabb, G.B.; Collins, J.P.; Daszak, P.; Ibáñez, R.D.; Zippel, K.C.; Stuart, S.N.; Gascon, C.Gascon; Silva, H.R.; Burrowes, P.A.; Lacy, R.C.; Bolaños, F.; Coloma, L.A.; Wright, K.M.; Wake, D.B. (2006) Reponding to amphibian loss. Science 314:1541-1542. 
National Center for Biotechnology Information (NCBI). Disponível em: HTUhttp://www.ncbi.nlm.nih.govUTH. Acessado em: 10 de fevereiro de 2008

Navas, C.A. (1996) Implications of microhabitat selection and patterns of activity on the thermal ecology of high elevation neotropical anurans. Oecologia 108: 617-626.

NCBI - National Center for Biotechnology Information (2010). HTUhttp://www.ncbi.nlm.nih.gov/UT

Ogram, A. \& Feng, X. (1997) Methods of soil microbial community analisis. In: Christon J, Hurst, Guy R. Knudsen, Michal J. Mc Inerney, Linda D. Stetzenbach, Michael V. Walter (Eds.) Manual of Environmental Microbiology Washington: American Society for Microbiology. p. 422-430.

Palleroni, N.J. and Bradbury, J.F. (1993) Stenotrophomonas, a new bacterial genus for Xanthomonas maltophilia (Hugh 1980) Swings et al. 1983. International Journal of Systematic Bacteriology 43 (3): 606-609.

Pelczar , M. \&; Reid, R.(1981) Microbiologia Vol II. São Paulo: McGraw-Hill do Brasil.

Plante, A.F. \& Parton, W.J (2007) The dynamics of soil organic matter and nutrient cycling In: Paul, E.A. Soil Microbiology, Ecology and Biochemistry. USA. Elsevier Academic Press. $3^{\mathrm{a}}$ Ed. p. $471-500$

Pombal Jr., J.P. \& Haddad, C.F.B. (2005) Estratégias e modos reprodutivos de anuros (Amphibia) em uma poça permanente na Serra de Paranapiacaba Sudeste do Brasil. Papéis Avulsos de Zoologia 45 (15): 201-213.

Pouds, J. A.; Bustamante, M.R.; Coloma, L.A.; Consuegra, J.A.; Fogden, M.P.L.; Foster, P.N.; La Marca, E.; Masters, K.L.; Merino-Viteri, A.; Puschendorf, R.; Ron, S.R.; SánchezAzofeifa, G.A.; .Still, C.J.; Young, B.E. (2006) Widespread amphibian extinctions from epidemic disease driven by global warming. Nature 439:161-167.

Raffel, T.R.; Rohr, J.R.; Kieseckers, J.M.; Hudson, P.J. (2006) Negative effects of changing temperature on amphibian immunity under field conditions. Functional Ecology 20: 819828.

Reichenbach, H. (2006) The genus Lysobacter. In: Dworkin, M.; Falkow, S.; Rosenberg, E.; Schleifer, K.; Stackebrandt, E. The prokaryotes. A handbook on the biology of bacteria: Proteobacteria:Gamma subclass. Vol. 6. New York, EUA: Springer, 3P ${ }^{\mathrm{a}} \mathrm{PEd}$. pp: 939957.

Rollins-Smith, L.A.; Carey, C.; Longcore, J.; Doersam, J.K.; Boutte, A.; Bruzgal, J.E.; Conlon, J.M. (2002). Activity of antimicrobial skin peptides from ranid frogs against Batrachochytrium dendrobatidis, the chytrid fungus associated with global amphibian declines. Developmental and Comparative Immunology 26: 471-479.

Rollins-Smith, L.A.; Doersam, J.K.; Longcore, J.E.; Taylor, S.K.; Shamblin, J.C.; Carey, C.; Zasloff, M.A. (2002) Antimicrobial peptide defenses against pathogens associated with global amphibian declines. Developmental and Comparative Immunology 26: 63-72. 
Rollins-Smith, L.A.; Reinert, L.K.; O’Leary, C.J.; Houston, L.E.; Woodhams, D.C. (2005) Antimicrobial peptide defenses in amphibian skin. Integrative Comparative Biology 45:137-142.

Sambrock, J.; Fritsch, E.F.; Maniatis, T. (1989) Molecular cloning. A laboratory manual. 2Pª Ed. Could Spring Harbour, New York: Cold Spring Harbor Laboratory Press.

Sanger, F. \& A. R. Coulson (1975). A rapid method for determining sequences in DNA by primed synthesis with DNA polymerase. Journal of Molecular Biology 94(3): 441-448.

Saunders, D.A.; Hobbs, R.J.; Margules, C.R. (1991) Biological consequences of ecosystem fragmentation: a review. Conservation Biology 5(1): 18-32.

Simmaco, M.; Boman, A.; Mangoni, M.L.; Mignogna, G.; Miele, R.; Barra, D.; Boman, H.G. (1997) Effect of glucocorticoids on the synthesis of antimicrobial peptides in amphibian skin. The Journal for Rapid Publication of Short Reports in Molecular Biosciences 416: 273-275.

Slepecky, R.A. and Hemphill, H. E. (2006) The genus Bacillus - Nonmedical. In: Dworkin, M.; Falkow, S.; Rosenberg, E.; Schleifer, K.; Stackebrandt, E. The prokaryotes. A handbook on the biology of bacteria: Bacteria, Firmicutes, Cyanobacteria. Vol.4. New York, EUA: Springer, 3P PEd. pp. 530-562.

Stackebrandt, E. (2006) The family Cellumonadaceae. In: Dworkin, M.; Falkow, S.; Rosenberg, E.; Schleifer, K.; Stackebrandt, E. The prokaryotes. A handbook on the biology of bacteria: Archaea. Bacteria: Firmicutes, Actinomycetes. Vol.3. New York, EUA: Springer, 3P ${ }^{\mathrm{a}}$ PEd. pp. 983-1001.

Steyn, P.L.; Segers, P.; Vancanneyt, M.; Sandra, P.; Kersters, K.; Joubert, J.J. (1998) Classification of heparinolytic bacteria into a new genus, Pedobacter, comprising four species: Pedobacter heparinus comb. Nov., Pedobacter piscium, comb. nov., Pedobacter africanus sp.nov. and Pedobacter saltans sp. Nov. proposal of the family Sphingobacteriaceae fam. nov. International Journal of Systematic Bacteriology 48: 165-177.

Toledo, R.C. \& Jared, C. (1995) Cutaneous granular glands and amphibian venoms. Comparatyve Biochemycal Physiology 111A (1): 1-29.

Towner, K. (2006) The genus Acinetobacter. In:Dworkin, M.; Falkow, S.; Rosenberg, E.; Schleifer, K.; Stackebrandt, E. The prokaryotes. A handbook on the biology of bacteria: Proteobacteria:Gamma subclass. Vol. 6. New York, EUA: Springer, 3PPEd. pp: 746758.

Vos J; Loveren HV; Wester P \& Vethaak D (1989). Toxic effects of environmental chemicals on the immune system. TiPS (10): 289-292.

Weldon, C.; Preez, L.H.; Hyatt, A.D.; Muller, R.; Speare, R. (2004) Origin of the amphibian chytrid fungus. Emerging Infectious Diseases 10(12):2100-2105.

Willems, A.; Ley, J.de; Gillis, M.; Kersters, K. (1991) Comamonadaceae, a new family encompassing the acidovorans rRNA complex, including Variovorax paradoxus gen. nov., comb. Nov., for Alcaligenes paradoxus (Davis, 1969) Journal of Systematic Bacteriology 41 (3): 445-450. 
Woodhams, D.C.; Vredenburg, V.T.; Simon, M.A.; Bilheimer, D.B.; Shakhtour, B.S.; Shyr, Y.; Briggs, C.J.; Rollins-Smith, L. A.; Harris, R.N. (2007) Symbiotic bacteria contribute to innate immune defenses of the threatened mountain yellow-legged frog, Rana mucosa. Biological Conservation 138: 390-398.

Woodhams, D.C.; Alford, R.A.; Maranteli, G. (2003) Emerging disease of amphibian cured by elevated body temperature. Diseases of aquatic 55:65-67.

Zasloff, M. (2002). Antimicrobial peptides of multicellular organisms. Nature 415: 389-395.

Zilli, J.E.; Rumjanek, N.G.; Xavier, G.R.; Coutinho, H.L.C.; Neves, M.C.P. (2003) Diversidade microbiana como indicador de qualidade do solo. Cadernos de Ciência \& Tecnologia 20(3): 391-411.

Zina, J.; Ennser, J.; Pinheiro, S. C. P.; Haddad, C. F. B.; Toledo, L. F. (2007) Taxocenose de anuros de uma mata semidecídua do interior do Estado de São Paulo e comparações com outras taxocenoses do Estado, sudeste do Brasil. Biota Neotropica 7 (2): 49-58.

Xia, S.; Wang, F.; Fu, Y.; Yang, D.; Ma, X. (2005) Biodiversity analysis of microbial community in the chem.-bioflocculation treatment process. Biotechnology and Bioengineering 89 (6): 656-659. 